\title{
ADOLESCENTES E PROFISSIONAIS DE SAÚDE: OLHARES SOBRE A SAÚDE BUCAL
}

\section{VÂNIA CRISTINA MARCELO}

Tese de Doutorado apresentada ao Departamento de Prática de Saúde Pública da Faculdade de Saúde Pública da Universidade de São Paulo para obtenção do Grau de Doutor.

Área de Concentração: Serviços de Saúde Pública

Orientadora: Profa . Dra Isabel Maria Teixeira Bicudo Pereira

São Paulo

2.001 
Autorizo, exclusivamente para fins acadêmicos e cientificos, a reprodução total ou parcial desta tese, por processos fotocopiadores.

\section{Vânia Cristina Marcelo}

Agosto de 2001.

$$
41500 / 2001200
$$




\section{AGRADECIMENTOS}

Profa . Dra. Isabel Maria Teixeira Bicudo Pereira, pela orientação prestada de forma segura, atenciosa, precisa e, acima de tudo, cheia de carinho e amizade de modo a me fazer crescer como estudante e como ser humano;

Dais Gonçalves Rocha, pela capacidade de intercambiar idéias, pela amizade e pela habilidade de estar presente e ausente em momentos muito dificeis;

Regina Stela Marcelo, por ensinar que a vida é muito mais do que imaginamos e pelo exemplo de reconstrução;

Dalva Araújo Marcelo, pelo estímulo constante e por estar presente em toda a minha vida;

Simone Caetano Neves, pela força na transcrição das fitas e na digitação;

Todos os profissionais e adolescentes que tão gentilmente colaboraram e consentiram em doar um pouco de suas vidas para este projeto que inicialmente era apenas individual. 


\section{RESUMO}

\section{MARCELO, V. C. Adolescentes e profissionais de saúde: olhares sobre a}

saúde bucal. São Paulo; 2.001. TTese de Doutorado - Faculdade de Saúde Pública da Universidade de São Paulo]

Análise das percepções e concepções de adolescentes e profissionais da área da saúde sobre a saúde bucal e sua ligação com a vida. Identificam-se as caracteristicas dos adolescentes que procuram uma unidade de saúde pública na cidade de Goiânia-GO para atenção odontológica e suas percepções sobre esta. Apresenta a visão de profissionais que desenvolvem atividades voltadas para adolescentes no que se refere a este grupo populacional, aos serviços desenvolvidos e às possibilidades de atuação futura, com ênfase nas açōes educativas. Foram realizadas entrevistas com adolescentes e profissionais e criadas categorias de análise para seu estudo e apresentação dos resultados. Destacam-se, como conclusões, 0 fato de os adolescentes mostrarem um interesse por sua saúde bucal bem maior que o esperado pelos profissionais e destes apontarem como maior dificuldade para desenvolver ações voltadas para este grupo, a falta de capacitação e treinamento.

\section{DESCRITORES}

Adolescência. adolescentes, saúde, saúde bucal, profissionais, atividades educativas educação, serviços de saúde, odontologia 


\section{SUMMARY}

The present work brings an analysis of the perceptions and conceptions of teenagers and health professionals about oral health and its connection with life. It identifies the characteristics of the teenagers that seek for dental attention in a public health unit in Goiânia-GO as well as their perceptions of it. It also brings the vision of the professionals who work with teenagers about this group, the activities that are developed and the possibilities of future action, emphasizing the educational activities. Interviews were made with teenagers and professionals and categories of analysis were created to study their contents and to present the results. Two of the most significant results are the fact that teenagers show an interest about their oral health much bigger than that expected by the professionals and these point, as the biggest difficulty to develop actions with that group, the lack of capacity and training.

\section{DESCRIPTORES}

Adolescence, teenagers, health, oral health, professionals, educational activities, education, health services, dentistry. 


\section{ÍNDICE}

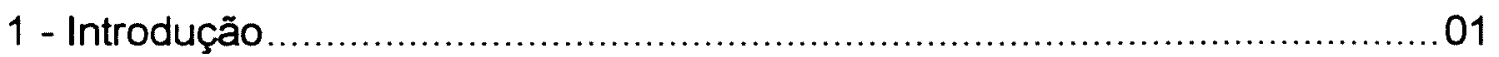

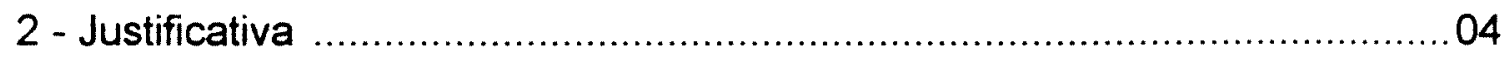

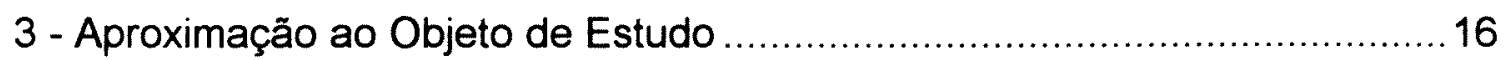

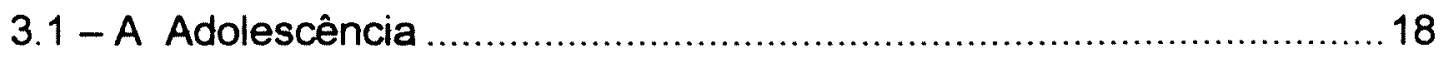

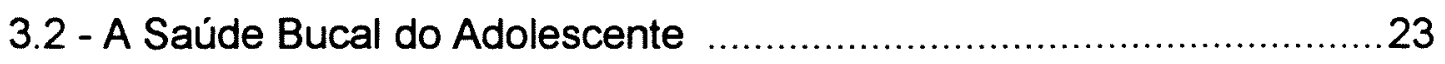

3.3 - Os Serviços Odontológicos e Os Profissionais....................................29

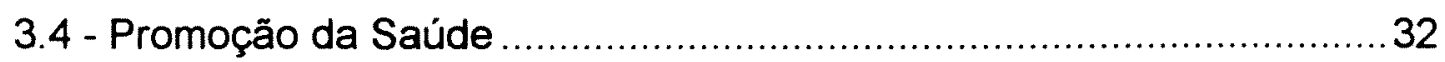

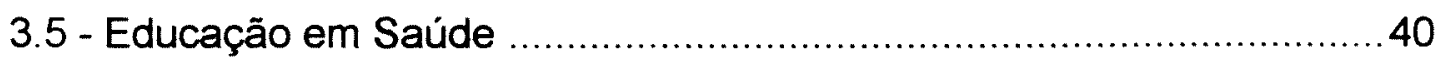

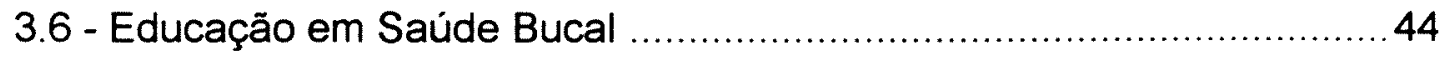

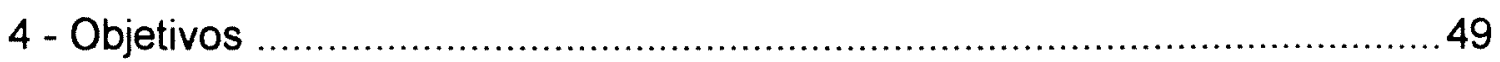

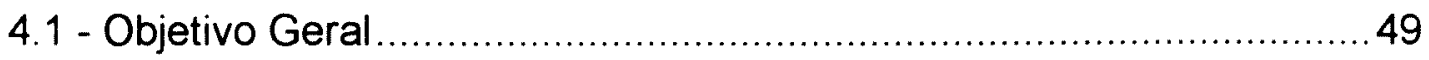

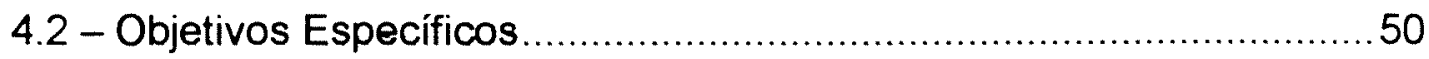

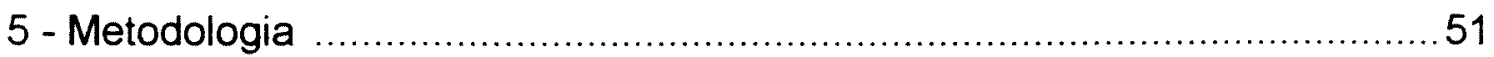


5.1.1 - A Cidade 56

5.1.2 - A Secretaria Municipal de Saúde de Goiânia 61

5.1.3 - O DS Leste, o CAIS das Amendoeiras e o PROLESTE. 63

5.2 - Procedimentos Metodológicos .77

5.2.1 - Levantamento Bibliográfico .78

5.2.2 - Entrevistas .82

5.2.3 - Observações Pessoais .93

5.2.4 - Análise Documental 98

6 - Resultados e Discussão. 100

6.1 - Os Profissionais 102

6.2 - Os Adolescentes do CAIS 150

7 - Conclusões 174

8 - Referências Bibliográficas 180

9- Anexos 


\section{1 - INTRODUÇÃO}

Abordar as áreas de educação e saúde implica sempre procurar abarcar campos extremamente amplos da vida humana que se desenvolvem em relação a aspectos individuais e coletivos e, mais que isso, na relação que estes dois aspectos apresentam, com todos os seus determinantes e resultantes. Trata-se de trabalhar a objetivação e a subjetivação de praticamente todos os elementos que conformam a vida dos indivíduos e das sociedades humanas. Portanto, ao se tentar delimitar um problema ou tema para estudo sistemático dentro destas áreas, sempre se terá que optar por deixar de fora deste estudo aspectos que, certamente, são de fundamental importância, já que seria humanamente impossivel tentar abranger todos eles.

Desse modo, o que se pode fazer é a opção por um recorte desta realidade, ou seja, por uma parcela do todo que seja significativa para quem a estuda e que possa contribuir, dentro de um determinado tema, para a construção do conhecimento a respeito e apontar possibilidades de soluções para os problemas analisados.

Então, optando por trabalhar com uma parcela do todo, o presente estudo trabalha um campo que se mostra radicalmente ligado à educação e à saúde na medida em que determinantes de ambas as áreas se interligam na conformação 
da realidade que está posta e no modo como é sentida, percebida e construida pelos sujeitos envolvidos, isto é, na subjetivação desta realidade.

Assim é que o tema de interesse deste trabalho centra-se nas questões relativas à saúde bucal e, mais especificamente, àquelas relacionadas a uma fase limitada do crescimento e desenvolvimento humano que vem sendo denominada em diferentes contextos de adolescência e pré-adolescência.

$\mathrm{Na}$ busca da compreensão destas questões, buscou-se identificar, neste trabalho, duas percepções vistas como pólos fundamentais neste processo: a do adolescente e a do profissional. Mais que isto, o que se buscou foi também identificar como estas duas percepções se relacionam, o que têm em comum e onde se separam ou se antagonizam. Para tal se trabalhou junto a profissionais da Secretaria Municipal de Saúde de Goiânia-GO (SMS) responsáveis por atividades relacionadas a adolescentes e junto aos próprios adolescentes que procuram este serviço.

Cabe ressaltar que é dado destaque às questões relativas à educação, por se entender que esta, vista em seu sentido mais amplo, se constitui nas bases sobre as quais se estruturam as percepções que os individuos apresentam em relação a sua boca e, a partir da qual estas percepções podem ser desconstruidas e re-construidas cotidianamente, constituindo-se em um privilegiado espaço de produção de valores e hábitos.

Assume-se aqui, sem desconsiderar outros aspectos, que estas percepções desempenham um papel de grande importância na determinação das condições de saúde dos individuos e, por conseguinte, na sua saúde bucal, podendo,

\footnotetext{
Ao ser utilizado o termo "profissional" entenda-se que, neste trabalho, a referência é feita àqueles trabalhadores do serviço de saúde que estão ligados às ações que, de algum modo, envolvem a saúde do adolescente. Estes podem estar no nivel local, lidando diretamente com a população nas unidades de saúde, bem como no nivel central, ocupando posiçōes de técnicos ou cargos de chefia ou decisórios para os serviços relacionados aos adolescentes.
} 
inclusive, se constituir em fatores de mobilização levando à ação ou, opostamente, de paralisia e, conseqüentemente, à inércia e à acomodação.

É a partir destas reflexões que, neste trabalho, leva-se o ponto central de análise para as percepções dos sujeitos envolvidos*. A partir delas buscar-se-á analisar as concepções e sentimentos que determinam a saúde dos indivíduos pesquisados ou, mais especificamente, sua saúde bucal, bem como o tipo de ações ou serviços oferecidos e as perspectivas futuras em relação a este aspecto, já que assume-se que os serviços são um dos elementos fundamentais na rede de interligações que determinam a saúde dos individuos e das populações.

\footnotetext{
Para o caso especifico deste trabalho de pesquisa considerou-se que os "sujeitos envolvidos" eram os profissionais e os adolescentes, embora não se desconsidere o fato de que estes se mostrem em constante relação com vários outros sujeitos que, direta ou indiretamente, influenciam suas vidas.
} 


\section{2 - JUSTIFICATIVA}

Um dos pressupostos deste trabalho é o de que a saúde da população determina e é determinada por diversos fatores que extrapolam e muito a área especifica da saúde, envolvendo todos os campos e setores da vida humana. Sendo a saúde bucal parte inseparável da saúde geral o mesmo pressuposto é admitido. Sabe-se, também, que por razões históricas, culturais e administrativas os serviços de saúde se constituem em um espaço privilegiado para o desenvolvimento de ações promocionais de saúde. Esta é uma das razões pelas quais se optou pelo desenvolvimento desta pesquisa dentro de um serviço específico, a Secretaria Municipal de Saúde de Goiânia (SMS) e, mais especificamente ainda, em uma unidade de saúde que tem em seu planejamento a implantação de um serviço de atenção ao adolescente, o qual deverá incluir ações de saúde bucal. Esta unidade tem a caracteristica de ser considerada uma unidade experimental para projetos desta natureza e tem a pretensão de extrapolar aqueles bem sucedidos para toda a rede da SMS. Este é, também, um dos fatores que demonstram a oportunidade da realização deste trabalho naquele local.

Um grande número de trabalhos na área odontológica têm mostrado que as intervenções, tradicionalmente levadas a cabo em saúde pública, dentro do paradigma cirúrgico-restaurador, escolhido pela profissão odontológica desde a 
sua criação e consolidação enquanto prática profissional, não conseguiram alterar as condições de saúde bucal da população (MURRAY 1992; NADANOVSKY 1994; PINTO 1989a). Apenas em locais onde os esforços se centraram em ações preventivas e promocionais foram conseguidas melhorias significativas nos índices epidemiológicos de modo geral. Estas ações têm seu êxito grandemente vinculado a ações educativas.

Com os recentes avanços na adoção de medidas preventivas de larga escala, como a fluoretação das águas de abastecimento e pastas dentais, a odontologia brasileira tem comemorado, nos últimos anos, um maior controle da principal patologia bucal que é a cárie dental. A perspectiva que se tem nesta área, é a de que, na medida em que se consegue o controle desta afecção, cada vez melhorem mais as condições de saúde bucal das novas gerações.

QUADRO 1 - Comparação entre indices de cárie na faixa etária de 7 a 14 anos, no Brasil, zona urbana, com a redução percentual, entre os anos de 1986 e 1993.

\begin{tabular}{|c|c|c|c|}
\hline \multirow{2}{*}{$\begin{array}{c}\text { IDADE } \\
\text { (anos) }\end{array}$} & \multicolumn{2}{|c|}{ CPO-D MEDIO } & $\begin{array}{c}\text { REDUÇĀO } \\
\text { (\%) }\end{array}$ \\
\cline { 2 - 3 } & $\mathbf{1 9 8 6}$ & $\mathbf{1 9 9 3}$ & 35,653 \\
8 & 1,945 & 1,271 & 27,600 \\
9 & 2,529 & 1,831 & 29,422 \\
10 & 3,375 & 2,382 & 34,389 \\
11 & 4,516 & 2,963 & 35,859 \\
12 & 5,767 & 3,699 & 27,484 \\
13 & 6,673 & 4,839 & 29,326 \\
14 & 7,802 & 5,514 & 24,476 \\
\hline
\end{tabular}

Fonte: PINTO 1997.

Fundamentado nos dados do quadro acima exposto (quadro 1), PINTO (1997) afirma que: "Há uma diminuição consistente na prevalência de cánie em 
todas as idades, significando um ganho conjunto no país para esse grupo etáno da ordem de $30,5 \%$."

FREIRE et al (1995), num estudo sobre a prevalência de cárie e necessidade de tratamento em escolares de Goiânia no ano de 1994, relata uma redução de 45\% em relação ao índice CPO-D" nacional e 56,7\% em relação ao da região Centro-Oeste registrado no levantamento nacional de 1986 (quadro 2).

QUADRO 2 - Índice CPO-D encontrado em estudos de 1986 e 1994 e percentual de redução no periodo comparando Goiânia com o Brasil e a região Centro-Oeste.

\begin{tabular}{|l|c|c|c|c|c|}
\hline \multicolumn{3}{|c|}{1986} & 1994 & \multicolumn{2}{c|}{ Redução om \% } \\
\hline Idade & Brasil & $\begin{array}{c}\text { Contro- } \\
\text { Oesto }\end{array}$ & Goiânia & Brasil & $\begin{array}{c}\text { Contro- } \\
\text { Oesto }\end{array}$ \\
\hline 6 a 12 anos & 4,02 & 5,09 & 2,21 & 45,02 & 56,58 \\
\hline 12 anos & 6,65 & 8,52 & 4,50 & 32,33 & 47,18 \\
\hline
\end{tabular}

Fontes : BRASIL 1988 e FREIRE et al 1995.

NARVAI em 1996, apresentando os resultados preliminares de uma pesquisa sobre a prevalência de cárie dentária em crianças da cidade de São Paulo, afirma que o índice CPO-D encontrado aos 12 anos de idade foi de 2,3 para escolas públicas e de 1,7 para as escolas particulares. Comparando com o levantamento de 1986, "a queda neste periodo de 10 anos varia de $65 \%$ entre crianças de escolas públicas a $74 \%$ nas escolas privadas."

Por ocasião do ano da Saúde Bucal, instituído pela Organização Mundial de Saúde (OMS), em 1994, a Unidade de Saúde Bucal desta organização, no estudo sobre "O mundo e a cárie: uma situação de contrastes", afirma que o estágio atual

CPO-D é o índice mais utilizado em odontologia para medir prevalência de cárie dentária, apontando a história de cárie dos elementos dentais, sendo que a sigla traduz dados sobre presença de Cárie, Perda de dente por cárie e Obturações por elemento Dental. 
do conhecimento odontológico "é suficiente para controlar, se não eliminar, cárie dental."

Sabe-se que o acesso aos serviços ou à atenção odontológica pode influenciar na melhoria das condiçōes gerais da boca de uma pessoa e que este acesso no Brasil é determinado por condicionantes econômicos, tendo em vista os altos preços das clínicas privadas e a baixa cobertura e resolutividade da maioria dos serviços públicos. Por outro lado, cabe ressaltar que também já é conhecido o fato de que a oferta de serviços odontológicos exclusivamente curativos disponiveis em uma comunidade ou região, não guarda ligação direta com as condições de saúde bucal da população ali residente. Do mesmo modo já foi demonstrado que a análise da riqueza de uma região ou de um pais, ou por outro lado, sua pobreza, quando tomadas isoladamente, não podem ser diretamente relacionadas aos principais índices de saúde bucal (PINTO 1989a).

NADANOVSKY (1994), analisando a redução dos índices de cárie dentária no decorrer dos últimos anos em vários países industrializados, bem como a oferta ou disponibilidade de serviços curativos, afirma que:

"(..) a principal razão desse declínio recai sobre o largo uso de fluoretos, especialmente nas pastas de dente. Outras possiveis razões são as mudanças nos critérios de diagnóstico, no padrão de consumo de açúcar, amplo uso de antibióticos, melhoria na higiene oral e uma variação cíclica natural. Esses fatores parecem ter exercido maior influência na redução da prevalência da cárie dentária do que os tratamentos odontológicos.

PINTO (1996), em um amplo estudo sobre os indices de cárie no Brasil e no mundo, comparou dados de 165 paises incluindo todos os continentes. Concluiu que os dez paises com mais alto padrão de desenvolvimento humano*

\footnotetext{
- Neste estudo o autor utilizou o Índice de Desenvolvimento Humano - IDH -, produzido pela Organização das Nações Unidas (ONU) através do Programa das Nações Unidas para o Desenvolvimento (PNUD), que é uma medida composta que inclui três dimensões igualmente
} 
(pela ordem: Canadá, Estados Unidos da América, Japão, Holanda, Finlândia, Islândia, Noruega, França, Espanha e Suécia) possuem um CPO-D médio aos 12 anos de 2,54, enquanto que os dez piores (Níger, Serra Leoa, Mali, Etiópia, Afeganistão, Burquina Faso, Moçambique, Somália, Burundi e Angola) apresentam um CPO-D de apenas 1,76. Da mesma forma, os dez países com o maior Produto Nacional Bruto per capita têm um indice médio de 2,85 contra somente 1,32 dos dez menores.

Considerando os resultados deste estudo de 1996 e um outro do mesmo autor publicado em 1990 observa-se que o CPO-D global sofreu um declínio de aproximadamente $15,5 \%$, enquanto no Brasil essa queda atingiu $27 \%$ no índice CPO-D aos 12 anos.

O exposto demonstra que as medidas preventivas que vêm sendo adotadas têm surtido efeito positivo, porém ainda timido se considerarmos as necessidades da nossa população e se considerarmos que, ainda hoje, a cárie dental com suas conseqüências pode ser responsabilizada pelo maior volume de necessidades de atenção na área, apesar de ser uma doença perfeitamente prevenível.

Em paises onde essa doença já está sob um maior controle, as atenções já podem se voltar para as periodontopatias e problemas ortodônticos, aspectos anteriormente considerados secundários em relação à cárie dentária. Esse controle da principal doença bucal vem permitir que os "olhos" da odontologia se desloquem um pouco de foco, possibilitando que a saúde bucal possa ser vista de uma forma mais integrada à saúde geral do indivíduo e da coletividade. Problemas como maloclusão, mastigação e deglutição atípicas, alterações da fala, assimetrias faciais, hábitos deletérios e câncer passam a ser trabalhados não apenas como objetos de uma especialidade, mas como questões que perpassam toda a vida do individuo e estão relacionadas a áreas aparentemente tão distintas 
quanto a psicologia, fisioterapia, fonoaudiologia, otorrino-laringologia, nutrição além da própria odontologia.

As quedas nos indices de cárie observadas em diferentes locais têm sido atribuídas a adoção intensiva de medidas preventivas de larga escala como fluoretação da água de abastecimento, adição de fluoretos às pastas dentais e ampliação de programas de aplicação tópica de fluoretos, especialmente para escolares (BELLINI 1991).

Quanto às demais medidas preventivas que incluem controle de dieta e melhoria das técnicas de higiene oral, ainda não se tem noticia de mudanças significativas das práticas adotadas pela população. (MURRAY 1992)

Por outro lado é sabido que programas e/ou medidas educativas, com maior ou menor grau de sucesso, têm sido implantados em diversos momentos e regiões brasileiras. Contudo, são ainda muito poucos os trabalhos que avaliam a efetividade desses programas ou medidas (ROCHA e BICUDO PEREIRA 1994)e, portanto, torna-se muito difícil saber em que medida estas podem ser responsabilizadas pelas mudanças ocorridas ou não no quadro epidemiológico da saúde bucal.

Para explicar os principais fatores aos quais poder-se-ia atribuir a redução dos indices de cárie NARVAI (1994) aponta:

1- fluoretação das águas de abastecimento público;

2- dentifrícios fluoretados no Brasil;

3- programas preventivos.

A universalização do uso do flúor, com ou sem a cooperação consciente dos individuos, tem realmente sido eficaz no combate à cárie; no entanto, esse processo que vem trazendo o benefício do controle desta afecção bucal traz 
também, como contrapartida, uma realidade desconcertante para a profissão odontológica: quanto mais os dentes permanecem na boca, mais aumenta a probabilidade da ocorrência das periodontopatias e maloclusões quando não se consegue a manutenção de hábitos saudáveis por parte das pessoas.

Cabe ressaltar que ainda não se conhecem possibilidades de enfrentar estes problemas bucais através de ações coletivas de grande impacto que sejam, de certa forma, independentes de atos volitivos de cada indivíduo, como é o caso da fluoretação das águas. Particularmente as periodontopatias têm suas soluções grandemente dependentes de ações individuais regulares, as quais requerem um suporte muito maior das açס̄es educativas para serem conduzidas eficazmente.

Nos serviços públicos odontológicos que apresentam propostas de açōes educativas, estas se concentram, em sua quase totalidade, em atividades relacionadas às crianças até 12 anos de idade (principalmente escolares) e às mães ou gestantes, vistas como grupo determinante das condiçōes de saúde de seus filhos (ROCHA 1997).

A odontologia brasileira tem mostrado que, quando propõe programas e ações preventivas e/ou educativas para outros segmentos populacionais que não as crianças em idade escolar, tende a deslocar seu foco de atenção para as faixas etárias mais precoces, depositando, nos dias atuais, grande ênfase na odontologia para bebês e até mesmo na chamada odontologia intra-uterina (ANDRADE 1997; WALTER 1991). Sem diminuir de modo algum a importância de trabalhos direcionados para estes grupos, nota-se, no entanto, que têm sido muito poucos os trabalhos voltados para o adulto, o trabalhador ou para o adolescente. Pensar um pouco mais nestes segmentos é levar em consideração duas das bases do Sistema Único de Saúde (SUS) - a integralidade e a universalização das ações, as quais não têm sido contempladas, a despeito dos inegáveis avanços que a odontologia vem alcançando. 
Mesmo considerando o peso que medidas preventivas de larga escala em odontologia têm na determinação dos índices de prevalência de alguns problemas bucais, estas não podem, sozinhas, resolver todos os problemas de saúde bucal." É necessária a adoção de outras medidas (promocionais, preventivas individuais, curativas e de reabilitação) que dependem grandemente da aderência“" dos usuários. Naturalmente esta aderência é grandemente dificultada quando se tenta implantar tais medidas impondo-as. É de fundamental importância a participação de todos os envolvidos no processo que vai desde a escolha até a execução destas medidas. $E$ se isso é verdade para a população de modo geral, mais ainda o é para o grupo populacional formado por indivíduos em uma fase tão rica e delicada como é a adolescência. Esta aderência pode ser maior ou menor dependendo do processo educativo desenvolvido junto a essa população.

Os dados epidemiológicos disponíveis no Brasil, bem como estudos realizados em paises industrializados, onde a cárie vem sendo controlada, sugerem que o foco das preocupações da odontologia deve começar a se deslocar em dois sentidos.

O primeiro deslocamento que se pode visualizar é no sentido da necessidade de ação om idades mais avançadas que aquelas nas quais a odontologia vem intervindo com mais ênfase. Desde a década de 50 , com a implantação do Sistema Incremental' no Brasil, grande parte das ações, particularmente as educativas e curativas, têm sido focadas em crianças de 6-12 anos, especialmente escolares. Com a manutenção da integridade dental ou

\footnotetext{
- Assume-se que é possivel e necessário não conceber de forma dicotomizada as ações curativas e preventivas quando se tem uma pretensão de resolver os problemas de saúde da população. Ambas abordagens - curativa e preventiva, desempenham um papel importante, especifico e complementar no processo saúde-doença. Como tal pode-se considerar a possibilidade da ênfase ser preventiva, mas é sempre necessário garantir o acesso da população à integralidade das ações (promoção, educação, prevenção, cura e reabilitação).

“Entende-se por "aderência" a possibilidade de indivíduos ou grupos assumirem a execução total ou parcial de ações relativas a uma determinada proposta ou programa.

-.* Para maiores detalhes sobre o Sistema Incremental ver o capítulo VIII de CHAVES, 1977 e o item 4.1 de PINTO 1989a.
} 
simplesmente com a manutenção do elemento dental, pode-se esperar que estes venham a requerer maior atenção odontológica que aquela dispensada quando estes dentes eram perdidos muito precocemente. Muitos adultos que perderiam seus dentes precocemente passam a mantê-los e isto significa um aumento na demanda por atenção em faixas etárias mais avançadas.

Além disso, um outro aspecto que cabe ressaltar, este ainda mais estreitamente relacionado ao processo educativo da população, diz respeito aos valores que diferentes grupos populacionais mantém. BELLINI (1991) analisando o caso da Nova Zelândia, país que garantiu o acesso de toda a sua população jovem ao tratamento odontológico curativo, relata um fato muito interessante:

"A Nova Zelândia, através de uma inovação em seu sistema de saúde bucal, na década de 60, passou a garantir a todas as crianças, até a idade de 16 anos, um controle de cárie a tal nivel que todas as cavidades eram diagnosticadas e restauradas precocemente. Sua população infantil, no final dos anos 70, após 20 anos nesse sistema, atingira os 16 anos com o maior indice possivel de dentes presentes na boca e sem cáries abertas. Porém, aos 30 anos, esta população começava a perder dentes tanto quanto a população de outros paises. O simples tratamento das lesões, oferecido 'gratuitamente' sem responsabilidade nenhuma para quem o recebe, não levou a nenhuma valonização dos dentes saudáveis por muitos, quando adultos. Especula-se mesmo, que muitos neo-zelandezes decidem por extrair seus dentes em idades precoces simplesmente porque não os valonizam suficientemente. O programa foi demasiadamente patemalista e não formou uma mentalidade preocupada com a saúde bucal."

O segundo dos deslocamentos referidos diz respeito à classificação, já tradicional para a odontologia, que aponta os problemas de saúde bucal obedecendo à seguinte ordem de importância, (considerando, inclusive, sua prevalência): $1^{\circ}$ - cárie dental; $2^{\circ}$ - periodontopatias; $3^{\circ}$ - maloclusões; $4^{\circ}$ - fendas 
palatinas; $5^{\circ}$ - câncer bucal (CHAVES 1977). É evidente que, se for conseguida a diminuição significativa dos índices de cárie dental, a maior demanda por atenção deve se deslocar para as periodontopatias e maloclusões.

Com efeito, NEDER e MANFREDINI (1997), citando alguns dados relevantes de uma pesquisa conduzida pela Faculdade de Saúde Pública da USP e pela Secretaria de Estado da Saúde junto a escolares da cidade de São Paulo, afirmam:

"O levantamento também aponta que, muito embora a cáne tenha sido reduzida, outros problemas persistem. O fato de que $40 \%$ das crianças tenham má-oclusão (problema de articulação da arcada dentána) moderada ou severa, deve servir de estimulo para que as autoridades sanitánias organizem novos senviços de ortodontia, para fomecer aparelhos gratuitos às crianças. A constataçáo de que a fluorose dentária foi identificada em pequenos percentuais alerta para que os poderes públicos assumam a necessidade de se discutir a proibição da comercialização de medicamentos que contenham fluoreto de sódio na forma de comprimidos ou gotas na cidade e que a Cámara Municipal de São Paulo aprove o projeto de lei que impede a venda de água com alto teor de flúor."

Os atuais adolescentes não puderam usufruir de modo integral dos beneficios das açōes preventivas em larga escala que vêm alterando as condiçōes de saúde bucal. Estas medidas só foram estendidas à maior parte da população a partir do início da década de 1990. Apesar destes sujeitos, atuais adolescentes, ainda apresentarem alta demanda por atendimento clínico aos problemas relativos à cárie dental, são exatamente eles mesmos que podem dar as pistas mais interessantes no sentido de identificar a forma como lidam com sua boca, e, portanto, orientar como os serviços devem ser planejados para atendê-los de forma mais adequada, pensando não só a curto, mas também a longo e médio prazo. 
É nesta fase que, por questões biológicas ligadas à puberdade, agravam-se os problemas periodontais, segundo "grande vilão" na odontologia. Estes problemas só podem ser prevenidos através de medidas que necessitam da ação direta de seus portadores, como, por exemplo, a adequada higienização bucal.

A adolescência, que é uma fase em que a socialização dos individuos desempenha papel preponderante em suas vidas, tem sido tratada de maneira muito superficial ou mesmo esquecida pelos serviços de saúde de modo geral, não só os odontológicos. AYRES e FRANÇA Jr. (1996) afirmam que: "Não são comuns serviços de saúde que dispõem de trabalho voltado especificamente para a população adolescente, com suas necessidades particulares e seu modo todo peculiar de procurar e utilizar a assistência à saúde." Esta mostra ser uma verdade ainda mais evidente quando se trata de serviços odontológicos. Sendo a adolescência uma etapa que vai determinar decisivamente as condições de saúde bucal para o resto da vida dos indivíduos, condições estas que influem marcadamente na forma com que estes individuos se inserem na sociedade, cumpre tentar descobrir que fatores poderiam ser apontados no sentido de ampliar ou melhorar a atuação dos serviços odontológicos em relação a estes individuos.

Mesmo naqueles serviços que apresentam atividades voltadas para este grupo populacional surge uma questão que precisa ser pensada mais a fundo, buscando um salto qualitativo. Esta questão é abordada por AYRES (1996), analisando os serviços de saúde de modo geral, da seguinte forma:

"Um dos maiores obstáculos a qualquer trabalho preventivo com populações de crianças e adolescentes parece ser a forma estereotipada e naturalizada com que temos tratado os jovens em nossos serviços de educação e saúde, especialmente os adolescentes.(..)

Com efeito, esses grupamentos sociais particulares não têm chegado a travar, com os serviços e programas encarregados de cuidar de sua educação $e$ 
saúde, senão um contato bastante superficial. Esses contatos estão longe de realizar o profundo diálogo que precisa ser estabelecido entre estes jovens e os serviços para tomá-los mais aptos a implementarem sua proteção contra abuso de drogas, as DSTs e a AIDS, contendo a disseminação destes problemas. (...)"

É justamente na tentativa de superar esta visão "estereotipada e naturalizada", buscando formas pelas quais os serviços possam dar uma maior e/ou melhor resposta às necessidades desta fase, que a investigação, neste estudo, é proposta a partir dos dois sujeitos básicos desta relação: os próprios adolescentes e os profissionais destes serviços.

Assim é que este trabalho teve como propósito responder algumas perguntas relativas às concepções destes sujeitos no que se refere à própria adolescência, à saúde bucal e aos serviços odontológicos, já que é a partir destes dois grupos e de sua relação que se determinará a forma de funcionamento destes serviços. 


\section{3 - APROXIMAÇÃO AO OBJETO DE ESTUDO}

Aqueles que se propõem a trabalhar com o tema aqui proposto, já nas leituras e reflexões iniciais podem perceber a sua alta complexidade. $O$ objeto escolhido para estudo - as percepções de profissionais e adolescentes sobre a própria adolescência, sua saúde, incluindo a saúde bucal e as possibilidades dos serviços, particularmente no que se refere ao processo educativo neste campo não se constitui em algo inerte ou estático. Apresenta constantes transformações e mostra-se em plena construção. Aparecem mesmo muitas discordâncias quanto à própria natureza e essência da adolescência. Pode-se perceber logo às primeiras leituras, que vários aspectos requerem ainda muitos estudos, encontrando-se mais interrogações que respostas. Outros aspectos apresentamse relativizados, ficando explícito o caráter subjetivo das análises.

Isto, longe de desencorajar a entrada neste campo de pesquisas, só vem a confirmar a necessidade de avançar, buscando-se, inclusive, mais dados empíricos que possam ajudar a decifrar o que agora se apresenta como enigma.

Não se pretende, neste caminhar, uma neutralidade ou isenção frente ao objeto deste estudo. Ao contrário, o que se quer é uma aproximação maior, encontrando-se possibilidades de desvelamento do que hoje se apresenta de forma bastante nebulosa. Está bastante claro que o olhar que se lança sobre o 
objeto sofre todas as influências contextuais e históricas de quem o lança, na mesma medida em que este objeto é moldado por influências da mesma natureza, intrinsecas a ele.

O que se busca neste capítulo é a explicitação dos conceitos e concepções* que norteiam a condução deste trabalho, sobretudo no que se refere aos aspectos relativos à concepção de adolescente, sua saúde, incluindo a saúde bucal, os serviços odontológicos e suas possibilidades de execução, a promoção da saúde e os limites e perspectivas para a prática da educação em saúde, e, especificando ainda mais, da educação em saúde bucal.

\footnotetext{
- Entende-se por conceito a representação de um objeto por meio de suas características gerais, sendo este conceito adquirido a partir de pensamentos, idéias ou opiniões alheias ao indivíduo O termo concepção, por outro lado, refere-se a algo criado ou formulado pelo próprio indivíduo de maneira original.
} 


\section{1 - A ADOLESCÊNCIA}

Embora a palavra adolescente seja bastante corriqueira no cotidiano brasileiro, as concepções que dão suporte ao termo são bastante variadas. $\mathrm{O}$ Ministério da Saúde, em documento de 1989 que trata das bases programáticas para a saúde do adolescente, define adolescência da seguinte forma:

"A adolescência, faixa etánia entre 10 e 19 anos, é o período de vida caracterizado por intenso crescimento e desenvolvimento, que se manifesta por transformações anatômicas, fisiológicas, psicológicas e sociais."

Esta conceituação define com bastante precisão os limites etários deste período, determinando inclusive qual é o periodo da vida que deve ser caracterizado por "intenso crescimento e desenvolvimento". Desta forma destaca o papel da natureza sobre este processo ao mesmo tempo que o universaliza, limitando as possibilidades de variações individuais ou de diferentes grupos sociais. Lendo este conceito parece não haver grandes diferenças entre os processos vividos, por exemplo, por um menino que trabalha desde os 6 ou 7 anos como carvoeiro nas fazendas do interior do Brasil e nunca freqüentou escola e um outro que nesta mesma idade começou a estudar em uma escola de um bairro nobre de uma grande cidade. PERES (1995), denunciando a forma 
equivocada que se tem tratado o tema, comenta sobre a necessidade de se pensar mais sobre o que é a adolescência. Esta autora afirma que:

“Esta é uma questão que costuma ficar 'no limbo', em temos de literatura, não no sentido voluntário, premeditado, mas porque, acreditamos, saivo engano, poucos pararam para refletir a respeito. E ao não fazê-lo, não explicitá10, em muitos momentos, tende-se a reduzir a compreensão da adolescência ao que se observa em determinados adolescentes, generalizando o obsenado em seres particulares, singulares, ao universo dos adolescentes e, destes à concepção de adolescência. Tais generalizações, de um lado, levam muitos a 'naturalizarem' o processo da adolescência e, desta feita, dificultando identificar diferenças e desigualdades em adolescentes concretos, por outro lado, a realidade, não correspondendo a tais generalizações, pelo fato de não constituir um único bloco homogêneo, ao contrário, ser constitutivamente heterogênea, eivada de contradições, desigualdades e diferenças, leva outros até a possibilidade extrema de questionarem a própria existência do processo, pelo menos em alguns grupos sociais ou em culturas especificas, no sentido instituido."

Ainda abordando as diferentes formas possíveis de se viver a adolescência nos dias de hoje, CHUBB et al (1997), em estudo conduzido nos Estados Unidos, tratam da polêmica teórica existente nos dias atuais naquele país sobre as definições de adolescência e as diferentes formas de se passar por este período. Abordam o fato de que esta não é necessariamente uma fase traumática e de turbulências.

Segundo CAVALCANTTI (1988) a adolescência é a fase de crescimento biopsicossocial que vai da infância à idade adulta. O "crescer" para que seja uma experiência equilibrada de vida, deve implicar num crescimento solidário biológico, sócio-cultural e psicológico (ELIAS 2000). 
A Organização Pan-Americana da Saúde (OPAS) no seu Manual Para a Educação em Saúde Integral do Adolescente (1996), utilizando linguagem dirigida diretamente para este, conceitua a adolescência do seguinte modo:

"A adolescência tem sido a etapa da vida em que experimentaste o mais rápido processo de crescimento físico e maturação emocional e intelectual. Este desenvolvimento incluiu câmbios físicos, emocionais e sociais. Do mesmo modo se produz uma vaniação na maneira como te relacionas com o mundo que te rodeia.

Este período que se inicia com a puberdade ou o começo da idade fértil tem sido rodeado de rituais, desde que temos conhecimento da história do homem, nos quais se reconhece aberta ou tacitamente o começo da capacidade reprodutiva. Atualmente estas cenimônias se traduzem, em algumas culturas, em uma festiva recepção de boas-vindas a um novo membro ativo da sociedade e, em outras, no começo da vida laboral ou da independência e exclusão da vida familiar. (...) A adolescência se caracteriza por câmbios físicos e psicológicos em cada sexo."

Nota-se nos dois conceitos acima o forte componente dos fatores biológicos como determinantes de grandes e profundas transformações nos demais âmbitos da vida. Neste último, nota-se uma afirmação no minimo questionável, especialmente por ser diretamente dirigida aos próprios adolescentes, sobre “a etapa da vida em que experimentaste o mais rápido processo de crescimento físico e maturação emocional e intelectual"; vários estudos e mesmo a observação empírica mostram que nenhuma etapa da vida se compara aos primeiros meses em termos de quantidade e velocidade de transformação. É também interessante esta associação tão diretamente feita entre 0 inicio desta etapa com marcos biológicos como a "a puberdade ou o começo da idade fértil" ou ainda com o reconhecimento "aberta ou tacitamente" do "começo da capacidade reprodutiva". Outra vez não são levadas em consideração as marcantes diferenças de gênero,

Original em espanhol. 
classe social, contexto sócio-cultural, etnia e meio ambiente, apenas citando alguns dos fatores intervenientes neste processo.

DOMINGUES (1997), tratando da "modernização" dos costumes como fator determinante da multiplicação das oportunidades e ambientes para novas vivências, chama a atenção para o fato de que "estas possibilidades são ainda cercadas de limites e determinações para os adolescentes havendo, inclusive diferenças de gênero para a definição das relações", alertando que para a mulher adolescente essas limitações continuam sendo maiores. Estas observações são corroboradas por REIS e ZIONI (1993), para os quais "haveria algo de inadequado no conceito de adolescência quando aplicado indistintamente ao universo geral dos gêneros masculino e feminino." Estes autores lembram o papel histórico do exército e da escola como instituições socializadoras dos indivíduos e a forma como estas duas instituições tratam diferentemente homens e mulheres, sendo que até recentemente estas se encontravam excluídas de ambas.

\section{Ainda para DOMINGUES (1997):}

"Assim, ao invés de se tomar o fenômeno da adolescência no mundo atual como substantivamente diferente, dadas as transformações sócio-econômicoculturais por que passa a humanidade, a tendência observada por parte da sociedade é a de uma visão funcionalista e a-histórica, portanto, interpretando o comportamento adolescente sob parâmetros e valores tradicionais, onde o diferente e novo muitas vezes são conotados como desviantes, necessitando controle social."

Tais afirmações podem levar a reflexões no sentido da necessidade de se pensar em formas de escutar estes adolescentes como sujeitos concretos, inseridos em uma sociedade que os molda, mas que também é moldada por eles. Individuos com capacidade para observar o mundo que os cerca, pensar sobre ele, propor transformações e trabalhar no sentido de alcançá-las. 
Embora não se possa concordar com uma limitação unicamente etária, ou de função social, ou biológica ou qualquer outra usada de modo único para caracterizar a adolescência enquanto processo e etapa de vida, torna-se necessário pensar em alguma forma viável de limitar a possibilidade de inclusão de sujeitos nos limites desta pesquisa.

Por esta razão foram escolhidas duas características como necessárias para a inclusão dos indivíduos no grupo sujeito desta pesquisa. A primeira foi a procura dos próprios sujeitos pelos serviços de atenção em saúde bucal em uma unidade da SMS. A segunda característica foi a de que este individuo deveria ser considerado pelo próprio serviço como "adolescente" e isso é traduzido, no caso específico da SMS, pela idade, tendo em vista que abaixo de 12 anos são considerados como crianças e incluídos nos programas deste grupo e, somente com 18 anos ou mais passam a ser tratados com o status de adultos, inclusive podendo se responsabilizar pelas decisões que devem ser tomadas para seu atendimento.

Assim, para efeito desta pesquisa, ao se fazer referência ao adolescente, entende-se que estaremos tratando do jovem entre 12 e 17 anos de idade que procura os serviços. No entanto, é preciso repetir, isto não significa que a visão que se tem de adolescência seja condicionada unicamente à idade cronológica dos indivíduos e sim a um conjunto de características destes que assinalam a passagem da infância à fase adulta. Portanto, muito embora seja freqüente considerar que o processo do "adolescer" se inicia com a puberdade e se alonga até os 19 anos, não podem ser desconsiderados os fatores psicológicos, sociais e culturais intervenientes neste processo, o que gera a compreensão de que a adolescência pode se entender por um período bem mais longo ou, ao contrário, bem mais curto. 


\section{2 - A SAÚDE BUCAL DO ADOLESCENTE}

Entre os objetos de estudos epidemiológicos mais abrangentes na área odontológica, a saúde bucal do adolescente certamente não tem se mostrado como um dos mais estudados. A maior parte dos estudos toma por base a idade de 12 anos e pesquisam o indice CPO-D. Várias publicações comprovam que, em diversas cidades do Brasil, os indivíduos têm chegado à idade de 12 anos com um número bem menor de dentes atacados pela cárie, tendência esta já bastante documentada em paises industrializados desde a década de 1970. As poucas publicações referentes a estudos que incluem grupos de adolescentes no Brasil limitam-se, em sua maioria, a dados mais genéricos, associados à faixa etária de 15 -19 anos ou à idade de 18 anos, usada como indicador. O período de vida compreendido entre os 12 e os 14 anos não costuma ser estudado e mesmo a faixa de 15 -19 costuma aparecer como um bloco compacto e homogêneo. Sem dúvida pode-se apontar a grande necessidade de estudos que incluam grupos não escolarizados, populações rurais ou mesmo trabalhos que abordem outros problemas bucais dos adolescentes, além da cárie.

O levantamento nacional de 1986 (BRASIL, 1988) apresentou para a faixa de 15 - 19 anos um CPO-D de 12,7; mostrou também que apenas $39 \%$ dos jovens de 18 anos não haviam ainda sido submetidos a nenhuma extração dental em decorrência da doença cárie. Quanto à condição periodontal, os dados deste 
levantamento indicaram que somente $28,76 \%$ dos examinados na faixa de $15-19$ anos se encontravam sadios no momento do exame.

Estudo realizado por TUMANG et al (1996), realizado junto à população de Maringá - PR, mostra um CPO-D de 8,82 para a faixa de 15 - 19 anos, o que significa uma redução de 30\% em relação ao levantamento nacional de 1986 . Trouxe ainda um dado importante indicando que, nesta faixa, $18 \%$ dos jovens já usam ou necessitam de algum tipo de prótese dentária (total, parcial ou fixa).

BALDISSEROTO et al (1996) em levantamento realizado junto a escolares da zona norte de Porto Alegre - RS encontraram um índice CPO-D de 2,38 para a idade de 12 anos e de 3,47 para os 15 anos. Neste mesmo grupo, a presença de maloclusão atingiu $46,7 \%$ e $32,8 \%$ dos escolares de 12 e 15 anos respectivamente.

A condição periodontal dos adolescentes passou a ser uma preocupação maior dos pesquisadores a partir da década de $80 \mathrm{em}$ vários paises que demonstraram um maior controle da cárie. PAIVA (1998) faz um extenso levantamento bibliográfico sobre a saúde periodontal de adolescentes e mostra que a prevalência de doenças periodontais é muito grande. Várias publicações estrangeiras mostram que a saúde periodontal é ainda bastante precária tanto em paises industrializados quanto naqueles em desenvolvimento. GARCIA e CUTRESS (1986) encontraram, em estudo realizado nas Filipinas, que na faixa de 15 - 19 anos apenas $13 \%$ dos indivíduos não apresentaram problemas periodontais. NORDBLAD et al (1986) identificaram em seus estudos que apenas 2,04\% dos jovens de 17 anos da cidade de Espoo (Finlândia) possuiam periodonto sadio e, para a cidade de Chiangmai (Tailândia) entre os jovens com idade média de 18,5 anos, nenhum possuía saúde periodontal. Já em 1994, VIGNARAJAH em levantamento nacional realizado em Antígua, revelou que, aos 12 anos, $26 \%$ dos indivíduos examinados apresentavam saúde periodontal, sendo que para a faixa de 15 - 19 anos este percentual caia para apenas $14 \%$. 
No Brasil pode-se tomar como exemplo o estudo realizado por DINI; FOSCHINI e BRANDÃO (1997) em Araraquara-SP no ano de 1995, no qual apenas $10,6 \%$ dos jovens de 14 anos apresentaram CPITN ${ }^{*}$ igual a 0 , isto é, periodonto sadio. Ainda neste mesmo trabalho os autores, ao compararem a presença de cálculo, e portanto a necessidade de raspagem ou curetagem, na faixa de 15-19 anos, afirmam que os dados encontrados nesta pesquisa e aqueles de 1986 são muito similares, o que indica que, no que se refere às condições periodontais desta população, não houve alteração significativa.

FRAZÃO; NARVAI e CASTELLANOS (1998) em estudo realizado em 1996 junto a crianças de 12 anos para avaliar a presença de oclusopatias encontraram que "a proporção de problemas oclusais é cerca de 1,5 vezes maior na dentição permanente do que na decidua. Enquanto na dentição decidua a proporção de população com problemas oclusais é semelhante a proporção com oclusão nomal, na dentição permanente esta relação é 2,5 vezes maior." Estes autores encontraram que aos 12 anos de idade $71,3 \%$ dos jovens apresentam algum tipo de oclusopatia. Para FRAZÃO (1999) os problemas oclusais têm sua determinação atribuida à:

"Interação entre aspectos genéticos e ambientais. Entre estes últimos destacam-se fatores ligados: ao aleitamento matemo; ao uso de produtos de sucção; à manutenção de hábitos deletérios em idades avançadas; á inflamação das vias aéreas superiores e conseqüente abandono da respiração nasal; à cárie dentária; á nutrição e dieta; e finalmente à exodontias em áreas sem acesso à assistência odontológica."

CPITN = Community Periodontal Index of Treatment Needs. Índice adotado pela Organização Mundial de Saúde que avalia a condição periodontal de grupos populacionais. Pode variar de 0 a 4 , sendo 0 sinónimo de periodonto sadio e 4 a pior condição possivel de ser encontrada, equivalente a bolsa periodontal maior ou igual a $6 \mathrm{~mm}$. 
Neste mesmo trabalho FRAZÃO (1999), reportando a um levantamento realizado em escolas públicas e privadas do município de São Paulo (USP 1997), que seguiu a classificação sugerida no Manual de Instruções da OMS para levantamento epidemiológico em saúde bucal (OMS 1991), traz dados alarmantes para a condição oclusal na idade de 12 anos: apenas $28,7 \%$ da população estudada não apresenta nenhuma oclusopatia e $39,8 \%$ apresentam oclusopatias moderadas ou severas.

Outro problema de grande gravidade para a saúde é o câncer bucal. Este é um problema que tem sido amplamente pesquisado e associado a condições ambientais e a hábitos dos indivíduos como, por exemplo a dieta e o tabagismo. A adolescência configura-se numa fase em que hábitos podem ser modificados ou cristalizados (HAGQUIST e STARRIN 1997), o que torna as açōes educativas e preventivas voltadas para esta fase de grande importância para toda a vida do indivíduo. NOFRE et al (1997) trazem dados fundamentais para a análise epidemiológica deste problema:

“Segundo a Organização Mundial de Saúde (OMS), a incidência do câncer bucal em 1980 ocupava os primeiros lugares, representando $6 \%$ de todos os diagnosticados, sendo o sexto tipo de câncer mais comum no mundo. Sabe-se que estes valores variam de acordo com a região geográfica analisada. Em algumas regiões da India, o câncer bucal é responsável por $40 \%$ de todos os tumores malignos, enquanto na maiona dos paises ocidentais este índice varia de 3 a $5 \%$.

No Brasil, durante o periodo de 1976 a 1985, o câncer bucal estava entre as 8 neoplasias mais freqüentes para ambos os sexos, representando $4,2 \%$ do total de casos diagnosticados."

\footnotetext{
- Neste Manual de Instruções a condição oclusal é classificada em três categorias:

[0] normal; [1] leve [2] moderada/severa.
} 
No que concerne às concepções sobre a saúde bucal do adolescente que supostamente deveriam nortear as ações da área, cabe citar o documento que trata das bases programáticas para a saúde do adolescente do Ministério da Saúde (1989) que traz para isso um item especifico, no qual lembra a preconização da Organização Mundial de Saúde de se atingir, no ano 2.000 , um CPO-D máximo aos 12 anos igual a 3,0 e de que aos 18 anos $85 \%$ dos adolescentes estejam com todos os dentes. Este documento traz a afirmação de que:

"Cabe ao Programa de Saúde do Adolescente enfatizar os aspectos preventivos da saúde bucal, assim como participar de forma integrada com os serviços especializados, para a promoção da saúde integral dessa faixa etária."

Não há neste documento maiores detalhamentos sobre o assunto, o que certamente não ajuda muito àqueles que pretendem ou devem atuar nesta área $e$ que buscam uma diretriz básica para suas atividades. Por outro lado isso permite uma maior liberdade de ação, podendo gerar trabalhos bastante criativos e diversificados.

No que se refere às concepções que o próprio adolescente tem sobre sua saúde bucal, sua boca (com seus componentes, inclusive o dente), o papel desta em sua vida e em suas relações com outras pessoas, ou seja, na sua socialização, não foi encontrado nas bases de dados pesquisadas (Medline e Lilacs) nenhum trabalho especifico. No momento em que vários estudos mostram a crescente autonomia dos adolescentes para tomarem decisões sobre suas vidas, é fundamental para a odontologia que se comece a tentar entender também o que eles pensam e como lidam com estes assuntos.

A afirmação acima pode ser exemplificada com um trecho do trabalho de ELIAS (2000) que referindo-se à observação do comportamento das pessoas que chegavam à clínica médica na qual atuava, notou que: 
"Geralmente os que apresentavam problemas odontológicos, principalmente na região anterior da arcada dental, raramente sorriam ou se comunicavam com os outros, eram tímidos, calados, cabisbaixos ou até somidentes, mas para somir tapavam a região da boca com as mãos, mantinham uma postura sénia e retraida, diferente dos demais.

No decorrer do tratamento, após a reabilitação dos dentes, restauração da saúde e da estética bucal, essas mesmas pessoas vivenciavam uma grande transformação de comportamento, tomando-se mais extrovertidas, mais alegres e principalmente somidentes. Podiam voltar a somir apenas como expressão de felicidade e prazer, e não de ansiedade." 


\section{3 - OS SERVIÇOS ODONTOLÓGICOS E OS PROFISSIONAIS}

Os serviços se constituem em um dos determinantes da saúde de uma população. Esta afirmação também é verdadeira para a saúde bucal e para a parcela da população formada pelos adolescentes. Entende-se que os serviços não podem mais ser pensados e avaliados apenas em termos quantitativos, ou seja, em termos de números de procedimentos que são oferecidos periodicamente à população, mesmo que estes procedimentos incluam atividades educativas como as já tradicionais palestras. O tipo ou a qualidade destes serviços é, sem dúvida alguma, um aspecto básico a ser pensado. Quando se fala de qualidade em serviços deve-se considerar que a quantidade também constitui um de seus componentes, isto é, assume-se aqui que, principalmente, para a saúde pública os aspectos quantitativos e qualitativos não podem ser vistos como pólos opostos no processo de atuação dos prestadores de serviços junto à população. Ao se fazer referência à odontologia coletiva é imprescindivel que se tenha em mente o fato de que a quantidade de trabalho realizado deve sempre trazer um significativo impacto sobre as condições de saúde bucal da população alvo. Essa noção coloca a quantidade como mais um dos componentes da qualidade dos serviços. Porém, se são poucos os trabalhos relativos à epidemiologia bucal e quantidade de ações realizadas junto a adolescentes, pode-se afirmar que menor ainda é a preocupação em se registrar os tipos de ações que são desenvolvidas, para não mencionar avaliações da qualidade das ações. 
Os serviços não acontecem por determinação exclusiva de normas ou regulamentos. É evidente que, em qualquer instituição, existe uma "cultura" própria, fruto das experiências acumuladas de todos que ali atuam, das relações entre os indivíduos e os grupos, bem como um histórico institucional que determinam a forma como as ações se desenvolvem. Muito embora esta seja uma verdade inconteste, a forma verticalizada com que alguns gestores e administradores atuam faz parecer que estes desconsideram este fato. Ainda existem gestores que seguem criando normas e modelos a partir de experiências alheias à realidade local, ou mesmo a partir de suas próprias idéias, tentando impô-las sem nenhuma consulta ou participação daqueles que devem executa-las. Ou seja, agem como se desconhecessem que existem sujeitos concretos que executam as ações - os profissionais funcionários - os quais, como individuos que são, trazem em si diferentes concepçōes sobre o mundo que os cerca, reagem de forma diferente aos estimulos, agem de maneira diversa em relação a distintos momentos de suas vidas, enfim, estes sujeitos são elementos fundamentais na determinação do que realmente acontece e na construção da realidade, ao mesmo tempo em que são constantemente influenciados pelo mundo que os cerca.

As ações na área da odontologia têm sido desenvolvidas, em quase todos os serviços de saúde, de forma isolada das demais ações. Toda a sua estrutura administrativa, seus recursos, suas ações educativas, até mesmo sua localização física dentro das unidades tem sido separada. Isso tem levado a situações muitas vezes indesejáveis, criando problemas de toda ordem, desde os mais óbvios na área de planejamento e administração como a aquisição de materiais e processos de licitação, até questões de recursos humanos e relacionamento interpessoal.

Para os usuários dos serviços acaba se passando a impressão de que a boca não tem relação alguma com sua saúde, já que para resolver questões de boca procura-se "os dentistas" e para as questões de saúde geral procura-se a 
"unidade de saúde". Esta separação entre "questões de boca" e "questões de saúde", da forma como os serviços a apresentam, se inicia para os usuários já no processo de agendamento odontológico que é completamente à parte dos demais agendamentos. Para a parcela da população que é incluida nos programas odontológicos, começa pela localização física dos serviços de odontologia, passa pelas atividades educativas, que quase sempre se resumem no ensino de técnicas de higienização bucal, e segue com o exame feito pelos profissionais que, via de regra, se limita aos aspectos físicos da boca ou, menos ainda, do(s) dente(s) em questão. Até mesmo a própria intervenção clínica costuma ser quase sempre pontual, com vistas a resolver unicamente os problemas identificados.

Considera-se, nesta pesquisa, que os profissionais, funcionários da unidade são os sujeitos que mais diretamente determinam o que é realizado dentro dela, mas não são apenas eles que determinam as ações. A princípio todos os funcionários dos diferentes níveis, desde aqueles que atuam no nivel local, na unidade, até o mais hierarquizado no nível decisório, passando pelo nivel tócnico intermediário, podem ter algum tipo de influência no que é desenvolvido na área de saúde do adolescente, especificamente saúde bucal do adolescente. Por esta razão, foi considerado fundamental incluir neste trabalho, além de dentistas, a responsável pela triagem de pacientes, a chefe da unidade, técnicos de planejamento do nivel central e a profissional que tem ligação direta com as ações da saúde do adolescente ou da odontologia no serviço em questão.

Buscou-se investigar a existência de programas voltados para a saúdo do adolescente, como se dá a inserção da saúde bucal nesses programas, ou programas e ações específicas de saúde bucal cuja atuação seja junto a adolescentes. Todos os funcionários ligados a estes programas foram, a princípio, considerados sujeitos desta pesquisa. Deste modo, levando em conta as limitações de um trabalho acadêmico desta natureza, foram selecionados apenas aqueles que, ocupando cargos chave no momento da realização deste trabalho, apresentassem a ligação mais direta possível com o objeto de estudo. 


\section{4 - PROMOÇÃO DA SAÚDE}

A promoção da saúde tem se constituído, nos últimos anos, em um campo bastante rico de pesquisa e ação. Desde 1986, com a realização da Conferência de Ottawa, seus conceitos e estratégias têm se difundido e constituído em norteadores para os que pensam a área de saúde. Note-se que muitos destes conceitos já se faziam presentes em documentos anteriores como a declaração de Alma-Ata, de 1978 (Brasil 2001). No entanto, tem sido as Conferências Internacionais de Promoção da Saúde os fóruns mais importantes da área, até porque têm apontado as bases conceituais, as estratégias a serem adotadas e representam um comprometimento dos participantes. Foram já realizadas outras quatro Conferências a nível mundial sobre o tema - Adelaide, 1988; Sundsvall, 1991; Jacarta, 1997 e México 2000. Foi também realizada a Conferência de Bogotá em 1992, voltada especificamente para a América Latina.

Da Carta resultante da Conferência de Ottawa (Ministério da Saúde 1996) pode-se extrair o conceito que tem sido norteador das ações de promoção da saúde em todo o mundo, embora, nas Conferências posteriores tenham sido agregados alguns novos aspectos :

"Promoção da saúde é o nome dado ao processo de capacitação da comunidade para atuar na melhoria da sua qualidade de vida e saúde, incluindo uma maior participação no controle deste processo." 
Neste documento busca-se resgatar o compromisso individual e coletivo que todos devem ter para se atingir o objetivo comum de "Saúde Para Todos Até o Ano 2.000." Para o cumprimento deste objetivo é apontado que:

"A promoção em saúde exige a ação coordenada de todos os setores envolvidos: os govemos, os setores sanitánios e outros setores sociais e económicos, as organizações filantrópicas, as autoridades locais, a indústria e os meios de comunicação." (OMS, 1986)

Assim, o conjunto de políticas públicas numa ação intersetorial se constituiria num centro de produção social da saúde. Pode-se entender que a implementação de uma política de promoção da saúde teria que combinar "enfoques diversos, se bem que complementares, entre os quais figuram a legislação, as medidas fiscais, o sistema tributário $e$ as mudanças organizacionais." (MINISTÉRIO DA SAÚDE 1996)

Ainda nesta Carta são apontados como pré-requisitos para a saúde: paz, habitação, educação, alimentação, renda, eco-sistema estável, recursos sustentáveis, justiça social e eqüidade. A promoção da saúde abrange, portanto, muito mais que ações restritas ao campo tradicionalmente entendido como especifico da saúde.

Seus campos de ação se constituem na construção de políticas públicas saudáveis, na criação de ambientes favoráveis à saúde, no desenvolvimento de habilidades individuais, no reforço da ação comunitária e na reorientação dos serviços de saúde. Embora entenda-se que estes 5 campos são complementares e interdependentes, cumpre ressaltar o papel dos serviços de saúde. 
LAURELL (1997) ao analisar a politica de saúde no contexto das políticas sociais aborda, entre outros temas, a questão dos serviços de saúde, resgatando sua relevância:

"Ainda que o peso específico dos serviços de saúde no melhoramento das condições coletivas de saúde seja um tema em debate, não se pode supor que é irrelevante. E, além disso, um fato incontrovertido que a sociedade contemporánea tem valorado como um direito importante dispor deles já que se considera, com razão ou não, que pode significar a diferença entre a vida e a morte; entre a restrição da capacidade fisica ou mental e o pleno desempenho destas capacidades; entre a dignidade da pessoa e condições humilhantes."

Particularmente na odontologia, os serviços assumem grande importância em função do contato prolongado que acontece entre o usuário e o profissional. Enquanto no atendimento médico este contato se limita a uma ou duas consultas bastante curtas, na odontologia, dependendo do caso, pode-se estender por várias semanas. Esta diferença torna-se ainda mais marcante quando se incluem nesta análise as atividades educativas, hoje já incorporadas ao cotidiano odontológico. Portanto não seria exagero imaginar que o olhar da saúde bucal pode trazer para si a responsabilidade de repensar a forma de organização dos serviços, tornando-os muito mais aptos a atender as exigências da promoção da saúde. Some-se a isto o dado trazido por PINTO (1995) de que $70 \%$ dos latinoamericanos contam apenas com os serviços públicos onde trabalham apenas $25 \%$ dos dentistas, o que mostra que o olhar da profissão ainda è voltado predominantemente para a clínica privada, dificultando o pensar e inovar no serviço público.

A Declaração de Adelaide de 1988 teve como tema central as politicas públicas saudáveis, afirmando que: 
“O principal propósito de uma política pública saudável é criar um ambiente favorável para que as pessoas possam viver vidas saudáveis. As políticas saudáveis facilitam opções saudáveis de vida para os cidadãos. Criam ambientes sociais e físicos comprometidos com a saúde. Para formular politicas públicas saudáveis, os setores govemamentais de agricultura, comércio, educação, indústria e comunicação devem levar em consideração a saúde como um fator essencial. Estes setores deveniam ser responsabilizados pelas conseqüências de suas decisões políticas sobre a saúde da população. Deveriam, também, dar tanta atenção à saúde quanto aos assuntos econômicos."

Nesta Conferência são apontadas 4 áreas definidas como prioritárias para promoção de políticas públicas saudáveis: apoio à saúde da mulher; alimentação e nutrição; tabaco e álcool e ambientes saudáveis. $O$ desafio posto é o de entender e fazer com que açōes especificas, como as ações educativas da odontologia voltadas para o adolescente, possam contribuir na promoção destas áreas consideradas prioritárias, sempre considerando que prioridade não significa exclusividade, como bem lembra PINTO (1989), e que as ações de todas as áreas assumem importância quando se pensa a saúde da forma que é concebida aqui.

A Declaração de Sundsvall de 1991 traz uma definição de ambiente saudável englobando "aspectos físico e social do nosso entomo. Este termo alcança os espaços nos quais as pessoas vivem: a comunidade, suas casas, seu trabalho e lazer. Também engloba as estruturas que determinam o acesso aos recursos para viver e as oportunidades para ter maior poder de decisão."

Tais aspectos colocam a questão da saúde presente em todos os locais nos quais as pessoas vivem e desenvolvem suas atividades. A importância dos espaços diretamente voltados para os cuidados da saúde, como as unidades básicas de saúde, é resgatada na medida em que estas se inserem na vida 
mesma das comunidades e não se mostram como um anexo necessário, porém totalmente externo às suas vidas cotidianas.

Um dos pontos que tem estado presente nos movimentos brasileiros de luta pela saúde desde a concepção da reforma sanitária da década de 70 e que roi inserido na nossa Constituição de 1988 é a visão da saúde como direito inalienável de todos os seres humanos. Embora este seja um item que vem sendo alvo de muitas discussōes e polêmicas nos campos político, administrativo e ideológico, ele tem se mantido presente no ideário da promoção em saúde, podendo ser identificado na Declaração de Jacarta de 1997 nas seguintes palavras:

"A saúde é um direito humano fundamental e essencial para o desenvolvimento social e económico. (...) A promoção da saúde, mediante investimentos e ações, atua sobre os determinantes da saúde para criar o maior benefício para os povos, para contribuir de maneira significativa para a redução das iniqüidades em questão de saúde, para assegurar os direitos humanos e para a formação do capital social."

Note-se aqui o aparecimento do conceito de "capital social". Segundo KAWACHI et al (1997) capital social: "consiste do engajamento civico e niveis de confiança mútua entre os membros de uma comunidade. Engajamento cívico refere-se ao grau de envolvimento que os cidadãos têm com suas comunidades e, é mais, freqüentemente, medida pelo número de membros participantes em grupos ou associações."

É ainda na Declaração de Jacarta (1997) que se encontram listados os pré-requisitos para a saúde: paz, abrigo, instrução, segurança social, relações sociais, alimento, renda, direito de voz das mulheres, eco-sistema estável, uso sustentável de recursos, justiça social, respeito aos direitos humanos e eqüidade. E aqui a pobreza é vista como, "acima de tudo, a maior ameaça à saúde". 
As leituras atuais mostram claramente a importância da criação de alianças e parcerias para se alcançar a promoção da saúde nesta realidade de globalização. Não é mais possivel se pensar em ações que atinjam apenas o setor saúde, portanto é preciso que as atividades desenvolvidas dêem espaço para que reflexões e ações abranjam muito mais que o simples combate ou prevenção de doenças, por mais que isto ainda seja uma tarefa necessária.

Em junho de 2.000 aconteceu, na cidade do México, a $5^{\text {a }}$ Conferência Global sobre Promoção da Saúde. No documento disponibilizado na internet pela OPAS/OMS (site: //C/OO-NEW-WEB/Portuguese/hpp/mexdec2000.htp) aparece o subtitulo Promoção da Saúde: rumo a uma maior equidade. Declaração Ministerial do México para a Promoção da Saúde. Este subtítulo não consta na publicação do Ministério da Saúde de 2.001 que engloba os documentos das 5 Conferências Internacionais de promoção da saúde, a Declaração de Bogotá, a Declaração de Alma-Ata e Rede de Megapaises. (Brasil 2001). Um aspecto a ser destacado neste evento foi o de que, embora tratando-se do documento mais curto de todas as Conferências, este assumiu um caráter muito mais oficial, já que foi assinado pelos Ministros dos paises participantes. Estes constataram uma "necessidade urgente" de abordar os determinantes sociais, econômicos e ambientais da saúde, fortalecendo os mecanismos de colaboração para a promoção da saúde em todos os setores e niveis da sociedade. Concluem que "a promoção da saúde deve ser um componente fundamental das políticas e programas públicos em todos os paises na busca de equidade e melhor saúde para todos."

Visando resguardar as especificidades de cada pais ou região, em 1992, na cidade de Bogotá, a Organização Pan-Americana de Saúde e o Ministério de Saúde da Colômbia, promoveram uma Conferência para "definir o significado da promoção da saúde na América Latina." 
A Declaração de Bogotá (1992) traça as principais estratégias e compromissos para a promoção da saúde na América Latina. Dentre estes, destaca-se: "fortalecer as capacidades da população para participar nas decisões que afetam sua vida e para optar por estilos de vida saudáveis. "(OPAS, 1992)

Reunindo representantes de 21 paises sulamericanos, portanto países em desenvolvimento, esta Conferência mostra uma grande preocupação em associar saúde e desenvolvimento. Assume que: "A região, desgarrada pela inequidade que se agrava pela prolongada crise econômica e pelos programas de políticas de ajuste macroeconômico, enfrenta a deterionização das condições de vida da maioria da população, junto com um aumento de niscos para a saúde e uma redução de recursos para enfrentá-los."

Ainda neste documento de Bogotá faz-se a afirmação de que cada sociedade "define seu bem-estar como uma opção particular de viver com dignidade." Logo a seguir atribui à promoção da saúde não só o papel de identificar os fatores que favorecem à inequidade e propor ações para combatelos, como também atuar como um agente de mudança, induzindo "transformações radicais nas atitudes e condutas da população e seus dinigentes, onigem destas calamidades."

Embora alguns segmentos da odontologia venham utilizando o termo "promoção da saúde" de uma forma bem mais restrita, que se limita quase que exclusivamente à adoção de medidas preventivas voltadas para a saúde bucal e a atos educativos que, no mais das vezes, têm um caráter meramente informativo, é possivel identificar no seio da categoria indivíduos e grupos que trabalham com uma visão bem mais integrada e ampla da saúde bucal. Existem relatos de experiências onde a odontologia se mostra atuante junto à população, ouvindo-a e procurando trabalhar junto dela na construção de um ideal comum. É preciso, contudo, reconhecer que muito ainda há para se caminhar e talvez seja 
exatamente no ideário da promoção em saúde que estejam os indicativos dos melhores rumos a tomar. 


\section{5 - A EDUCAÇÃo EM SAÚdE}

Neste trabalho parte-se do pressuposto que a educação tem, inevitavelmente, um propósito e um impacto social. Este propósito pode ser traduzido nas palavras de WEARE (1993) o qual, referindo-se aos filósofos da educação, afirma que "a meta central da educação é capacitar as pessoas a serem autônomas. Ser educado é essencialmente ser livre, ter controle da própria vida, ser capaz de pensar racionalmente e logicamente e tomar decisões sem coerção ou medo."

O impacto social das ações educativas não pode ser medido a priori, embora suas bases possam estar implícitas nos propósitos traçados. Este impacto irá diferir, dependendo das condições individuais, do grupo atingido, do ambiente e da realidade sócio-cultural. Contudo é preciso ter sempre presente que toda e qualquer ação educativa conduz necessariamente a um impacto social quando levada a cabo. CORDON-PORTILLO E PAES (2000) chamam a tenção para a estreita ligação entre promoção de saúde educação e empoderamento, termo este derivado do inglês empowerment, que busca traduzir as estratégias que visam dar maior autonomia à comunidade, tornando-a apta a estabelecer suas próprias prioridades e traçar as estratégias mais adequadas para alcança-las, o que viria a aoumentar o impacto social das ações educativas. Pode-se traduzir este impacto inclusive em mudanças nas condições de saúde de uma dada população ou de 
individuos, particularmente quando estas ações educativas referem-se diretamente a educação em saúde.

Com este pensamento, pode-se dizer que educar não é persuadir as pessoas a fazer o que uma outra pensa que ela deva fazer. $O$ ato de educar pode assim ser distinto de outros atos realizados meramente na intenção de encorajar as pessoas a adquirir certas crenças, hábitos e/ou valores. Portanto, distingue-se aqui radicalmente 0 ato educativo dos atos realizados por profissionais isoladamente ou mesmo dentro de programas que tenham como único objetivo informar sobre determinado aspecto ou treinar indivíduos a realizarem determinadas ações de maneira mecânica, isto é, sem "pensar racionalmente" ou sem tomar suas próprias decisões.

CANDEIAS (1997), baseando-se no referencial de GREEN e KREUTER, propõe a seguinte definição de educação em saúde:

“Entende-se por educação em saúde quaisquer combinações de experiências de aprendizagem delineadas com vistas a facilitar ações voluntárias conducentes à saúde. A palavra combinação enfatiza a importância de combinar múltiplos deteminantes do comportamento humano com múltiplas experiências de aprendizagem e de intervenções educativas. A palavra delineada distingue o processo de educação de saúde de quaisquer outros processos que contenham experiências acidentais de aprendizagem, apresentando-o como uma atividade sistematicamente planejada. Facilitar significa predispor, possibilitar e reforçar. Voluntariedade significa sem coerção e com plena aceitação dos objetivos educativos implicitos e explícitos nas ações desenvolvidas e recomendadas. Ação diz respeito a medidas comportamentais adotadas por uma pessoa, grupo ou comunidade para alcançar um efeito intencional sobre a própria saúde." 
Evidentemente, reconhece-se aqui a importância fundamental das políticas de saúde ou, de forma ainda mais ampla, das ações de promoção em saúde na melhoria das condições de vida dos indivíduos e das populações. No entanto, o que se busca neste trabalho, lembrando o recorte proposto, é resgatar o papel das açōes educativas dentro de um contexto específico - o serviço da Secretaria Municipal de Saúde de Goiânia, e voltadas para uma determinada população - os adolescentes que procuram este serviço. Entende-se, assim como TONES (1996), que sem o suporte de medidas políticas, econômicas e sociais de grande impacto a educação sozinha não pode conseguir grandes transformações. Por outro lado seria muito dificil conceber a formulação e implementação de mudanças políticas, econômicas ou sociais sem o devido suporte da educação.

Analisando os referenciais teóricos de Educação em Saúde, ROCHA (1997) afirma que:

"A educação em saúde já tem estabelecido o seu próprio campo de conhecimento cientifico e, como tal, deve ser estudado para que as ações desenvolvidas nesta área não sejam pautadas, exclusivamente, no "bom senso" e "boa vontade" dos profissionais envolvidos.

É fundamental que a categoria odontológica reflita sobre este conhecimento. Só assim ela poderá analisar e identificar qual o tipo de prática educativa em saúde que vem desenvolvendo, para que, a partir dessa reflexão, possa ter um maior número de elementos para orientar essa prática em direção a uma educação mais participativa visando melhores resultados."

Cabem agora reflexões mais profundas a este respeito por parte daqueles que atuam junto à população no sentido de analisar as práticas que vêm sendo desenvolvidas nos programas e instituições. Baseando em estudos e experiências já desenvolvidas, já é possivel pensar em ações educativas que superem as informações e os treinamentos que os programas e os profissionais de saúde, 
particularmente na odontologia, costumam oferecer à população e procurar formas de implementar ações de maior impacto para a saúde. 


\section{6 - A EDUCAÇÃO EM SAÚDE BUCAL}

A educação em saúde bucal desenvolvida no Brasil, com raras exceções, tem se caracterizado por ações isoladas, em sua maioria com finalidades de informação ou de treinamento. A população é quase sempre vista como composta por pessoas absolutamente ignorantes sobre a forma adequada de cuidar de suas bocas. A estas pessoas, se possivel individualmente, os profissionais de saúde bucal precisam informar sobre a boca, os processos que se passam em seu interior, os melhores produtos a serem utilizados, bem como treiná-las dentro das melhores técnicas possiveis sobre como realizar os cuidados necessários. O que tem-se buscado, portanto, são técnicas de difusão de informação e de convencimento para uma população vista como passiva e incapaz de iniciativas próprias (VASCONCELOS 1997).

A odontologia, ao pensar em estratégias educativas, tem, tradicionalmente, se aproximado da psicologia e não da educação. Os trabalhos odontológicos que tratam deste tema, quando avançam além da informação, muitas vezes fazem referência à "motivação de pacientes" como forma de alcançar os objetivos propostos. A primeira vista este fato pode causar certa estranheza, mas ao se pensar na forma biologicista, individualista e fragmentada em que ocorre a formação do dentista e, consequentemente, sua prática, fica evidente que é muito 
mais provável esta aproximação com a ciência psicológica, particularmente com suas correntes comportamentais e behavioristas.

A odontologia ainda não mostrou, enquanto categoria, já que é bom repetir, exceções existem, um movimento que mostrasse uma vertente clara de educação em saúde bucal. Parece que esta categoria vem seguindo com muitos anos de atraso, os passos que a educação em saúde já deixou para trás.

Isto faz com que encontremos em documentos recentes teses e proposições que seriam consideradas absurdas se ligadas a outros campos da saúde. Um exemplo é o documento da Organização Pan-americana da Saúde de 1996 que traz um item relativo à saúde dental (OPAS 1996). É muito interessante observar o que é proposto ali como meta educativa, sendo esta apresentada da seguinte forma:

"Meta educativa: os jovens receberão informação pertinente que thes permitirá estabelecer hábitos para o cuidado dental através de toda a sua vida."

Vale ressaltar que este item inclui 4 sub-ítens com os seguintes temas a serem abordados:

“1) Como começa uma cánie;

2) Como controlar a deterionização da dentadura:

a) mantenha sua boca limpa;

b) reduza a quantidade de doces que comes. Todos os açúcares deterioram os dentes;

3) Visitas ao dentista:

a) visite o dentista duas vezes ao ano;

b) o dentista te revisará os dentes e provavelmente te fará uma limpeza bucal;

4) A gravidez e o cuidado dental: 
a) Não se perde um dente por cada gravidez, nem o bebê vai tirar cálcio de teus dentes para formar os seus;

b) O bebê necessita de cálcio e fósforo para desenvolver seus dentes. Se tu tomas uma maior quantidade de leite terás o cálcio que necessitas;

c) Se sofres de vômito é muito importante lavar-se bem;

d) Consulta teu dentista no começo da gravidez. Informa-lhe que estás grávida;

e) Depois do nascimento do bebé não o ponha na cama com a mamadeira de leite ou suco na boca. $O$ açúcar estará em contato com seus dentes e pode causar-Ihe cáries."

Nos dias atuais, após tantas discussões e avanços em relação à educação, é quase inacreditável que uma agência do porte da OPAS produza e divulgue um documento onde a meta educativa se apresenta limitada à recepção de "informações pertinentes". A observação e análise dos 4 subitens que conformam este tema permitem levantar alguns pontos dignos de uma análise mais detida.

No que se refere ao conteúdo, é estranho que somente a cárie seja abordada para um periodo de vida - juventude - onde tantos outros problemas bucais estão presentes. Também no que conceme ao consumo de açúcares só se trata da quantidade e não da freqüência e forma, trazendo ainda uma afimação que iguala todos os tipos de açúcares quanto à "deteriorização" dos dentes. No sub-item 3 indica-se duas visitas anuais ao dentista, como se todos os indivíduos tivessem as mesmas necessidades e o mesmo grau de risco de cárie, e, pior ainda, considera que todas as bocas são provavelmente sujas já que "o dentista te revisará os dentes e provavelmente te fará uma limpeza bucal." Quanto à gravidez, aparentemente escolhida como um estado especial que merece cuidados específicos, não traz nenhuma informação para a atenção da saúde bucal da adolescente grávida e sim sobre a necessidade de alguns minerais para o bebê e para o controle de açúcar na alimentação futura deste. 
Enfim, pode-se perceber que 0 referido documento não leva em consideração o universo dos adolescentes aos quais se refere, vendo-os apenas em sua dimensão biológica, sem capacidade para pensar sua própria saúde e, portanto, como um caderno em branco que precisa ter suas linhas preenchidas por informações que Ines permitirão "estabelecer hábitos para o cuidado dental através de toda a sua vida."

Em seu trabalho de análise do componente educativo dos programas preventivos desenvolvidos no Brasil de 1980 a 1994, ROCHA (1997), avaliando 103 programas encontrou que $33,9 \%$ destes adotam a palestra como estratégia educativa, seja isoladamente, seja associada a outras estratégias; $17,48 \%$ optaram pelo uso exclusivo da orientação individual; enquanto apenas $7,77 \%$ escolheram a reunião como estratégia de ação. Note-se ser esta a única dentre as estratégias utilizadas que permitiria uma troca de conhecimentos já que todas as demais verticalizam a ação pressupondo que alguém "que sabe" transmite conhecimentos para aqueles que "não sabem".

Outra caracteristica que chama atenção nos programas educativos em saúde bucal é que estes se atêm quase unicamente a aspectos cognitivos do processo, deixando de lado as questōes relativas ao social, ao cultural, ao econômico, ao volitivo e ao emocional das pessoas. A única exceção feita ao emocional é a relativa ao medo, quer seja o conhecido medo do tratamento, quer seja quando o "bicho da cárie" é tratado como um monstro que devora os dentes das pessoas.

Mas, para que todas estas dificuldades possam ser superadas é preciso começar por conhecer melhor os individuos e os grupos populacionais com os quais se lida. Entender da melhor maneira possivel todos os componentes que conformam a rede que vai configurar a realidade da saúde bucal. Esta não é uma tarefa simples. É um trabalho que tem que se desenvolver de modo amplo, abrangente, transdisciplinar. Toma-se necessário, portanto, que a odontologia 
comece a receber e a oferecer contribuições para as mais diversas áreas do conhecimento humano. Só assim será possivel reverter o quadro que está posto. 


\section{4 - OBJETIVOS}

\section{1 - Objetivo Geral}

Desvendar a ótica dos adolescentes sobre sua saúde bucal e suas percepções sobre os serviços odontológicos de uma unidade da Secretaria Municipal de Saúde de Goiânia, relacionando-as com as concepções dos profissionais e identificando quais os aspectos comuns e/ou dispares entre ambos. 


\section{2 - Objetivos Específicos}

4.2.1 - Identificar as características dos adolescentes usuários dos serviços públicos odontológicos em uma unidade de saúde da Secretaria Municipal de Saúde da cidade de Goiânia - GO, 1999 / 2.000;

4.2.2 - Identificar os conceitos e concepções destes adolescentes sobre saúde bucal e serviços odontológicos;

4.2.3 - Identificar e analisar as estratégias educativas e promocionais existentes no local;

4.2.4 - Identificar os conceitos e concepções que embasam o trabalho dos funcionários relativos ao processo educativo em saúde bucal de adolescentes;

4.2.5 - Detectar dificuldades ou resistências dos funcionários em adotarem ações educativas voltadas para o adolescente;

4.2.6 - Fornecer subsídios para possiveis ações neste campo. 


\section{5 - METODOLOGIA}

O presente trabalho apresenta-se como uma pesquisa qualitativa onde se busca entender as questões da saúde bucal dos adolescentes que freqüentam uma unidade de saúde.

Após extensas reflexões e discussões com os profissionais responsáveis pelas açōes junto a adolescentes da SMS, ficou determinado que a unidade de saúde que melhor se prestaria ao desenvolvimento desta pesquisa seria um dos Centros de Assistência Integral à Saúde (CAIS) da Secretaria Municipal de Saúde de Goiânia - GO (SMS). O CAIS escolhido localiza-se no bairro Jardim das Amendoeiras e abriga a sede do Projeto de Promoção da Saúde no Distrito Sanitário Leste - PROLESTE (ver item especifico a seguir). Esta unidade foi escolhida por apresentar várias características desejáveis para o desenvolvimento de uma pesquisa desta natureza, entre elas o fato de se constituir em um Centro de Saúde-Escola, de ser uma unidade de alta resolutividade em saúde geral e em odontologia, com grande procura por parte da população, inclusive jovens, e, principalmente, por existir a intenção de implantação de um programa de assistência integral ao adolescente, o que possibilitará que os frutos deste trabalho tenham um aproveitamento imediato. 
A população alvo desta pesquisa, ou sujeitos*, é constituída por profissionais que ocupam cargos que determinam a natureza das ações a serem desenvolvidas com adolescentes na SMS e na unidade. Estes sujeitos foram selecionados a partir de indicações dos profissionais da SMS que nomearam aqueles que poderiam ser considerados informantes-chave para este trabalho. Foi também levado em consideração o fato destes profissionais estarem trabalhando ou terem bastante experiência em trabalhar em contato direto com adolescentes. Além de funcionários da SMS, julgou-se importante incluir, mesmo não pertencendo aos quadros funcionais da SMS, a diretora da Faculdade de Medicina da Universidade Federal de Goiás (UFG), à qual está ligado o Núcleo de Estudos e Coordenação de Ações da Saúde do Adolescente (NECASA), que é a grande referência nas questões da adolescência no estado de Goiás e que mantém uma forte ligação com a SMS nesta área.

Como não poderia deixar de ser, também foram incluidos os próprios adolescentes que procuram a unidade para atendimento odontológico, no intuito de dar voz a estes sujeitos e, naquilo que fosse possivel, comparar suas percepções com aquelas presentes na literatura, documentos e falas dos profissionais.

Trabalhou-se, nesta investigação, com pessoas concretas, ouvindo o que pensam sobre a adolescência e os adolescentes, a saúde bucal, suas percepções e concepções sobre os serviços, especialmente os serviços odontológicos prestados, o papel da boca e da saúde bucal em suas vidas, suas principais dificuldades e fontes de informação sobre o assunto; o que pensam sobre atividades educativas da área, bem como sobre outros aspectos que foram identificados como relevantes para cada um dos entrevistados.

\footnotetext{
Muitos outros termos poderiam ter sido utilizados para designar os indivíduos aos quais se pretende dar voz nesta pesquisa. Optou-se pela utilização do termo sujeito por entender que este dá conta da forma que se pretende trabalhar. Ressalta-se que este termo não traz nenhuma conotação de sujeição, refere-se, ao contrário, aos indivíduos com liberdade de manifestação e capacidade para construir sua própria realidade.
} 
Assim, foram realizadas entrovistas exploratórias que permitiram definir com mais precisão os aspectos a serem tratados e as pessoas consideradas "chaves" para a compreensão da problemática posta. As entrevistas, que se constituíram no principal elemento de análise, foram do tipo semi-estruturadas, com um roteiro prévio de perguntas a serem formuladas (anexos 1 e 2) tanto para os profissionais quanto para os adolescentes. Foi mantida, porém, a liberdade para abordar alguns assuntos que, interessando ao tema da pesquisa, não cabiam ser desenvolvidos com todos os entrevistados. Portanto, novos elementos de análise foram incluídos na medida em que os entrevistados foram revelando a realidade de seus universos. Estas foram realizadas e gravadas nas dependências da SMS, no CAIS das Amendoeiras e, na Faculdade de Medicina-UFG. Todas foram transcritas em sua integra para facilitar a análise de seu conteúdo.

Trabalhou-se, portanto, com funcionários que estão, em seu cotidiano, atuando junto à população ou desenvolvendo atividades técnicas, por entender-se que estes conhecem bem as características do serviço, suas limitaçōes, dificuldades e possibilidades de ação. $A$ intenção foi identificar os conceitos e as concepções destes sujeitos sobre os adolescentes, o papel dos serviços na construção da saúde, sobre o processo educativo da população e estratégias utilizadas; enfim, como estes trabalhadores concebem a relação dos adolescentes com o serviço de saúde, particularmente saúde bucal, e que perspectivas podem apontar. O contraponto foi dado pelos próprios adolescentes entrevistados que são aqueles que estão dentro do serviço e que possuem a visão do usuário, sujeito e objetivo final das ações.

Além das entrevistas com os sujeitos para conhecer melhor seus universos, os dados necessários para se formar o quadro geral do objeto deste estudo foram coletados através de levantamento ou pesquisa bibliográfica, no intuito de conhecer o que existe na área; análise documental para saber o que 0 serviço tem registrado com referência a ações e programas da área e, ainda, observações pessoais, realizadas de modo a complementar os demais dados. 
Nas entrevistas foram tomados todos os cuidados possiveis no sentido de só fazê-las sob consentimento explícito dos sujeitos, garantindo o sigilo, a não identificação dos adolescentes entrevistados, e o uso exclusivo para os fins desta pesquisa.

Passa-se a seguir a um maior detalhamento sobre o local do estudo e procedimentos metodológicos adotados no trabalho. 


\section{1 - MOMENTO E LOCAL DO ESTUDO}

A pesquisa foi desenvolvida no segundo semestre de 1999 e primeiro semestre de 2.000. Foi desenvolvida junto a profissionais ligados às ações relacionadas a adolescentes na Secretaria Municipal de Saúde de Goiânia-GO (SMS). A unidade de saúde escolhida para a realização das entrevistas com os adolescentes pertence à SMS de Goiânia e é sede do Projeto de Promoção da Saúde do Distrito Sanitário Leste, o PROLESTE. Cabe, por isso, descrever as principais características da cidade, da SMS e da unidade, além de entrar em um maior detalhamento sobre o PROLESTE, o que se faz a seguir. 


\subsection{1 - A CIDADE}

Para uma melhor compreensão do cenário em que esta pesquisa foi desenvolvida, faz-se necessária uma apresentação das principais características da cidade. Como se trata aqui de um estudo desenvolvido junto a um serviço de saúde específico, é interessante conhecer alguns dados geo-políticos, históricos, sociais e culturais da cidade em que este se insere, já que estas caracteristicas peculiares se constituem em alguns dos determinantes deste serviço.

Fundada em 1935 e localizada na região Centro-Oeste do Brasil, Goiânia, a capital do estado de Goiás, é uma cidade que, segundo os dados do Instituto Brasileiro de Geografia e Estatística (IBGE);, em 1991 contava com uma população de 922.222 habitantes em seu município, já no levantamento de 1996 * este número subiu para 1.003.477. Estima-se, no entanto, que este número deva subir em cerca de 200.000 quando se incluem os habitantes daqueles bairros que não se encontram nos limites geo-politicos do município de Goiânia, mas nas cidades do entorno. Como o crescimento urbano de Goiânia já atingiu os limites de seu município, as empresas imobiliárias que exploram a região têm como muito mais lucrativo implantar seus projetos de loteamentos ligados às vias públicas da capital e não às do interior. Essa influência dos negócios imobiliários pode ser

\footnotetext{
- Dados baseados no CENSO DEMOGRÁFICO - 1991 da Fundação Instituto Brasileiro de Geografia e Estatística, Rio de Janeiro, publicado em 1994.

"* Dados do IBGE, disponibilizados na internet.
} 
mais evidenciada pela expansão que ocorre notadamente em direção à zona sul, seguindo a mesma tendência imobiliária da maioria das cidades brasileiras. Estes bairros passam então a ficar ligados estruturalmente à capital e não às sedes dos municipios vizinhos, sendo este mais um fator que favorece a que seus moradores utilizem os serviços públicos de Goiânia, inclusive os serviços de saúde, e não aqueles de suas cidades de origem ou de residência.

Sua população é virtualmente urbana - 99,05\%, somente 0,95\% foram enquadrados como rural pelo IBGE, estando estas pessoas ligadas a chácaras ou sítios de lazer ou constituindo-se em pequenos produtores horti-fruti-granjeiros. No entanto, as origens históricas e as atividades econômicas de Goiânia estão profundamente ligadas ao campo e às atividades agro-pecuárias do estado de Goiás.

Quanto à distribuição etária, 21,92 \% da população estão na faixa de 10 19 anos de idade, faixa de particular interesse a este trabalho. (Quadro 3)

Observa-se que, quanto aos índices de alfabetização, do total de habitantes $89,96 \%$ têm 5 anos ou mais de idade, sendo que destes $88,36 \%$ são considerados alfabetizados pelos critérios do IBGE. Esse índice é significativamente superior ao nacional onde apenas $74,85 \%$ são considerados alfabetizados. Números igualmente expressivos são encontrados quando analisa-se os dados referentes ao grau de instrução formal dos chefes de domicílio. Em Goiânia 11,13\% desses possuem nenhuma ou menos de 1 ano de instrução, o que os coloca bem próximos do analfabetismo. No outro extremo, ou seja, aqueles com 15 anos ou mais de instrução, isto é, aqueles que tiveram tempo suficiente de escolarização até para atingir o nível universitário (embora não necessariamente o tenham feito), o número é bem semelhante - 10,46\%. Esse é um ponto que se mostra significativamente diferente do quadro geral do Brasil onde $24,45 \%$ dos chefes de domicilio apresentam-se com nenhuma ou menos de um ano de instrução e onde apenas $5,70 \%$ conseguiram atingir os 15 anos de instrução ou mais. Tal fato pode 
denotar uma maior facilidade de acesso à escola pela população goianiense do que a brasileira, de modo geral.

QUADRO 3 - População de Goiânia por faixa etária, 1991

\begin{tabular}{|c|c|c|c|}
\hline Faixas Etárias & Número & $\begin{array}{c}\text { Freqüência } \\
\%\end{array}$ & $\begin{array}{l}\text { Freqüência } \\
\text { Acumulada }\end{array}$ \\
\hline $0-4$ & 92.570 & 10,04 & 10,04 \\
\hline $5-9$ & 96.739 & 10,49 & 20,53 \\
\hline $10-14$ & 99.374 & 10,77 & 31,30 \\
\hline $15-19$ & 102.862 & 11,16 & 42,45 \\
\hline $20-24$ & 101.383 & 10,99 & 53,44 \\
\hline $25-29$ & 92.028 & 9,99 & 63,43 \\
\hline $30-34$ & 78.278 & 8,49 & 71,92 \\
\hline $35-39$ & 64.777 & 7,03 & 78,95 \\
\hline $40-44$ & 51.298 & 5,56 & 84,51 \\
\hline $45-49$ & 39.170 & 4,25 & 88,76 \\
\hline $50-54$ & 30.334 & 3,29 & 92,05 \\
\hline $55-59$ & 23.824 & 2,58 & 94,63 \\
\hline $60-64$ & 18.388 & 1,99 & 96,62 \\
\hline $65-69$ & 12.908 & 1,40 & 98,02 \\
\hline $70 \mathrm{e}+$ & 18.299 & 1,98 & 100,00 \\
\hline TOTAL & 922.222 & 100,00 & 100,00 \\
\hline
\end{tabular}

Fonte : IBGE, Censo Demográfico, 1994

Quanto aos domicilios, o IBGE considerou a existência de 233.710 unidades, o que significa uma média de 3,92 habitantes por domicilio, um pouco mais baixa que a brasileira de 4,19 ou mesmo a da própria região Centro-Oeste que é de 4,14 habitantes por domicílio, estando bem próxima de estados como São Paulo $(3,89)$ ou do campeão brasileiro nesta área o Rio Grande do Sul $(3,64)$, indicando uma relação bastante satisfatória para os padrões brasileiros. 
Destes domicilios, $78,64 \%$ contam com água proveniente da rede geral de abastecimento a qual é tratada e fluoretada desde 1985. Quanto à fluoretação em análise realizada por CURY (1996) do Laboratório de Bioquimica Oral da Faculdade de Odontologia de Piracicaba da UNICAMP com amostras colhidas em 13 bairros em abril de 1996, foram encontrados resultados que variaram de 0,45 ppm a 0,87 ppm de flúor em uma cidade onde o indice considerado ideal é de 0,7 ppm (quadro 4). Não há heterocontrole do teor de flúor. Nos demais domicílios a água utilizada provem de poço (cisterna) ou dos córregos e rios que cruzam o município. Quanto à instalação sanitária, $74,57 \%$ dos domicílios são ligados à rede geral de esgotos. Esta, no entanto, não sofre ainda nenhum tipo de tratamento sendo os dejetos apenas conduzidos aos cursos de água naturais.

QUADRO 4 - Análise do teor de flúor das águas de abastecimento de Goiânia, abril de 1996.

\begin{tabular}{|l|c|}
\hline \multicolumn{1}{|c|}{ AMOSTRA } & PpmF \\
\hline 1 - S. Aeroporto & 0,62 \\
\hline 2 - S. Marista & 0,75 \\
\hline 3 - Campinas & 0,55 \\
\hline 4 - V. Lucy & 0,51 \\
\hline 5 - Jardim Goiá & 0,69 \\
\hline 6 - V. Santa Helena & 0,51 \\
\hline 7 - Jardim Brasil & 0,68 \\
\hline 8 - S. Pedro Ludovico & 0,69 \\
\hline 9 - Jardim Novo Mundo & 0,59 \\
\hline 10-V. Finsocial & 0,45 \\
\hline 11-S. Bueno & 0,65 \\
\hline 12-S. Bela Vista & 0,87 \\
\hline 13-S. Rodoviário & 0,51 \\
\hline
\end{tabular}

Fonte : Jornal da ABO - GOIÁS, nº 34, mar/abr. 1996. 
A análise do destino do lixo mostra que $93,31 \%$ dos domicílios têm coleta regular e este é levado aos aterros sanitários pelo serviço público, o que faz com que a cidade exiba uma situação bastante favorável neste aspecto.

No que diz respeito à distribuição de riquezas, o índice de GINI de Goiânia é de 0,6172 , mostrando-se um pouco melhor que o do estado de Goiás $(0,6197)$, porém pior que a média brasileira de 0,6366 e bem distante do melhor estado do Brasil - Santa Catarina, que tem o índice igual a 0,5650.

- Índice de GINI : "É uma medida de grau de concentração de uma distribuição, cujo valor varia de 0 (zero) (a perfeita igualdade) até 1 (um) (a desigualdade máxima)." (IBGE, Censo Demográfico 1991, p.13) 


\subsection{2 - A SECRETARIA MUNICIPAL DE SAÚDE}

Quanto à sua estrutura física, a Secretaria Municipal de Saúde de Goiânia conta com 53 unidades de atendimento à saúde, sendo 30 unidades básicas de saúde, 10 módulos odontológicos escolares simplificados e transportáveis, 5 centros de referência, 6 Centros de Atendimento Integral à Saúde (CAIS) e 2 traillers que prestam atendimento junto às creches da prefeitura de Goiânia.

São os seguintes os programas e atividades regularmente desenvolvidos pela Secretaria Municipal de Saúde de Goiânia:

- Programa de assistência integral à saúde da mulher;

- Programa de saúde da família;

- Programa de saúde mental;

- Programa de controle de doenças crônico degenerativas

- Programa de saúde do escolar;

- Atendimento médico nas áreas de: clínica médica, pediatria, ginecologia e obstetrícia, saúde mental e urologia ( DST/AIDS);

- Fornecimento de medicamentos básicos;

- Fiscalização e controle de saneamento básico;

\footnotetext{
- Informações fornecidas pela SMS em dezembro de 2000. Sabe-se, contudo, que todos estes programas e atividades tendem a sofrer grandes transformações a partir do primeiro semestre de 2001 em função das alterações político-administrativas decorrentes da posse do novo prefeito e auxiliares.
} 
- Fiscalização do comércio de alimentos;

- Projeto Circulando com a Saúde (palestras informativas em escolas públicas);

- Projeto de desinfecção de poços rasos (cisternas);

- Programa de vigilância epidemiológica;

- Exames laboratoriais de análises clínicas e citológicas;

- Programa de controle de zoonoses;

- Multivacinação de rotina;

- Programa de capacitação e reciclagem de recursos humanos;

- Atendimento de saúde bucal:

- atendimento odontológico nos centros de saúde;

- atendimento de endodontia (06 a 16 anos);

- educação em saúde bucal (junto às escolas públicas municipais);

- atendimento com traillers em creches e escolas ;

- programa de assistência odontológica ao escolar (módulos odontológicos escolares);

- estágio supervisionado dos acadêmicos de odontologia da Faculdade de Odontologia da Universidade Federal de Goiás. (FO/UFG).

Sobre os cirurgiões dentistas da Secretaria Municipal de Saúde de Goiânia MARCELO (1997) constatou que apenas $38,34 \%$ são do sexo masculino enquanto $61,66 \%$ são do sexo feminino, acompanhando e retratando uma forte tendência de feminilização da profissão. Fato este que, segundo CORDON (1991), "pode eventualmente criar tendências significativamente diferentes no futuro da prática da odontologia." 


\section{1 .3 - O DISTRITO SANITÁRIO LESTE, O CAIS DAS AMENDOEIRAS E O PROLESTE}

Passa-se à apresentação de alguns dados referentes ao Distrito Sanitário (DS-09) e à Unidade de Saúde (CAIS das Amendoeiras) escolhidos para o desenvolvimento deste trabalho. Da mesma forma, cabe também apresentar as principais características* do Projeto de Promoção da Saúde do Distrito Sanitário Leste - PROLESTE, uma vez que é este o projeto que abriga a unidade e que justifica sua escolha para a realização desta pesquisa.

O PROLESTE surgiu como uma proposta de desenvolvimento de um plano de ação com vistas à promoção da saúde do Distrito Sanitário Leste (DS-Leste). A idéia se desenvolveu a partir de um convênio firmado entre a Universidade Federal de Goiás (UFG) e a Secretaria Municipal de Saúde de Goiânia (SMS). Este se oficializou a partir de 1998, permitindo à UFG participar da gerência, bem como utilizar um Centro de Assistência Integral à Saúde - CAIS das Amendoeiras - (fotos 1 e 2) como local de ensino para os diversos cursos da área de saúde, transformando-o em um Centro de Saúde - Escola.

Este Projeto se subdivide em 4 subprojetos, a saber:

\footnotetext{
- Todos os dados referentes ao DS Leste são baseados no Relatório Técnico de 1999, apresentado pelo Grupo Gestor do PROLESTE (UFG/SMS 1999).
} 
1) Subprojeto Escola Promotora da Saúde - que se constitui de ações desenvolvidas nas escolas da rede municipal de ensino e conveniadas da região;

2) Subprojeto Creche Promotora da Saúde - que, como o próprio nome indica, é desenvolvido em creches;

3) Subprojeto Contro de Saúdo-Escola - tendo suas ações centradas no CAIS das Amendoeiras, conta com a participação de diferentes unidades de ensino da Universidade Federal de Goiás;

4) Subprojeto Pólo de Capacitação - que visa criar oportunidades para os funcionários da SMS atualizarem seus conhecimentos em um processo de educação continuada, capacitar membros da comunidade no desenvolvimento de ações voltadas para a Promoção da saúde e permitir a estudantes e professores da universidade uma maior integração com a comunidade, aprendendo com esta no desenvolvimento das atividades, bem como propiciar um campo de pesquisas e estágios práticos.

O presente trabalho foi inserido nos subprojetos Centro de Saúde-Escola e Pólo de Capacitação. Tem sido relatada em várias ocasiões durante as reuniões do PROLESTE a grande necessidade de qualificação dos recursos humanos, o que parece ser uma necessidade percebida em todas as unidades de saúde da SMS, segundo relato dos próprios entrevistados. Esta necessidade é sentida tanto no que diz respeito à formação acadêmica dos estudantes que lá desenvolvem seus estágios e demonstram um grande despreparo para lidar com a comunidade, quanto por parte dos funcionários que não têm tido oportunidade de participar de um processo planejado de educação continuada com formação em serviço. Há a perspectiva de implantação do Programa de Atenção Integral ao Adolescente no CAIS, o qual se constituiria, não apenas em uma atividade de atenção às demandas da região, mas também se constituiria 


\section{Goiânia, Macro-regiões da SMS, 2001}

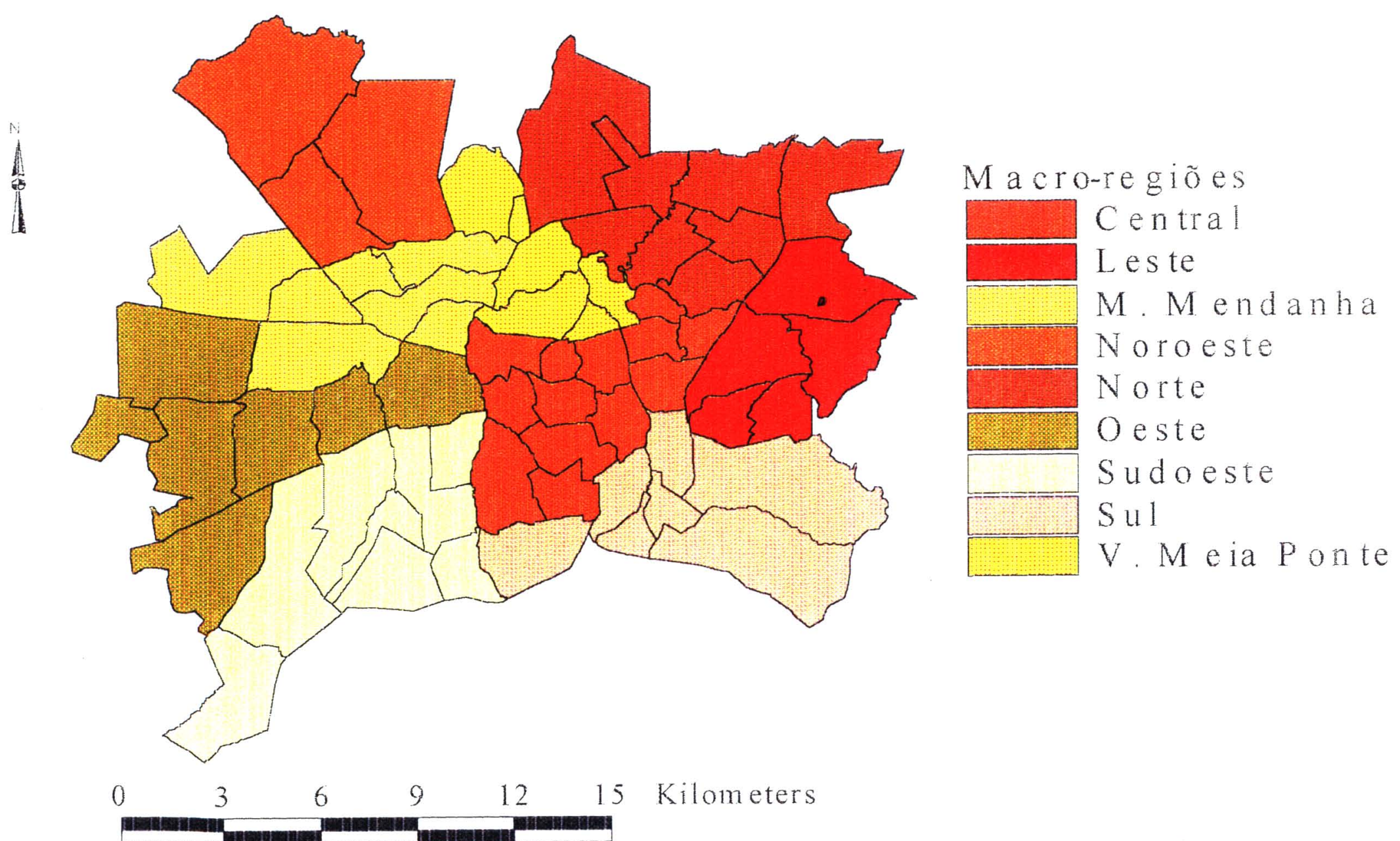



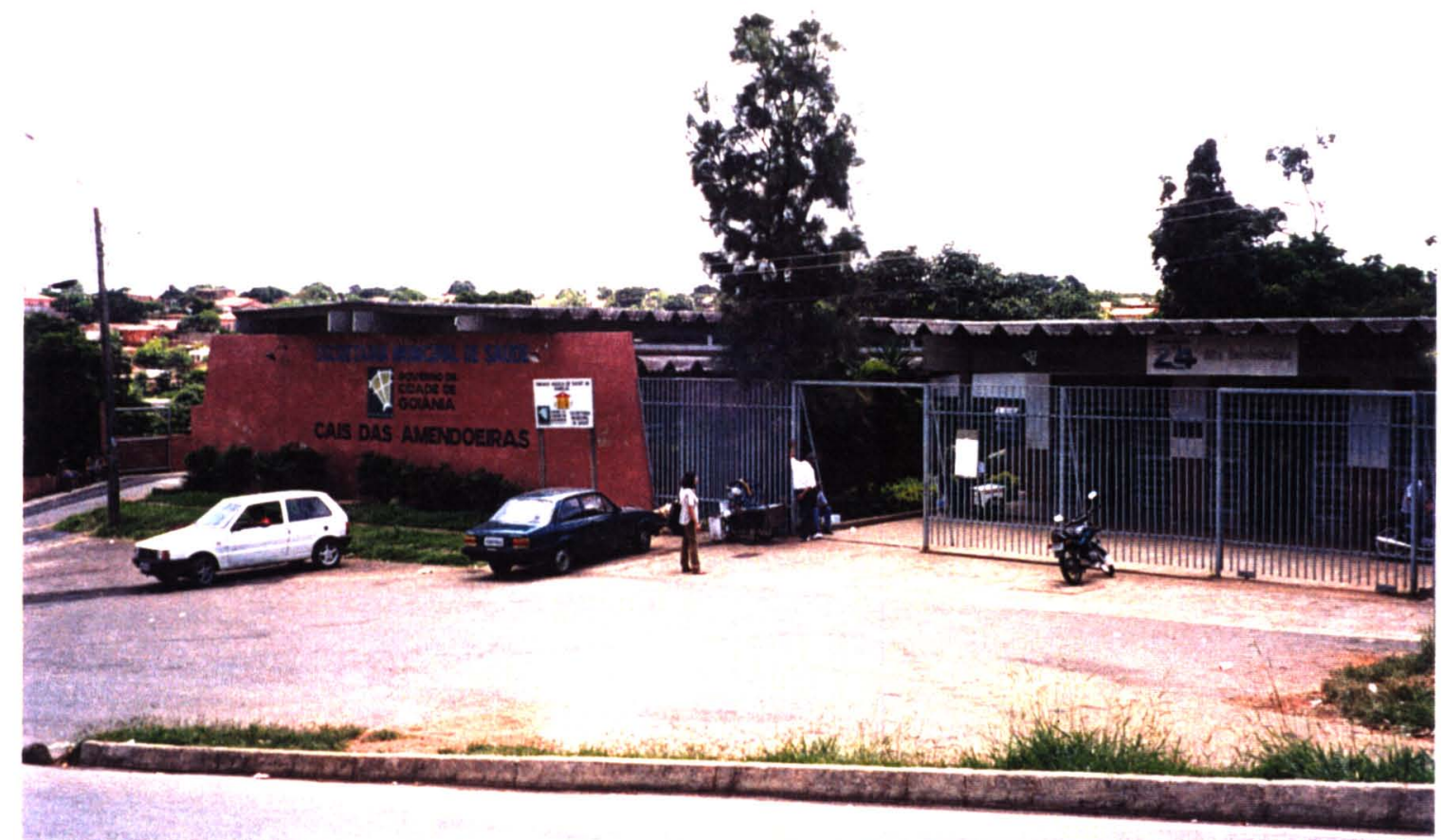

Foto 1 - Entrada do Cais das Amendoeiras

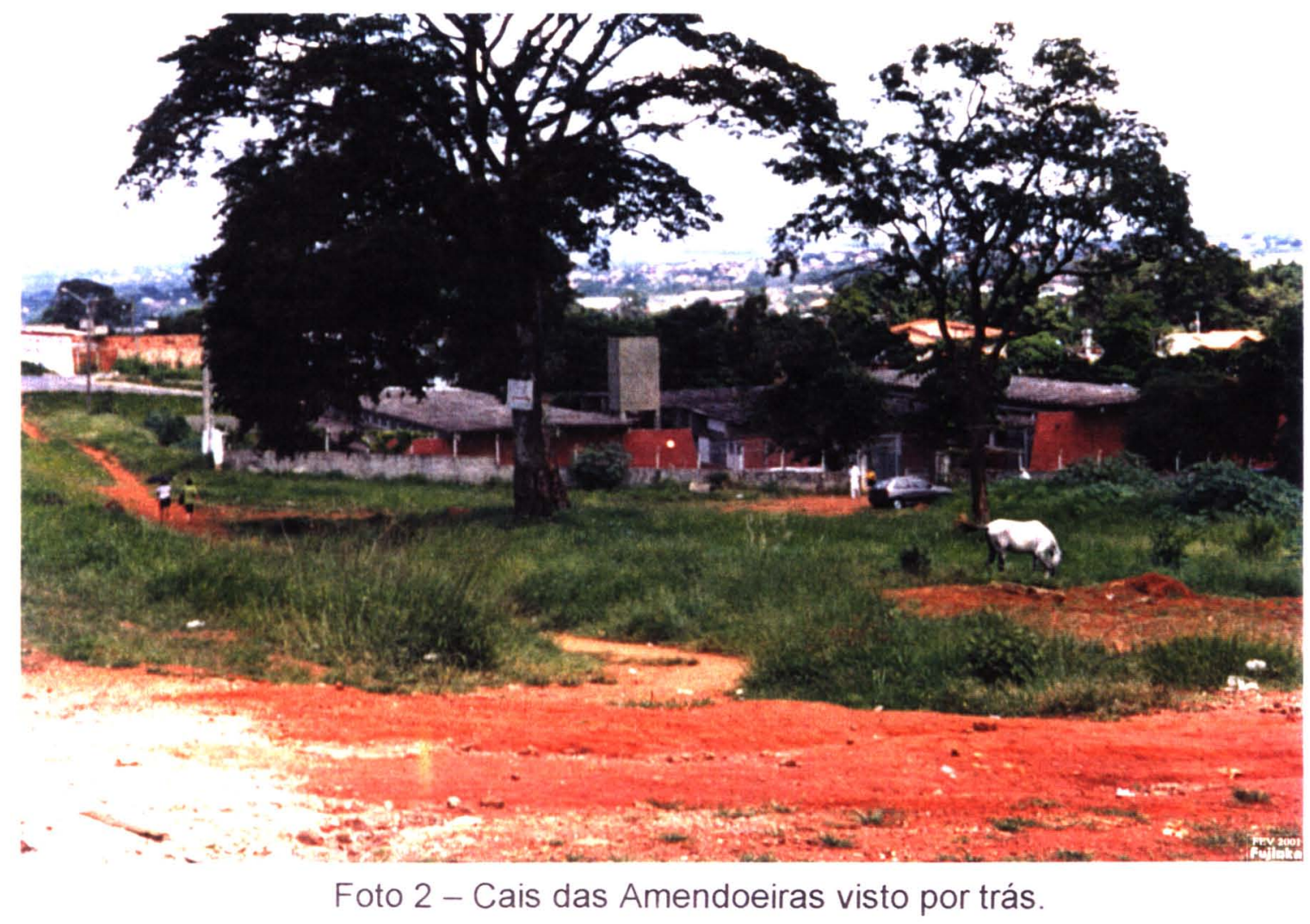


ern um modelo para a implantação de programas semelhantes em outras unidades da SMS.

O Centro de Saúde-Escola é uma proposta de trabalho que congrega interesses acadêmicos e de serviços, se consubstanciando em um delineamento de atividades que visam otimizar/implementar as atividades dos serviços de saúde da área de abrangência, ampliando suas ações para outros espaços sociais desta mesma área.

Esta noção de Centro de Saúde - Escola foi repensada e ampliada, não se restringindo apenas à prestação de serviços de saúde ou à sua reorientação. $O$ que se busca atualmente com o PROLESTE é o envolvimento de toda a população da região em ações de promoção da saúde nos moldes dos pressupostos da Carta de Ottawa, numa proposta de Distrito Sanitário Saudável.

A implementação do PROLESTE envolve várias parcerias de instituições e entidades que existem na região. Já se fazem participantes, além da UFG e da SMS, o Programa Saúde da Familia - Área Leste, o Conselho Local de Saúde do Parque Amendoeiras, o Centro Comunitário Jardim das Aroeiras, a Associação de Bairros da Região Leste -UNILESTE, o Conselho de Segurança Pública Comunitária da Região Leste, a Cooperativa de Reciclagem -COOPREC (foto 3) com a Usina de Reciclagem de Lixo, o Centro de Formação Profissional, a Escola de Circo (foto 4), o Horto/Horta medicinal, o Programa de Educação Ambiental, a Secretaria Municipal de Cultura, Esportes e Lazer e a Secretaria Municipal de Educação. 


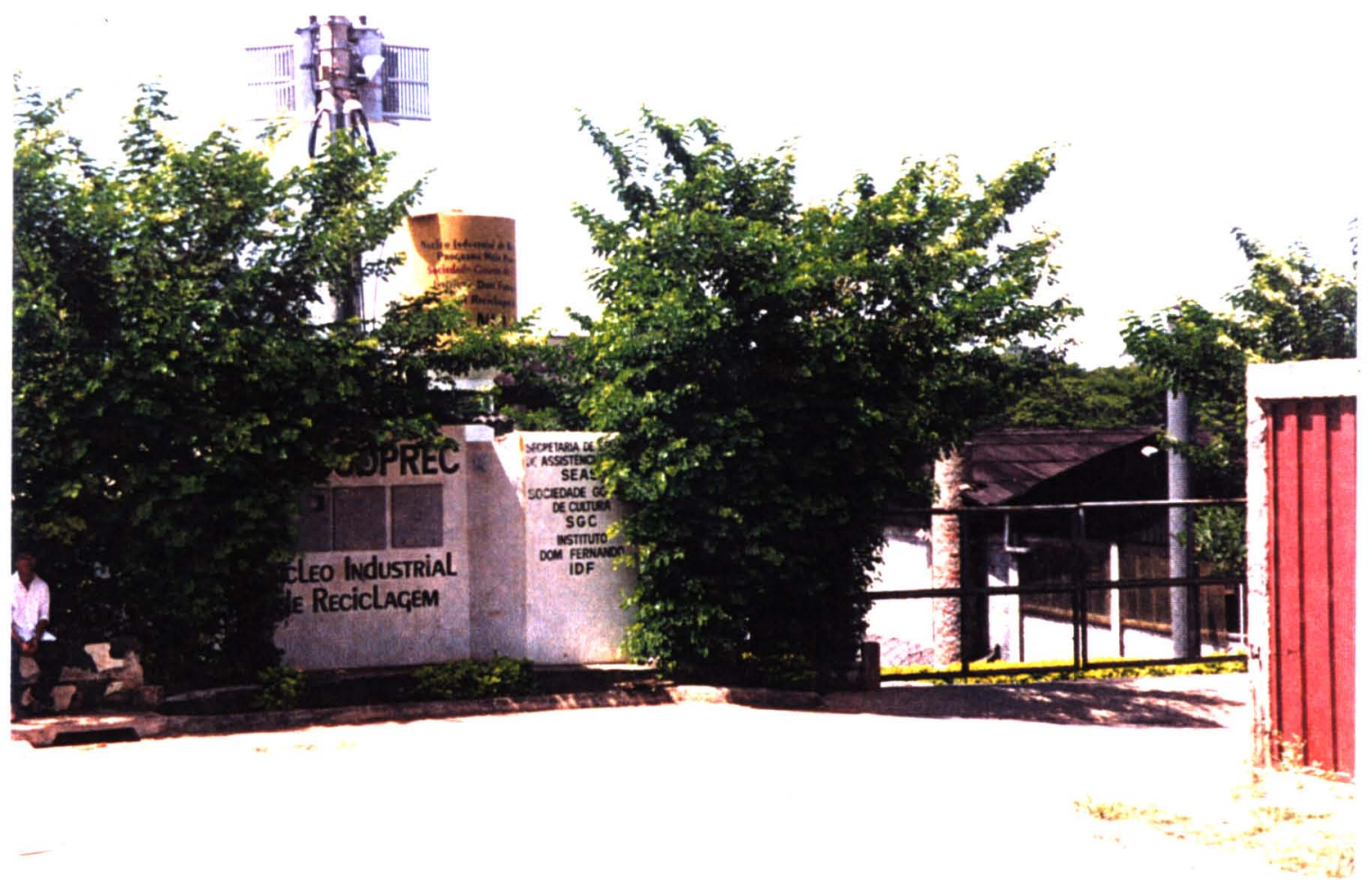

Foto 3 - Entrada do Núcleo de Reciclagem.

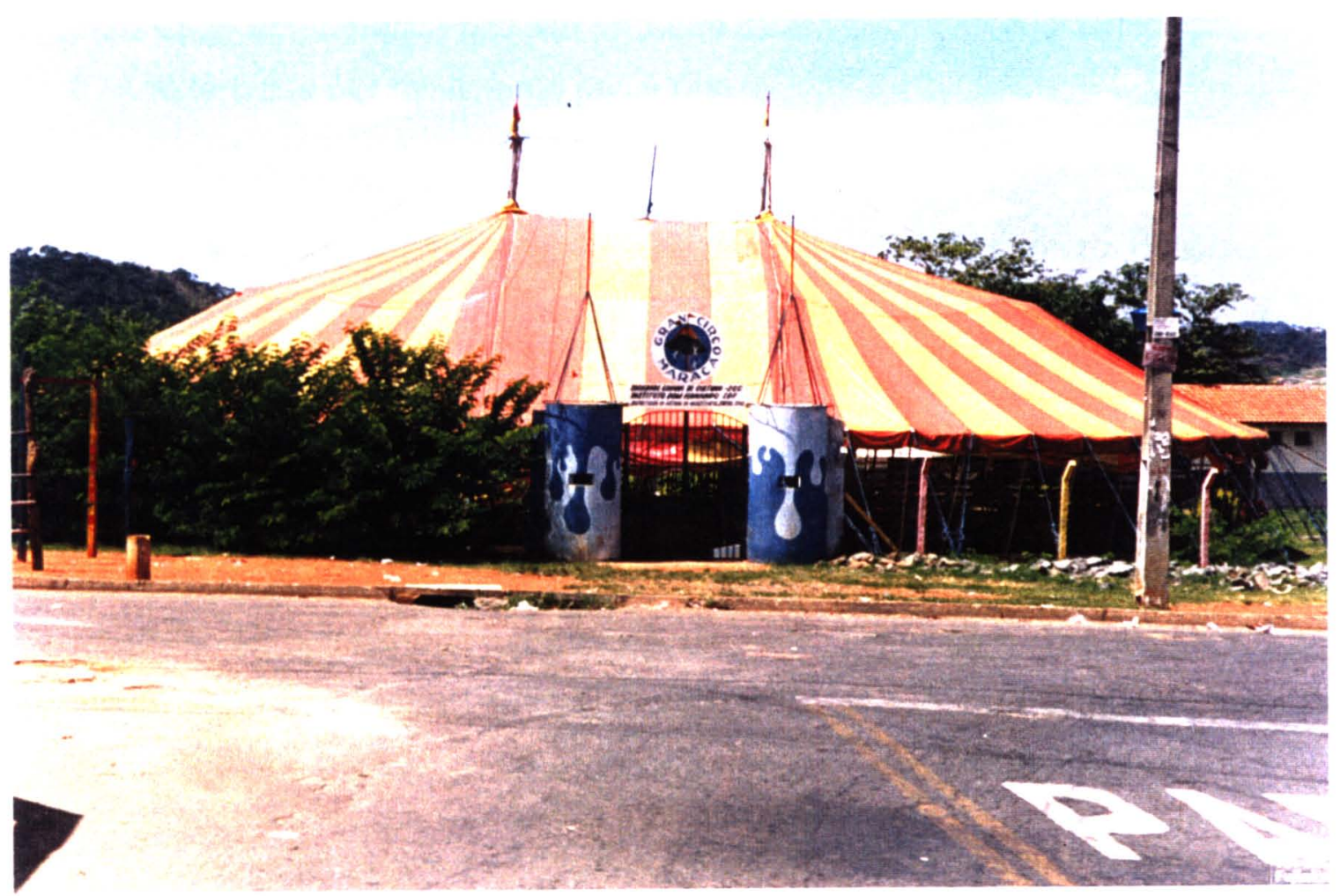

Foto 4 - Escola de Circo que atende crianças e adolescentes da região. 
Para planejar, coordenar e implementar as ações do PROLESTE foi criado um Grupo Gestor, aberto à participação de representantes de todos os parceiros envolvidos. Este se reúne semanalmente, no CAIS das Amendoeiras, sob a coordenação de uma docente da UFG e tem como característica fundamental ter suas reuniões abertas à participação da população de modo geral.

O Distrito Sanitário Leste (DS-09) compõe-se de 45 bairros e 7 unidades de saúde que se enquadram nos niveis de pequena e média complexidade, e uma destas é o CAIS Parque das Amendoeiras, onde está situada a sede do PROLESTE.

A população residente que compreende a área de abrangência do DS-09, segundo estimativa do IBGE e dados do Programa Saúde da Família - PSF, em 1.999, é de 119.570 habitantes, sendo do sexo masculino, 57.394 , e do sexo feminino, 62.176 habitantes (quadro 5). Este número representa $11,7 \%$ da população de Goiânia. A taxa geométrica de crescimento é de $2,3 \%$ anual e a densidade demográfica gira em tomo de $1.097 \mathrm{hab} / \mathrm{Km}^{2}$. A dinâmica populacional é caracterizada por movimento migratório.

Esta população conta, em seu bojo, com um número considerável de imigrantes vindos principalmente de outros estados, principalmente da Bahia, Maranhão e Minas Gerais. Além daqueles vindos do interior de Goiás e de outros bairros de Goiânia. O número de domicílios particulares ocupados é de 29.893 .

O Distrito Sanitário Leste está situado na Região Leste, da cidade de Goiânia, capital do Estado de Goiás. Faz parte da bacia hidrográfica do Rio Meia Ponte e do aglomerado urbano de Goiânia. Tem como limites geográficos ao Norte, o córrego Matão; ao Sul, o córrego Gameleira; ao Leste, a avenida Pedro Rasmussem e BR 153 e a Oeste, o córrego Lageado ou Capoierão. 
QUADRO 5 - Demonstrativo da população por faixa etária e sexo, Distrito Sanitário Leste, Goiânia-GO, 2000.

\begin{tabular}{|l|c|c|c|c|}
\hline \multirow{2}{*}{ Faixa etária } & \multicolumn{2}{|c|}{ População por Sexo } & \multicolumn{2}{c|}{ Total } \\
\cline { 2 - 5 } & Homens & Mulheres & N & $\%$ \\
\hline$<01$ ano & 1.607 & 1.741 & 3.348 & 2.8 \\
1 a 4 anos & 6.141 & 6.653 & 12.794 & 10.7 \\
5 a 9 anos & 7.404 & 8.021 & 15.425 & 12.9 \\
10 a 14 anos & 7.232 & 7.834 & 15.066 & 12.6 \\
15 a 19 anos & 6.887 & 7.461 & 14.348 & 12.0 \\
20 a 49 anos & 22.212 & 24.062 & 46.274 & 38.7 \\
50 anos e + & 5.911 & 6.404 & 12.315 & 10.3 \\
\hline \multicolumn{1}{|c|}{ Total } & $\mathbf{6 7 . 3 9 4}$ & $\mathbf{6 2 . 1 7 6}$ & $\mathbf{1 1 9 . 6 7 0}$ & $\mathbf{1 0 0 , 0}$ \\
\hline
\end{tabular}

Fonte: Relatório Técnico do PROLESTE, 1999 (UFG/SMS 1999)

Sua área é de $109 \mathrm{~km}^{2}$ e seu clima pode ser caracterizado como quente e úmido, oscilando sua temperatura, em média das máximas $-30^{\circ} \mathrm{C}$ e das minimas $-16^{\circ} \mathrm{C}$ a média compensada de $21^{\circ} \mathrm{C}$. A sede do DS-09 acha-se a 764 metros acima do nivel do mar e, o ponto mais elevado existente é conhecido como Morro do Macaco.

A rede hidrográfica da região do DS-09 é formada por 10 córregos: Córrego Palmito; Córrego Buriti; Córrego Pilão; Córrego Ladeira; Córrego Abel; Córrego Razão; Córrego Água Branca; Córrego da Mina; Córrego Gameleira; Córrego Lageada e Rio Meia Ponte. Nota-se que, a exemplo de outros conglomerados urbanos, a faixa de terra que beira estes cursos d'água vem 
gradualmente tendo sua vegetação substituida por habitações precárias, o que representa sempre grande ameaça à saúde de seus moradores, particularmente no periodo de chuvas.

Quanto ao padrão de moradia, observa-se que $87,6 \%$ das residências são providas de energia elétrica, $92 \%$ são servidas de água tratada, $11,5 \%$ dispõem de esgoto e $90 \%$ recebem a coleta de lixo em dias alternados. Ressaltando-se que em três bairros da região há o trabalho de coleta seletiva de lixo, feito pela COPREC, a Cooperativa de Reciclagem, que é assessorada pela Universidade Católica de Goiás e é formada por 50 familias da própria região. Esta cooperativa, além de se constituir em fonte de renda, faz um trabalho educativo com os moradores enfatizando as questões de meio ambiente e saúde.

A Cooperativa de Reciclagem do Lixo tria, recicla e industrializa 10 (dez) toneladas de lixo/dia, uma média de 300 (trezentas) toneladas lixo/mês. O lixo coletado é proveniente dos Bairros: Jardim das Aroeiras I e II, Dom Fernando I, II e III e Jardim Conquista. Os residuos sólidos urbanos são colhidos por caminhão e os cooperados fazem todas as atividades relativas à fabricação de telhas, fibras asfálticas, grânulos de plástico e sucata de metal ferroso e não ferroso, húmus e outros.

Os vários bairros do DS-09 têm como meios de acesso principalmente os ônibus urbanos e, nos últimos dois anos tem crescido a oferta dos chamados meios "alternativos", que são vans ou mini-ônibus que fazem diversos trajetos pela região. 
Algumas estradas cortam a região. São elas as rodovias BR-4.571 e as rodovias GO 403, GO 010 e GO 020, existe ainda a ferrovia da Rede Ferroviária Federal (R.F.F.S.A), que corta transversalmente a região. Além dessas, existem estradas vicinais que acessam chácaras e algumas fazendas vizinhas. Este grande número de estradas e sua péssima sinalização e manutenção deficiente, tem sido a causa de muitos acidentes que resultam em um maior número de atendimentos de urgência nas unidades de saúde da região.

Existem 20 (vinte) escolas de ensino básico ou fundamental, incluindo as de maternal e pré-alfabetização e as que abrangem todo o ensino fundamental (antigo $1^{\circ} \mathrm{Grau}$ ). Existem ainda 4 (quatro) escolas de ensino médio (antigo $2^{\circ}$ grau). O DS-09 conta ainda com uma infra-estrutura de 14 creches, (6 filantrópicas, 7 estaduais e 1 municipal), atendendo a 1055 crianças de 0 a 16 anos. Conta também com a Escola de Circo que trabalha com crianças e adolescentes da região e constitui-se também em uma opção de lazer não só para a região, mas faz apresentaçōes em vários locais da cidade de Goiânia.

São registradas na área de jurisdição do DS-09, 16 indústrias de grande, médio e pequeno porte, sendo a maior uma empresa do setor de laticínios, a Itambé, com quadro de pessoal de 450 funcionários das diversas categorias profissionais. Oficialmente, existem, em toda área do DS-09, 1076 estabelecimentos comerciais no ramo de secos e molhados.

A população é servida de água tratada, fornecida pela Companhia de Saneamento do Estado de Goiás (SANEAGO). A rede é composta por uma adutora, localizada no alto do Setor Universitário. Segundo técnicos responsáveis, o local atende a 27.988 residências (92\%). As residências 
restantes (8\%) são abastecidas por poços de lençol freático, não sendo exercido nenhum controle de qualidade da água e nem desenvolvidos programas educativos ou de distribuição de cloro. Nesta área, a água de poço e os dejetos são depositados em fossa negra. Ainda segundo informidções colhidas junto à prefeitura, a área conta com rede de coleta de esgoto pluvial e domiciliar em $11,5 \%$ sendo que $88,5 \%$ restante fazem uso da fossa negra e/ou fossa séptica e/ou depositam a céu aberto, e comumente em sua maioria, lançam "in natura" ao Rio Meia Ponte e Córrego Palmito.

A iluminação Pública atinge apenas $24 \%$ das ruas e avenidas, o que é motivo de grande reclamação por parte dos moradores, tendo em vista os altos indices de criminalidade da região.

Segundo dados da Secretaria Municipal de Finanças, existem 133 instituições religiosas distribuídas entre templos católicos, protestantes, espíritas e outras religiões.

A população da área de jurisdição do Distrito Sanitário Leste recebe assistência médico-sanitária através das seguintes unidades:

- CAIS Parque das Amendoeiras;

- CAIS Jardim Novo Mundo;

- Centro de Saúde Vila Morais;

- Centro de Saúde Água Branca;

- Posto de Saúde Conjunto Riviera;

- Centro de Saúde Conjunto Aruanã;

- 01 Núcleo de Apoio Psico-Social;

- 01 Hospital de Dermatologia Sanitária - Colônia Santa Marta; 
- Hospitais, Clínicas e Serviços Complementares de Apoio a Diagnóstico da Rede Pública, credenciados e conveniados pelo SUS, não situados na região;

- Programa Saúde da Família - Região Leste.

O CAIS das Amendoeiras funciona 24 horas por dia, todos os dias do ano. Nesta unidade são prestados serviços ambulatoriais nas áreas médica, de enfermagem, nutrição, psicologia e odontológica. Funcionam também programas regulares de atenção a diabéticos, hipertensos, obesos, gestantes, desnutridos e idosos, bem como o programa de vacinação. Além disso, existem os serviços de urgência nas áreas médica e odontológica. É também no CAIS das Amendoeiras que se encontra a sede do Programa de Saúde da Familia da região.

Para o desenvolvimento das ações da odontologia existe um ambulatório estruturado em forma de hexágono (roseta odontológica) com 6 cadeiras e um lavatório com tomeiras e espelho para a realização da escovação supervisionada. Existe ainda um consultório convencional em uma sala contígua onde são atendidos os casos de urgência. As atividades educativas são realizadas no auditório do CAIS e na própria sala de atendimento. O próprio corredor da unidade é utilizado como sala de espera. 


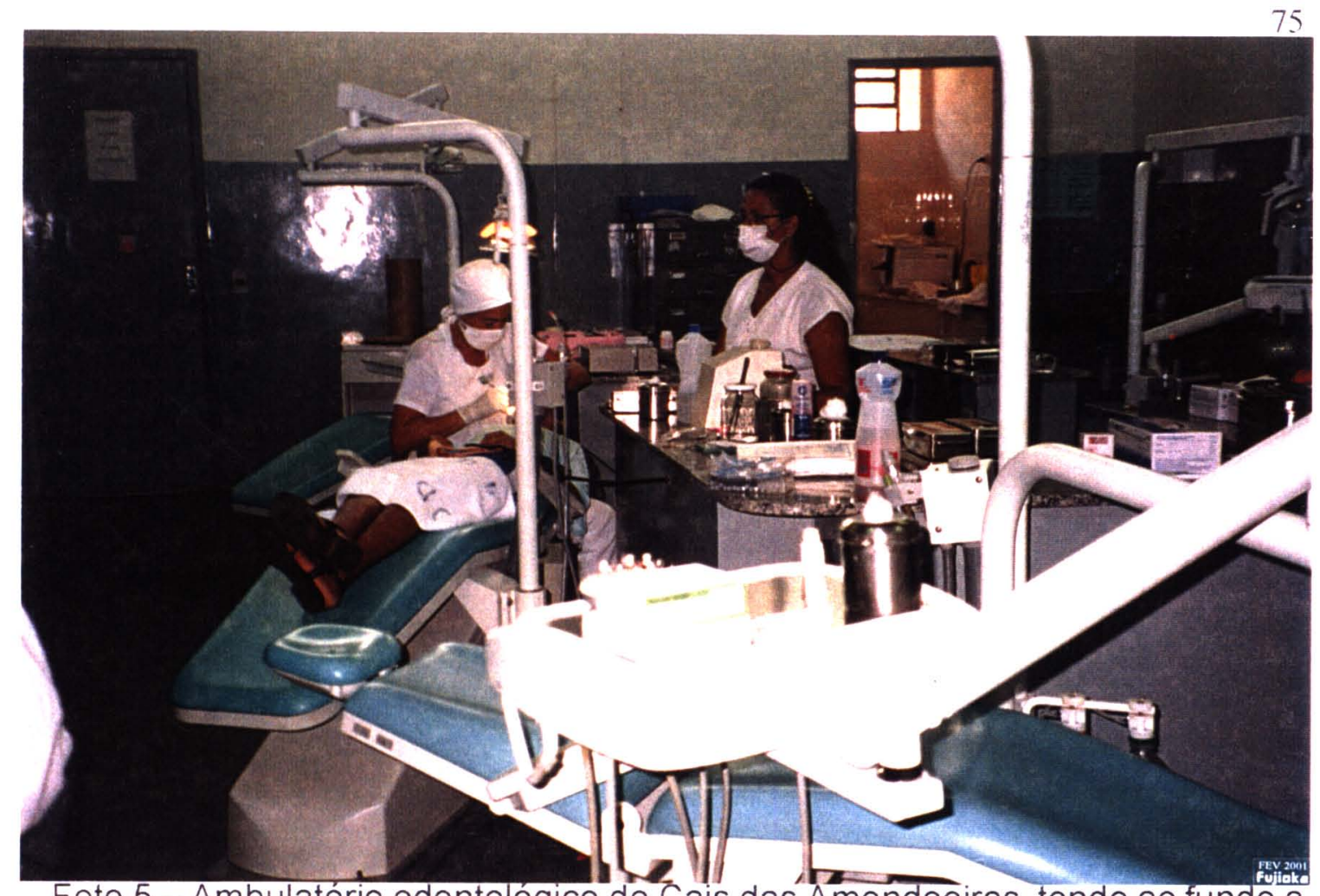

Foto 5 - Ambulatório odontológico do Cais das Amendoeiras, tendo ao fundo a entrada para a sala de expurgo.

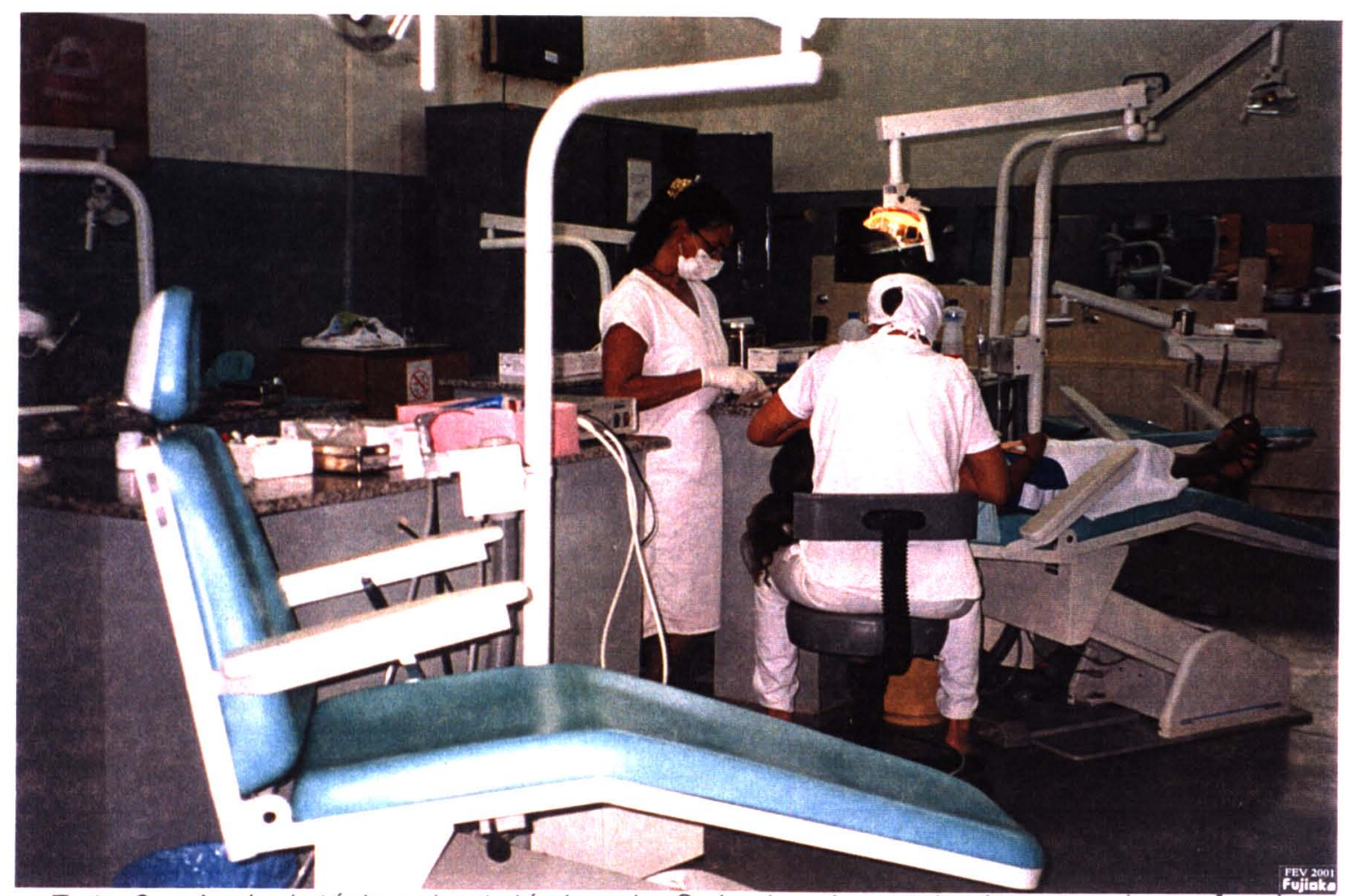

Foto 6 - Ambulatório odontológico do Cais das Amendoeiras, tendo ao fundo a

pia com torneiras e espelho utilizados para escovação supervisionada 


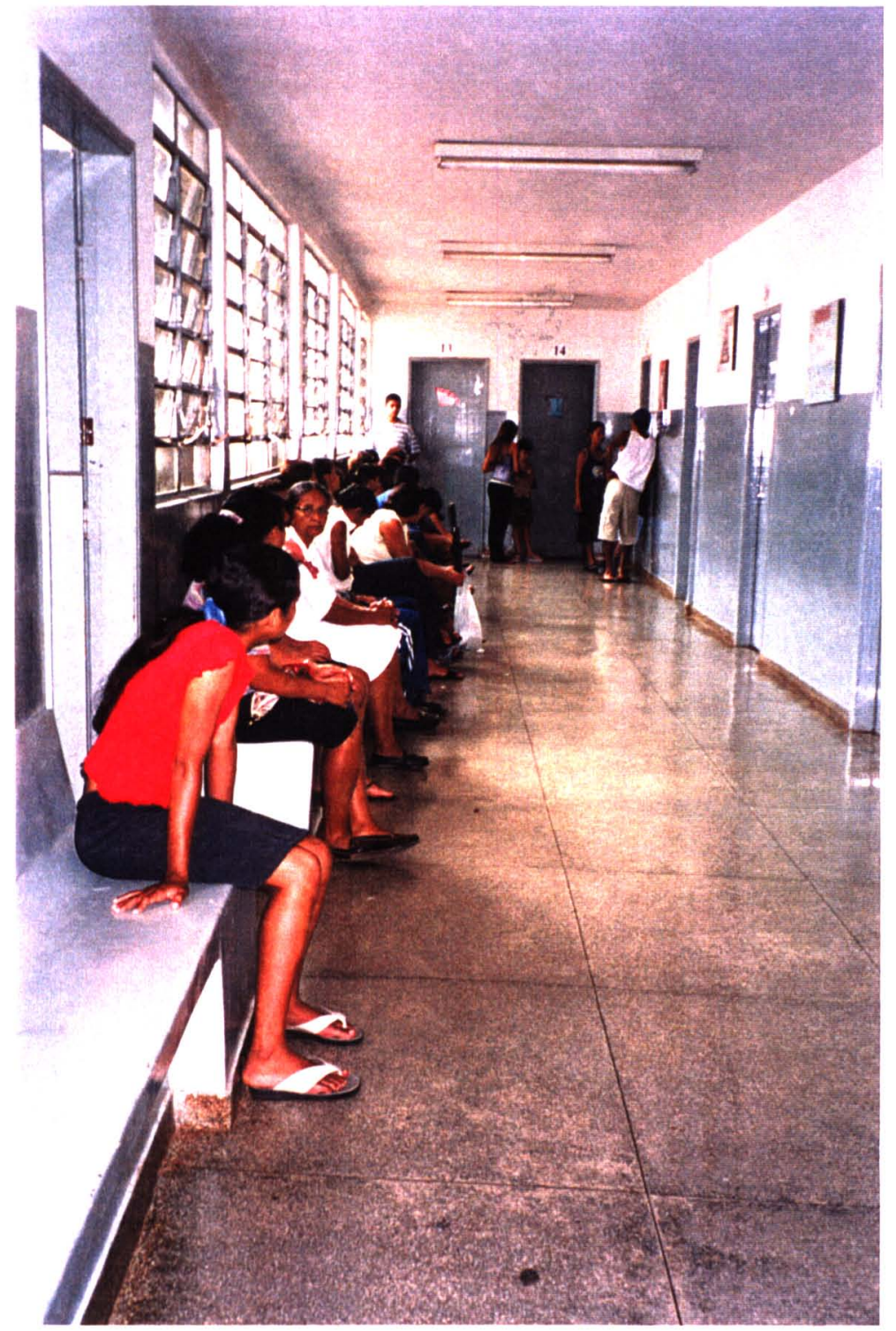

Foto 7 - Corredor da unidade sendo utilizado como sala de espera. Notese que a entrada para o ambulatório odontológico a última sala à esquerda, no final do corredor. 


\section{2 - PROCEDIMENTOS METODOLÓGICOS}

Trata-se neste item dos procedimentos metodológicos adotados nesta pesquisa, abordando um pouco das principais concepções que thes dão suporte teórico, bem como da forma como esta pesquisadora os entendeu e colocou em prática. 


\subsection{1 - LEVANTAMENTO BIBLIOGRÁFICO}

O levantamento bibliográfico sobre o assunto a ser tratado deve ser sempre um dos primeiros passos a serem dados por qualquer pesquisador. É de fundamental importância procurar saber o que já foi abordado naquela área e de que forma isto foi feito.

Para ALMEIDA Jr. (1995), a pesquisa bibliográfica "é a atividade de localização e consulta de fontes diversas de informação escrita, para coletar dados gerais ou especificos a respeito de um determinado tema."

QUIVY \& CAMPENHOUDT (1992) colocam a existência do que eles chamam de "três atos do procedimento" em pesquisa, estes são a ruptura, a construção e a verificação. Para estes autores, a leitura se apresenta como importante fase na ruptura com idéias que trazemos as quais, em grande parte, "se inspiram nas aparências imediatas ou em posições parciais." A ruptura se constitui, assim, no primeiro ato do procedimento científico. Estes autores afirmam que:

"Quando um investigador inicia um trabalho, é pouco provável que o assunto tratado nunca tenha sido abordado por outra pessoa, pelo menos em parte ou de forma indireta. Tem-se freqüentemente a impressão de que 
não há 'nada sobre o assunto', mas esta opinião resulta, em regra, de uma má informação. Todo o trabalho de investigação se inscreve num continuum e pode ser situado dentro de, ou em relação a, correntes de pensamento que o precedem e influenciam."

Dentro desta lógica em que a ruptura com o antigo e a construção do novo se dão de modo simultâneo, é preciso ter claro que a pesquisa bibliográfica deve se estender ao longo de praticamente todo trabalho, já que o objeto vai sendo definido e construído através de múltiplas e sucessivas aproximaçōes. Deste modo, sempre que ocorre uma aproximação a este objeto, um novo aspecto é vislumbrado e, portanto, novas buscas podem e devem acontecer.

Neste sentido, pode-se claramente perceber que $\circ$ levantamento bibliográfico é uma etapa da pesquisa que tem seu início coincidente com o inicio da pesquisa propriamente dita, isto quando não o antecede, já que a delimitação mesma do tema da pesquisa depende dele. Já o seu final é, na maioria das vezes, determinado pela necessidade cronológica que o pesquisador tem de por um ponto final em suas atividades, ou seja, é preciso que seja estabelecido um momento a partir do qual se para de inserir novas referências bibliográficas. Isto porque inúmeros trabalhos surgem a cada dia e, com o advento dos sistemas de busca eletrônica, o acesso a estes trabalhos tem sido muito facilitado.

Quanto mais se lê sobre um determinado tema, maior é o número de aspectos que se mostram interessantes de serem abordados. É preciso, portanto, que o pesquisador não perca de vista os objetivos traçados inicialmente para que consiga o recorte proposto dentro do tema. 
No caso específico desta Tese, é fundamental recordar que os temas "adolescência" e seus correlatos têm sido amplamente abordados das mais diferentes formas possiveis. O grande interesse que desperta parece estar relacionado com a ligação à própria vida e ao cotidiano de todos os seres humanos que passam por esta fase e convivem com outros que estão passando por ela. Isto fez com que a tarefa de manter a pesquisa voltada para um recorte específico se tomasse extremamente árdua. Por outro lado, tornou-a muito mais fascinante na medida em que, paralelamente às leituras, sucedia-se o processo de des-velamento do universo dos adolescentes.

Pode-se dizer que no processo de elaboração desta tese aconteceram três fases distintas de levantamento bibliográfico. A primeira se deu previamente à ida ao campo. Constituiu-se em um levantamento mais amplo com o intuito de uma aproximação inicial aos assuntos que se mostravam importantes para a definição do quadro geral do tema proposto.

A segunda fase aconteceu simultaneamente à ida da pesquisadora ao campo. Esta fase se constituiu na leitura das referências indicadas pelos próprios profissionais, sujeitos da pesquisa, além daquelas leituras que surgiram em decorrência de novos aspectos vislumbrados.

Por fim, houve uma terceira fase, quando se buscou encontrar novos trabalhos referentes ao tema. Estes incluíram não apenas novas publicações, mas também aquelas que, mesmo com data de publicação anterior ao início da pesquisa, não haviam sido encontradas antes.

Naturalmente inúmeros trabalhos consultados não são citados aqui como referências bibliográficas. Isto não significa, de modo algum, que não tenha sido atribuída a eles a devida importância. O fato é que é preciso selecionar apenas um número limitado de trabalhos para as citações, tendo em vista os limites 
deste tipo de trabalho acadêmico. Então, com isto em mente, foi feita uma opção por aqueles que pareceram estar mais diretamente ligados à temática aqui desenvolvida. 


\subsection{2 - ENTREVISTAS}

A opção pela realização de entrevistas com os adolescentes e com os profissionais da SMS teve como um de seus principais objetivos incorporar a este trabalho elementos que tivessem origem diretamente nas pessoas que são alvo e que executam as ações e que, por isto mesmo, estão mais freqüentemente sentindo os resultados destas ações.

HAGUETTE (1987) oferece a seguinte definição de entrevista:

"A entrevista pode ser definida como um processo de interação social entre duas pessoas na qual uma delas, o entrevistador, tem por objetivo a obtenção de informações por parte do outro, o entrevistado."

Esta autora alerta para os viéses sempre presentes nas entrevistas e cujas fontes se localizam tanto no próprio pesquisador quanto em fatores externos a este (como o roteiro utilizado) além do entrevistado e na situação interacional entre entrevistador e entrevistado. Sendo o viés um fenômeno universal, o pesquisador precisa "conhecê-lo em todas as suas nuanças para poder prevenir - quando for possivel - a sua ocorrência." 
Poder-se-ia ter optado por outras técnicas de mais rápida aplicação e tratamento de resultados mais fácil e objetivo como o questionário, por exemplo. Segundo RUDIO (1989): "Tanto o questionário como a entrevista servem para obter informações que não podem ser colhidas através de outros meios." Mas isto, de certa forma, excluiria a própria voz dos entrevistados, o que poderia ter resultado em um certo "empobrecimento" dos dados obtidos. De fato, a fala dos entrevistados com as ênfases, expressões características e silêncios, mostrou-se de uma extrema riqueza. Vários aspectos de grande importância para o tema surgiram e estes certamente não estariam presentes no caso de um questionário fechado, previamente construido.

Como a questão central deste trabalho não passava por uma análise meramente quantitativa, mas sim pela busca da valorização de todos os aspectos que tivessem importância para os sujeitos da pesquisa, optou-se pelas entrevistas abertas, embora estivesse claro que estas seriam de uma complexidade muito maior quando da análise posterior, mas seguramente infinitamente mais ricas para captar a realidade da forma como é percebida pelos entrevistados e este era o interesse desta pesquisa.

Neste sentido, MINAYO (1994) aborda a questão do roteiro das entrevistas da seguinte forma:

"O roteiro da entrevista difere do sentido tradicional do questionánio. Enquanto este último pressupõe hipóteses e questões bastante fechadas, cujo ponto de partida são as referências do pesquisador, o roteiro tem outras caracteristicas. Visando apreender o ponto de vista dos atores sociais previstos nos objetivos da pesquisa, o roteiro contém poucas questões. Instrumento para orientar uma 'conversa com finalidade' que é a entrevista, ele deve ser o facilitador de abertura, de ampliação e de aprofundamento da comunicação." 
A intenção foi a de formular um roteiro de entrevistas que fosse flexivel, mas que permitisse abordar os temas julgados de maior importância. O roteiro inicial serviu de base a todas elas, porém, cada entrevista teve características próprias em função da maior ou menor ênfase dada pelo entrevistado a l'm ou outro tópico abordado. $O$ que se buscou foi que as falas não fossem tolhidas para caberem no roteiro prévio, ao contrário, buscou-se estimular aqueles tópicos que, mesmo não tendo sido previamente pensados pela pesquisadora, pudessem aparecer por serem julgados como importantes para os entrevistados.

Estas entrevistas foram gravadas e, é bom lembrar, o uso deste recurso sempre gera uma inibição inicial no entrevistado, mesmo diante da garantia de que todas as informações ali contidas seriam utilizadas exclusivamente para os fins da pesquisa e, para os adolescentes, sem identificação dos autores das respostas. No caso dos profissionais, após alguns minutos de gravação essa estranheza e timidez inicial foram diminuindo e permitindo um maior aprofundamento nas questōes do conteúdo da própria entrevista.

Já os adolescentes se mostraram, em sua maioria, bastante tímidos. No entanto não se pode atribuir este fato exclusivamente ao uso do gravador. Isto pode ter acontecido devido a vários outros fatores, entre eles o fato de ser este o primeiro contato entre o entrevistado e a entrevistadora. Também existiu o fato de que as entrevistas foram desenvolvidas em um ambiente não muito familiar a eles, pois foram conduzidas em uma sala com um consultório odontológico que não estava sendo utilizado e que não era aquela sala usualmente freqüentada por eles (foto 8). Pode-se também pensar na estranheza mesmo da situação de estar sendo entrevistado, o que, convenhamos, não é um fato muito corriqueiro na vida dos adolescentes em questão. Outro ponto a ser considerado é o próprio desconhecimento da 
natureza e dos conteúdos das perguntas formuladas. Do mesmo modo, podese pensar que a timidez observada seja mesmo uma das características dos adolescentes que procuram o serviço odontológico da unidade de saúde. O que pode ainda ser considerado é que esta característica seja fruto da combinação de todos estes fatores, o que é, talvez, o mais provável.

O consultório odontológico, usualmente utilizado para atendimento de urgências no CAIS, foi escolhido para realizar as entrevistas com os adolescentes por ser a única sala da unidade que poderia ser usada com as portas fechadas e sem interferência de outras atividades, uma vez que nos horários escolhidos para tal fim não havia tal tipo de atendimento.

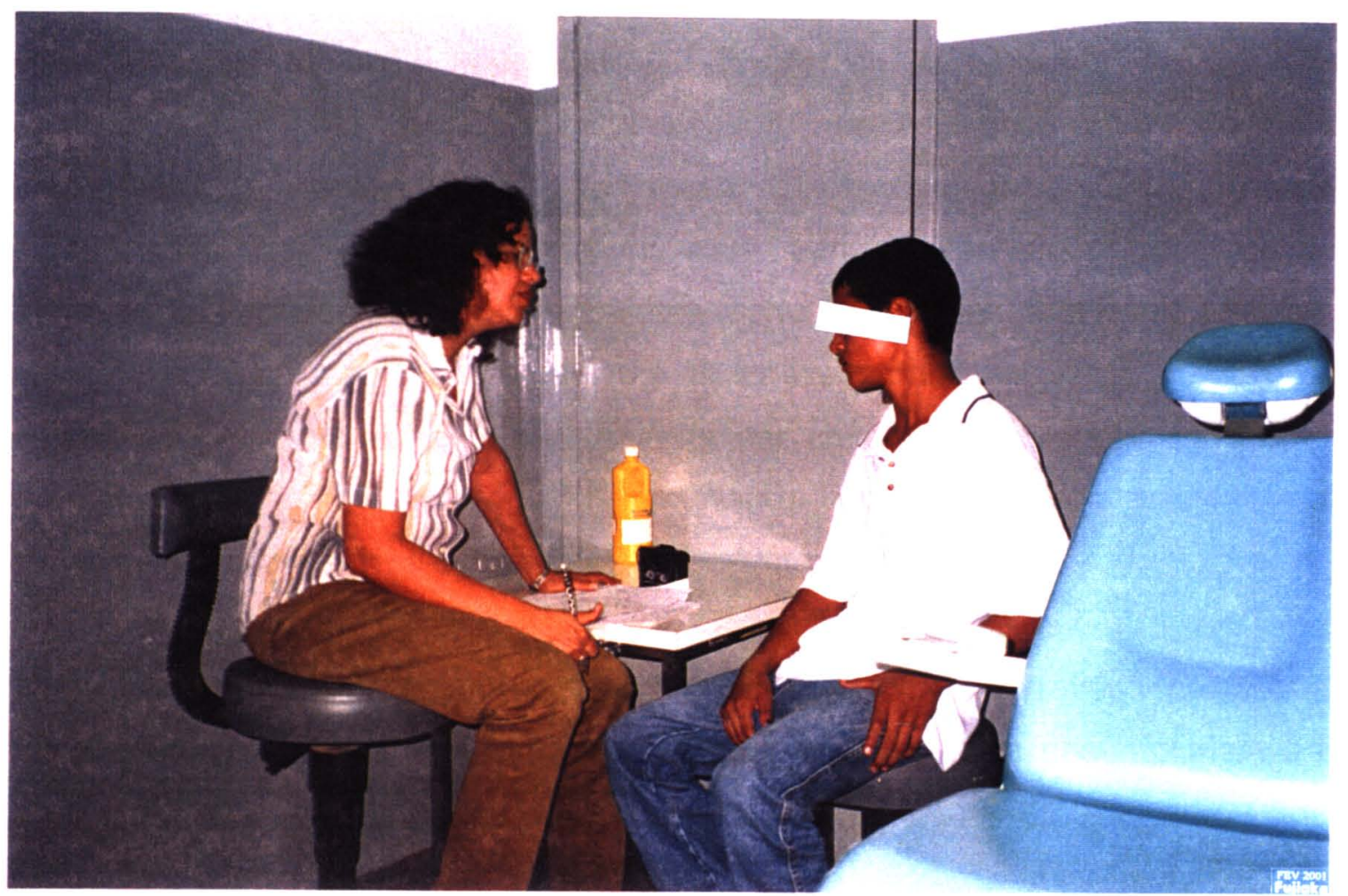

Foto 8 - Um dos adolescentes sendo entrevistado no consultório odontológico destinado ao atendimento de urgências. 
Ainda no que se refere aos adolescentes, cabe ressaltar que foram tomados vários cuidados no que diz respeito ao contato inicial. Sobre a importância deste contato para a realização de entrevistas, RUDIO (1989) afirma que:

"Quanto à entrevista, costuma-se insistir no contato inicial entre entrevistador e entrevistado como sendo de grande importância para motivar e preparar o informante, a fim de que suas respostas sejam realmente sinceras e adequadas."

Este contato com os adolescentes se deu sempre a partir da apresentação de uma Técnica em Higiene Dental (THD) da unidade, com a qual os adolescentes já estavam familiarizados. Este aconteceu sempre individualmente $e$ foi respeitado o desejo do adolescente de se fazer acompanhar pela mãe ou outra pessoa que estivesse com ele. Estas entrevistas acompanhadas, ao serem analisadas, se mostraram muito diferentes das demais, tendo inclusive várias intervenções dos adultos presentes, influenciando e alterando as respostas obtidas. Isto levou à decisão, por parte da pesquisadora, de não utilizá-las para inclusão no corpo deste trabalho, embora esse fato já poderia ser considerado um resultado em si mesmo, ou seja, há uma nitida mudança na postura dos adolescentes quando na presença de um adulto responsável.

Também se buscou sempre esclarecer todas as razões pelas quais aquelas entrevistas estavam acontecendo, como elas se desenrolariam e de que forma seriam utilizadas posteriormente.

No que diz respeito aos profissionais, estes se mostraram bastante abertos a participar deste estudo. Aliás, o que pode ser percebido é que eles, 
na verdade, ansiavam por uma oportunidade semelhante, onde pudessem expressar suas opiniões. Todas as entrevistas foram realizadas no próprio local de trabalho do entrevistado, ou seja, um local bastante familiar. Este pode ter sido um dos fatores que contribuiram para que eles se sentissem mais à vontade para se manifestarem. No caso dos cirurgiōes-dentistas e da Técnica em Higiene Dental da unidade foi utilizado o espaço do ambulatório (foto 9) odontológico, logo após o atendimento. Os demais profissionais foram entrevistados em suas próprias salas de trabalho.

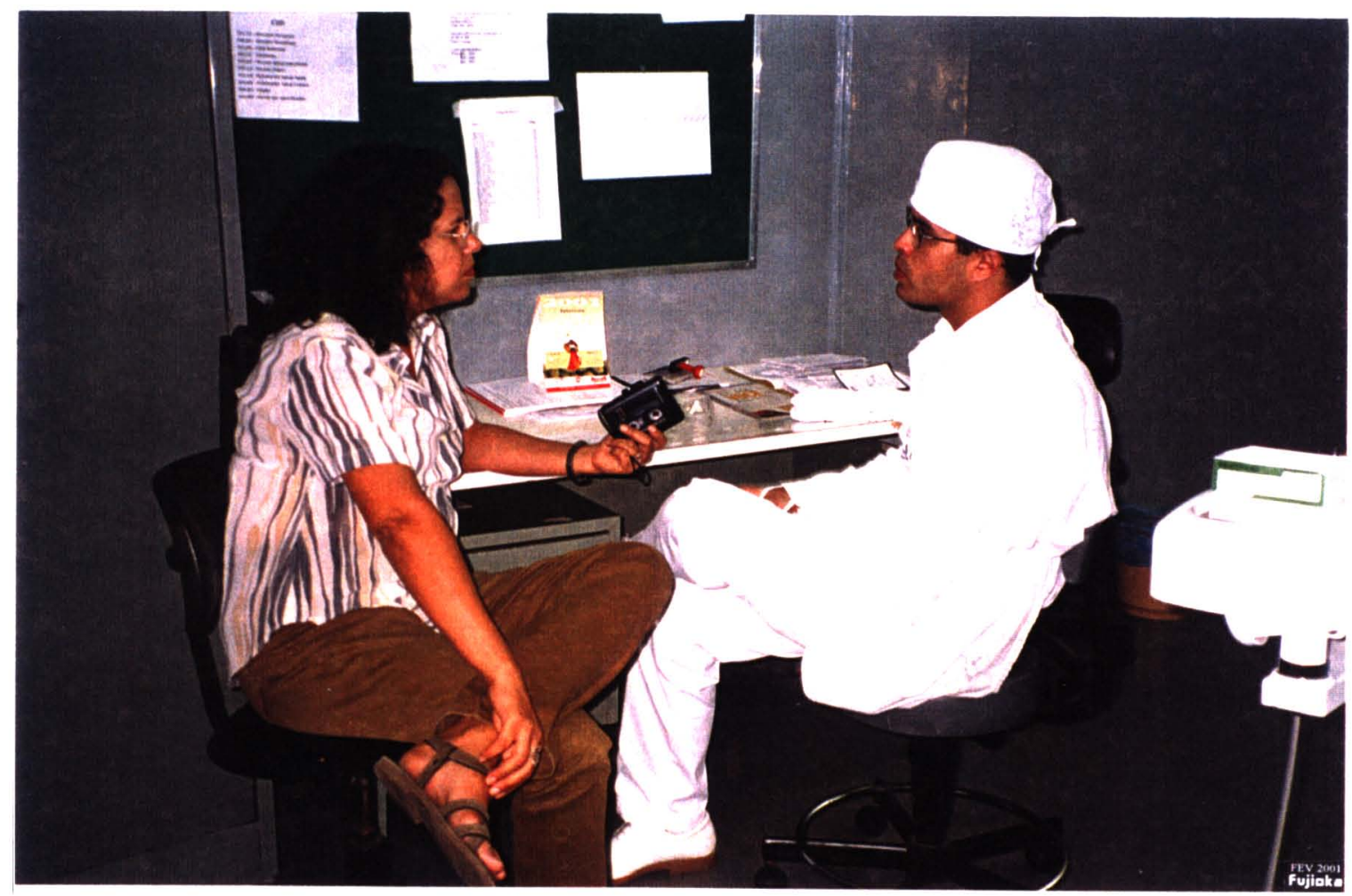

Foto 9 - Um cirurgião-dentista sendo entrevistado no ambulatório odontológico do CAIS das Amendoeiras. 
Todas as entrevistas foram transcritas na integra e apenas não estão anexadas a este trabalho em função da extensão e volume, porém, encontramse à disposição para consulta. Após a transcrição estas foram lidas várias vezes e analisadas pela pesquisadora para extrair das falas dos entrevistados as principais observaçōes, dificuldades, barreiras, elementos facilitadores e sugestōes que pudessem ser importantes para o desenvolvimento do trabalho.

O passo seguinte foi a criação de categorias de análise que pudessem servir de instrumentos para destacar os aspectos mais relevantes e agrupar os assuntos, facilitando a discussão e posterior leitura. Ao se criar estas categorias há uma natural ênfase em aspectos que são julgados mais importantes, traduzindo o olhar da pesquisadora que, nesse momento, se coloca como parte integrante da pesquisa. Evidentemente muitas questões colocadas pelos entrevistados ficam de fora, mas a inclusão de todas tornaria este um trabalho extremamente extenso. Em um primeiro momento, foram identificadas mais de 40 possiveis categorias de análise que foram reduzidas às presentes neste trabalho. Assim, o resultado final mostra quase que uma conjunção das concepções e percepções dos entrevistados e da pesquisadora com todas as leituras e discussões ocorridas ao longo do processo de pesquisa.

Após discutir o assunto com vários profissionais da SMS ligados ao tema em questão, foram sugeridos alguns nomes de profissionais para serem entrevistados. Destes foram selecionados sete profissionais que poderiam traduzir as questões aqui postas. A estes foi adicionado o nome de mais uma profissional que surgiu em todas as falas daqueles funcionários do nivel central, mais familiarizados com a questão do adolescente, que foi o da Profa Eleuse, diretora da Faculdade de Medicina da UFG. Assim a lista de profissionais entrevistados foi a seguinte:

\footnotetext{
- Todos os profissionais foram esclarecidos sobre os propósitos desta pesquisa e concordaram com a divulgação de seus nomes, cargos que ocupavam no momento e utilização das fotografias e entrevistas concedidas para os fins deste trabalho. A apresentação dos nomes
} 
1) Profa Eleuse Machado de Britto Guimarães - Diretora da Faculdade de Medicina da Universidade Federal de Goiás (FM/UFG), uma das fundadoras, em 1983, do Núcleo de Estudos das Questões do Adolescente no Departamento de Pediatria do Hospital das Clínicas da FM/UFG, em 1985 participou da implantação do Ambulatório Para Adolescentes no mesmo hospital e da criação do Núcleo de Estudos e Coordenação de Ações da Saúde do Adolescente - NECASA, hoje ligado à Pró-Reitoria de Extensão da UFG;

2) Maria Claúdia Honorato da Silva e Souza - Nutricionista, chefe da Divisão de Saúde da Mulher, da Criança e do Adolescente da Secretaria Municipal de Saúde de Goiânia;

3) Lucimar Dias Barbosa - Assistente Social do Programa de Saúde da Mulher da Criança e do Adolescente, atua no nivel central da SMS;

4) Marli Moreira Barbosa - Diretora Técnica do Cais Amendoeiras;

5) Maria Aparecida Ferreira - Enfermeira, Supervisora de Enfermagem do Ambulatório do CAIS das Amendoeiras;

6) Maria Fernanda de Carvalho - Dentista no CAIS das Amendoeiras;

7) Sérgio Leão Lobo de Almeida - Dentista no CAIS das Amendoeiras;

8) Eunice Rocha Caetano - Técnica em Higiene Dental (THD) responsável pelo agendamento na odontologia, há 8 anos no CAIS.

e cargos ocupados foi julgada importante para ilustrar o grau de comprometimento e conhecimento a respeito das questões propostas. 
Quanto aos adolescentes*, foram inicialmente realizadas quatro entrevistas que foram utilizadas como pré-teste. O passo seguinte fol a adequação do roteiro, após o que, foi dado início à fase das entrevistas utilizadas nesta pesquisa. Das 14 realizadas, 3 foram excluidas das anáıses finais, sendo que duas o foram porque os acompanhantes dos adolescentes insistiram em estar presentes durante a realização das mesmas, o que claramente gerou desconforto aos adolescentes, interferências $e$, provavelmente, alteração das respostas. A terceira excluida o foi porque, provavelmente por excesso de timidez, o adolescente apenas emitiu respostas extremamente curtas, monossilábicas, às vezes. Assim a análise final foi feita com base nas respostas dos 11 entrevistados listados abaixo:

1) L, 15 anos, sexo feminino, estudante da $8^{a}$ série no turno matutino. Não trabalha e a última vez que foi ao dentista já faz mais de 3 anos, no próprio CAIS. Nāo tem nenhum tipo de atendimento odontológico na escola;

2) M, 12 anos, sexo feminino, estudante da $5^{\text {a }}$ série no turno matutino, não trabalha. Última vez que foi ao dentista: "há uns seis meses no dentista do postinho." Na escola não tem atividade relativa à saúde bucal;

3) K, 16 anos, sexo feminino, estudante da $7^{\text {a }}$ série no tumo matutino, mora perto da unidade e não trabalha. Última visita ao dentista: 3 anos atrás no próprio CAIS;

\footnotetext{
- Todos os adolescentes, assim como seus acompanhantes, foram esclarecidos dos propósitos desta pesquisa e concordaram com a realização das entrevistas e o uso posterior para os fins a que se destina. Suas identidades foram preservadas, portanto eles são identificados apenas através da primeira letra do nome e idade.
} 
4) G, 16 anos, sexo feminino, estuda na $8^{\text {a }}$ série no periodo noturno, trabalha como babá e é moradora do bairro. Última visita ao dentista: menos de um ano na Faculdade de Odontologia, onde fez restaurações e tratamento endodôntico;

5) E, 16 anos, sexo feminino, estudante da $7^{\mathrm{a}}$ série, trabalha como babá. Última visita ao dentista: menos de 1 ano, dentista do CAIS;

6) T, 16 anos, sexo masculino, cursa a $4^{a}$ série, periodo matutino, trabalha em fazenda onde "faz de tudo, até plantação". Última visita ao dentista: há uns dois anos no CAIS onde fez "extração e obturação, canal tinha que fazer, mas não teve como ir no lugar indicado por "eles" e teve que arrancar o dente";

7) E, 17 anos, sexo feminino, parou de estudar na $6^{a}$ série (para trabalhar, pretende voltar a estudar no próximo ano), trabalha como acompanhante $\mathrm{e}$ arruma casa. Última visita ao dentista foi recente, há menos de um mês porque está "fazendo tratamento com aparelho em dentista particular", e outros tratamentos como restaurações e extrações são feitos no CAIS;

8) N, 14 anos, sexo feminino, não trabalha, cursa a $7^{\mathrm{a}}$ série, período noturno. Última visita ao dentista há 6 meses, CAIS;

9) M, 13 anos, sexo feminino, cursa a $7^{\text {a }}$ série no período diurno. Última visita ao dentista foi há mais ou menos 6 meses no CAIS, mas "trata também particular para o aparelho";

10) C, 14 anos, sexo masculino, cursa a $7^{\text {a }}$ série no periodo vespertino, não trabalha. Última visita ao dentista foi há 8 meses no próprio CAIS, nunca tratou em serviço particular; 
11) J, 14 anos, sexo feminino, cursa a $6^{\mathrm{a}}$ série. Última vez que visitou um dentista foi há mais de 5 anos neste mesmo CAIS. Não trabalha, mas pretende para "juntar um dinheiro para por aparelho"; 


\subsection{3 - OBSERVAÇÕES PESSOAIS}

A observação pode ser considerada como ponto de partida para o processo de compreensão da realidade. De um modo geral, é da observação que lança mão todo ser humano para se aproximar do mundo que o cerca. Isto não significa que esta aproximação da realidade se dê sem interferências daquilo que já se traz no momento da observação. Evidentemente os "filtros" são muitos, cabe a quem se propõe fazer pesquisa de maneira conseqüente, expor pelo menos os principais destes filtros, explicitando seus objetivos, limites e marcos conceituais, para que quem o ouve ou lê possa tirar também suas próprias conclusões. Sobre este aspecto da observação, é interessante a classificação apresentada por PÁDUA (1995) diferindo a observação espontânea, feita empiricamente em quase todos os momentos da vida do ser humano, do que é chamado por ele de observação sistemática, realizada com um propósito científico claro e específico:

"Nosso conhecimento do mundo físico e do mundo social se realiza a partir da observação espontânea, informal ou assistemática; registramos os fatos observados a partir de nossa experiência, cultura, 'visão de mundo', tentando buscar uma explicação para a realidade e as relações entre os fenômenos que a compõem. 
Quando falamos da observação como fonte de dados para a pesquisa, queremos dizer que a partir do momento em que o pesquisador se interessa pelo estudo de um dado aspecto da realidade, a observação espontânea deve ser venificada através da observação sistemática, para que se elabore então o conhecimento científico daquele aspecto do real que se nuer conhecer.

Neste sentido a observação sistemática é seletiva, porque o pesquisador vai observar uma parte da realidade, natural ou social, a partir de sua proposta de trabalho e das próprias relações que se estabelecem entre os fatos reais."

É a observação pessoal, realizada de maneira sistemática que permite a captação de vários aspectos que podem, inclusive, servir de orientação básica para a execução de outras técnicas de pesquisa que a complementem.

Foi a partir da observação pessoal que vários itens concementes à estrutura e processos das atividades na unidade pesquisada puderam ser captados e transformados em dados que ajudaram a compor o quadro geral desta pesquisa.

Para RUDIO (1989): "No sentido mais simples, obsenar é aplicar os sentidos a fim de obter uma determinada informação sobre algum aspecto da realidade."

Uma das necessidades deste trabalho foi a de desenvolver a observação direta in loco das atividades, relacionadas ou envolvendo adolescentes, que são realizadas regularmente no CAIS, especialmente aquelas do serviço odontológico, para uma maior e melhor compreensão da realidade posta. Por esta razão foram observadas as atividades educativas realizadas pelos profissionais e por estudantes estagiários, as atividades de escovação 
supervisionada, realizadas pelos dentistas e THD e as atividades clínicas. Foram também observadas a forma como os pacientes são recebidos na portaria, o agendamento e o espaço de espera no corredor da unidade.

A intenção foi a de observar os funcionários durante suas atividades cotidianas, registrando a forma como são encaminhadas as atividades da unidade, especialmente quando envolvendo adolescentes.

Na descrição de CRUZ NETO (1994):

"A inserção do pesquisador no campo está relacionada com as diferentes situações da observação participante por ele desejada. Num pólo, temos sua participação plena, caracterizada por um envolvimento por inteiro em todas as dimensões da vida do grupo a ser estudado. Noutro, observamos um distanciamento total de participação da vida do grupo, tendo como prioridade somente a observação. Ambos os extremos mencionados envolvem riscos que devem ser avaliados antes de serem adotados.

Entre esses pólos extremos encontramos variações da técnica. Uma dessas variações diz respeito ao papel do pesquisador enquanto participante observador. Nessa situação, o pesquisador deixa claro para si e para o grupo sua relação como sendo restrita ao momento da pesquisa de campo. Nesse sentido, ele pode desenvolver uma participação no cotidiano do grupo estudado, através da observação de eventos do dia-a-dia. Outra vaniação se refere ao pesquisador enquanto observador participante. Isso corresponde a uma estratégia complementar às entrevistas, sendo que essa observação se dá de forma rápida e superficial.

Essas variações descritas só podem ser concebidas para fins de análise. Na realidade, nenhuma delas ocome puramente, salvo em condições especiais."

Outra modalidade de classificação em que podem ser enquadrados os distintos momentos de observação que foram desenvolvidos nesta pesquisa, é 
aquela adotada por GIL (1994) que faz a diferenciação entre observação participante e observação simples, definindo esta última:

"Por observação simples entende-se aquela em que o pesquisador, permanecendo alheio à comunidade, grupo ou situação que pretende estudar, observa de maneira espontânea os fatos que ai ocorrem. Neste procedimento o pesquisador é muito mais um espectador que um ator."

$E$, ainda segundo este mesmo autor, a observação participante pode ser definida da seguinte forma:

“A observação participante, ou observação ativa, consiste na participação real do observador na vida da comunidade, do grupo ou de uma situação determinada. Neste caso, o observador assume, pelo menos até certo ponto, o papel de membro do grupo. Dai porque se pode definir observação participante como a técnica pela qual se chega ao conhecimento da vida de um grupo a partir do interior dele mesmo."

O que aconteceu nesta pesquisa não pode ser classificado de observação simples, da forma como descrita pelos autores. Aproxima-se muito mais daquela chamada de observação participante, até porque, sendo a pesquisadora conhecida dos funcionários da unidade, docente da Faculdade de Odontologia da UFG e uma das componentes do Grupo Gestor do PROLESTE, sua participação nas atividades cotidianas é usual e, de certo modo, esperada pelos profissionais da unidade. Em vários momentos nos quais a pesquisadora estava com o propósito de ficar apenas observando, colocando-se da forma mais neutra possivel nas atividades em curso, sua participação foi requerida por algum funcionário ou estudante ali presente. Isso não chegou, contudo, a comprometer a qualidade das observações. Ao contrário, a avaliação que pode ser feita é a de que foi um benefício, já que, identificada com o grupo que 
desenvolve atividades na unidade, a presença da pesquisadora não altera a forma como as ações são desenvolvidas. Este fato tomou as observações realizadas mais confiáveis no sentido de estarem sendo feitas a respeito do modo rotineiro para os profissionais ali atuantes. 


\subsection{4 - ANÁLISE DOCUMENTAL}

Para se conseguir o conhecimento em qualquer área é imprescindivel que se procure obter a maior quantidade de informações possiveis a respeito do tema em questão. Para SEVERINO (1986):

“O saber constitui-se pela capacidade de reflexão no interior de determinada área do conhecimento. A reflexão, no entanto, exige o domínio de uma série de informações. (...) Essa informação só pode se adquirir através da documentação realizada criteriosamente."

Deveria ser norma de qualquer serviço, mas especialmente dos serviços públicos, a realização e organização de sua documentação de forma criteriosa, de modo a permitir não só a avaliação das ações, mas a possibilidade de que todos os pesquisadores pudessem recorrer a esta para poder se apropriar da maior quantidade possivel de informações. Nos serviços públicos de saúde do Brasil, contudo, um fenômeno bastante interessante costuma ocorrer. Se por um lado estes são pródigos na colheita de dados numéricos, referentes a atividades clínicas que implicam repasse de verbas, por outro não costumam agir do mesmo modo com relação a outros dados, tais como o registro de 
atividades educativas. Assim, neste trabalho ficou confirmada a idéia inicial de que poucos relatórios escritos seriam encontrados no que se refere a esta área.

Mesmo assim, foi feito um levantamento de documentos, projetos e programas da Secretaria Municipal de Saúde de Goiânia referentes ao asc unto em questão, isto é, a saúde do adolescente, na tentativa de se encontrar dados que contribuíssem para o trabalho. Porém, para tal propósito, este levantamento se mostrou infrutifero, uma vez que tais dados são inexistentes. $A$ atenção ao adolescente é uma das atividades da Divisão de Saúde da Mulher, da Criança e do Adolescente, sendo que as prioridades são claramente a mulher e a criança, não existindo nenhum programa específico que fosse do interesse desta pesquisa. Este fato ficou também evidenciado quando das entrevistas com os profissionais que relataram, com suas próprias palavras, 0 que já havia sido observado (ver item específico).

Por esta razão a análise documental teve que se restringir à leitura de alguns documentos do Ministério da Saúde e manuais educativos utilizados pelo NECASA. 


\section{6 - RESULTADOS E DISCUSSÃO}

Neste capitulo são apresentados os resultados agrupados em dois itens: os profissionais e os adolescentes do CAIS.

As falas dos entrevistados não estão apresentadas em sua integra nem na ordem direta em que foram proferidas. Julgou-se que ficaria melhor se fossem criadas categorias analíticas para a análise e apresentação dos resultados. Estas categorias foram concebidas tendo em vista os objetivos da presente pesquisa.

A parte mais árdua foi, seguramente, abrir mão de vários trechos de falas que, embora sendo muito ricos e esclarecedores, não diziam respeito diretamente ao tema pesquisado. Inicialmente, ao serem feitas as primeiras leituras das entrevistas, foram pensadas 28 categorias de análise. Evidentemente isso, se não inviabilizasse, tornaria este trabalho por demais extenso. Mas cabe ressaltar que muitas das respostas dadas poderiam estar incluidas em diferentes categorias ou ter trechos abordando aspectos distintos. Os conteúdos das respostas não concernem unicamente à pergunta formulada. Então, após repetidas leituras para familiarização e pensando em tornar o estudo mais objetivo, os achados foram agrupados nas categorias abaixo relacionadas. 
Para os profissionais:

1. caracterização dos adolescentes;

2. concepções que embasam as atividades educativas e estratégias utilizadas;

3. concepções sobre os serviços;

4. recursos humanos;

5. resistências e dificuldades;

6. possibilidades de atuação junto aos adolescentes.

Para os adolescentes do CAIS:

1. caracterização dos adolescentes;

2. percepções sobre o serviço: resistências e dificuldades

3. percepções sobre o serviço: necessidades e possibilidades

4. valores $e$ interesses;

5. saúde bucal e a vida. 


\section{1 - OS PROFISSIONAIS:}

Primeiramente aborda-se a visão dos profissionais. Nesta análise busca-se dar voz aos entrevistados, porém somam-se a esta voz as observações feitas pela pesquisadora. Os trechos de entrevistas escolhidos são reproduzidos em sua integra, buscando não alterar os termos utilizados para alcançar a maior fidelidade possivel. Isto resulta, às vezes, em alguns erros gramaticais e na inclusão de certas expressões coloquiais ou regionalismos que, provavelmente não estariam presentes em caso de um questionário respondido por escrito. No entanto entende-se que, desta forma, consegue-se uma maior aproximação com a intenção de expressão do entrevistado.

\section{0) CARACTERIZAÇÃO DOS ADOLESCENTES}

Nesta categoria foram agrupadas as falas que indicam a forma como os profissionais vêem os adolescentes e a adolescência. Esta é uma categoria fundamental de análise, pois traduz as concepçōes dos profissionais que embasam toda a sua atuação com referência aos adolescentes. 
Quando durante a entrevista o próprio entrevistado não explicitava seu pensamento sobre a adolescência e os adolescentes, uma pergunta (a de número 8 do anexo 2) foi feita, mesmo que variando um pouco sua forma, explicitamente a todos os profissionais: "Como você caracterizaria o adolescente que procura os serviços?" As respostas mostraram que muitas vezes existe uma dificuldade em externar esta concepção, porém ela se evidencia em outros trechos da entrevista mostrando que ela existe, mas talvez por não ser consensual, não é expressa claramente.

De modo geral a referência aos adolescentes é feita com base na faixa etária. Este é o grande fator caracterizador presente nas falas. Várias outras características também foram apontadas pelos entrevistados. Entre elas pode-se destacar o fato de os adolescentes terem muita informação sobre várias áreas da vida, porém, ao que tudo indica, estas não são suficientes para suprir algumas de suas maiores necessidades como sexo, drogas e relações interpessoais. Foi também apontado o fato de serem muito imediatistas, isto é, interessam-se apenas por aquilo que estão vivendo naquele momento; estão numa fase de intensas mudanças corporais e psicológicas, construindo a própria identidade; começam a extrapolar o concreto e a lidar com abstraçōes; demonstram insegurança e necessidade de serem aceitos tanto pelo próprio grupo como pelos adultos; são, de modo geral, críticos, vaidosos, alegres, curiosos e contestadores. No que se refere especificamente aos adolescentes da região estudada, foram considerados carentes em termos sócio-econômicos e sem opção de lazer e de trabalho.

Os trechos de entrevistas a seguir ilustram estes achados.

Assistente Social Lucimar:

COMO VOCÉS CONSIDERAM O ADOLESCENTE? O QUE É ADOLESCENTE? 
Olha, a gente vai pela questão do MS, dos 10 aos 19 anos. Por faixa etária, mas, se você vai trabalhar com um grupo, eu não acho que tem que ser a mesma fala com o de 13, de 10 , de $19 \ldots$

Após alguns minutos, a pergunta é repetida de outra forma:

COMO VOCÉ CARACTERIZARIA UM ADOLESCENTE? DE MODO GERAL, COMO É QUE ELES SÃO? TEM ALGUMAS CARACTERISTICAS PROPRIAS DESSE ADOLESCENTE QUE PROCURA O SERVIÇO?

Exatamente, a gente fala assim, "Nossa, o adolescente tem tanta informação!" porque ele fala, fala, fala... Mas parece que aquela informação que ele precisa, ele não tem. Ele é pouco informado do que ele quer ouvir. Tanto é que a gente observava tanto isso nos grupos que a gente trabalhava assim: temas. " $O$ que é que vocês querem trabalhar?" Vamos supor, AIDS, drogas... Ai eles escolhiam, faziam a votação, então tal dia vamos trabalhar aquele tema. Então se aquele tema interessava pra ele, ele ia mesmo. Acabou aquilo, um outro tema não interessa mais, então acabou. Ele é muito assim, ele age na busca daquilo que ele quer naquele momento. Ele é muito o hoje, ele é muito imediatista. Se ele quer saber de métodos contraceptivos, porque ele já está querendo manter uma relação sexual, ele quer saber ali, naquele momento, acabou, acabou. "Não me vem falar de drogas que eu não tenho nada a ver com isso, eu não mexo com drogas." Ele é muito assim, o que ele quer naquela hora. Então as informações, às vezes chegam até ele, mas, é como se diz, não entra, sabe? Bate e volta. Porque não é o que ele quer saber, ele não está interessado, ele não está vivenciando. Se um dia ele for conviver com um grupo que está mexendo com drogas, ele pode até querer saber informação sobre drogas. Mas se aquilo não faz parte do mundo dele, ele não se interessa. Ele é muito o momento. (...)

Todos os sublinhados feitos nos trechos das entrevistas foram feitos visando destacar partes que mais pareceram significativas à autora deste trabalho. Do mesmo modo as observações que aparecem entre parênteses foram feitas pela autora e o símbolo (...) indica que foi suprimido um trecho da fala. O trecho entre colchetes [] foi inserido pela autora. 
O mesmo acontece com a nutricionista Maria Claudia:

\section{O ADOLESCENTE PARA VOCESS É CONSIDERADO QUEM? QUEM É O ADOLESCENTE?}

De dez a vinte anos, é o que a OMS preconiza.

Já em outra pergunta, discorrendo sobre prevenção, ela faz a seguinte afirmação:

(...) e a prevenção também da questão da saúde mental no grupo de adolescente, já para ajudar na estruturação desse novo ser, porque é a fase da aquisição da identidade. Então é muito importante um psicólogo no grupo de adolescentes, porque ele ajuda nessa questão. Tem adolescentes muito timidos. A questão da mudança corporal que dá uma certa insegurança para o adolescente, ele enxerga isso como uma invasão no seu corpo que ele não consegue deter e também não tem controle nenhum sobre isso.(...)

Mais adiante:

(...) Eu acho que a prevenção voltada para a questão da beleza, daquela coisa que o adolescente gosta, valorizando a questão da auto-imagem. Bem própria para o adolescente.(..)

(...) É uma época que você está deixando do concreto e está abstraindo.(...) Porque o adolescente é critico (..)

Já a chefe da unidade Marli, ao invés de falar das características, fala da atividade mais freqüente:

COMO É QUE SÃO AS CARACTERISTICAS DOS ADOLESCENTES QUE PROCURAM AQUI? COMO VOCE DESCREVERIA O ADOLESCENTE TÍPICO QUE PROCURA O CAIS? 
Na sua maioria são estudantes, estudantes e trabalhadores, alguns trabalhadores.

Maria Aparecida, mesmo sendo uma enfermeira bastante experiente com adolescentes, com atuação nas unidades de saúde, no PROLESTE e no NECASA, alega não conhecer bem o adolescente da região e aborda mais os dados empíricos do atendimento no CAIS:

QUAIS SÃO AS CARACTERISTICAS BÁSICAS DO ADOLESCENTE QUE PROCURA O CAIS?

Bom, a gente está numa região em que o nivel sócio-econômico não é muito favorecido, né? Você vê adolescente com necessidades básicas ainda... por exemplo de saúde oral. $O$ índice de gravidez de adolescente é alto, a gente sabe pela busca, pela procura porque a gente não tem isso ainda quantificado. Nós temos abuso sexual, usuário de drogas... É uma região onde a ociosidade das crianças e adolescentes... falta de opção de lazer, de trabalho.... Eu não conheço com rigor a região. É essa a necessidade de estar fazendo esse diagnóstico, da gente estar acompanhando de perto.

Para Maria Fernanda, dentista da unidade que atua como preceptora dos estudantes de odontologia e é conhecida por sua capacidade de comunicação:

E VOCÉ? COMO VOCÊ VE O ADOLESCENTE QUE PROCURA O SERVIÇO AQUI? COMO ELEE É?

Como nosso grupo é um grupo grande, aqui a gente tem de todo tipo. Tem o adolescente tímido. Teve um menino que chegou ai, com seus 14 anos, ele ficou sentado no banco, com a carteininha no bolso até as 6 horas da tarde. E a gente não o conhecia, ninguém tinha visto ele ainda, e ele ficou, ficou, ficou... Depois, quando sobrou só ele no banco, a gente foi perguntar, ele disse que estava marcado pra hoje. E aí a gente: porque você não chegou e falou? Já tem aquele outro bem rebelde, que mexe em tudo e te fala de tudo e já tem até aquele outro 
que quer te dominar mesmo, sabe? Outro dia tinha um falando assim: "O que é que você vai por na minha boca? Esse negócio tá limpo? Cê vai fazer isso no meu dente? Olha que eu te processo, eu posso procurar não sei quem, não sei quem...Eu te processo heim cara!" Então tem assim... os meninos acharam dificil trabalhar com ele. Mas de modo geral são aqui da região, das escolas que tem módulo, alguns deles já conhecem as THDs que trabalhavam nos módulos, que já faziam parte dos programas antes, então eles já estão familiarizados. Não tem assim grandes problemas não. Teve um extremo ou outro, mas de maneira geral eles se portam bem, não são assim muito tímidos, nem tão... mas, eles são alegres, são alegres.

A THD Eunice, que trabalha com adolescentes não apenas no CAIS, pois em outro período é professora em uma escola da região, na qual ela também reside, mostrou-se particularmente conhecedora das características dos adolescentes em vários momentos da entrevista, mas quando indagada especificamente, não se estendeu muito no conteúdo da pergunta, desviando-se rapidamente do assunto:

COMO VOCE CARACTERIZARIA OS ADOLESCENTES QUE PROCURAM O CAIS, COMO ELES SÃO?

Carentes, mal informados a maiona vem aqui porque o dente já está doendo, ou canal ou extração.(...)

Mas em outro momento da entrevista trouxe dados muito importantes, particularmente sobre a inserção sócio-cultural dos adolescentes:

O QUE VOCE CONVERSA COM OS ADOLESCENTES DAQUI? EM QUE ELES ESTÃO INTERESSADOS ATUALMENTE?

Eu vivo aqui nessa região leste, moro aqui, trabalho aqui e numa escola ali, no Dom Fernando. Eu converso com meus alunos e o interesse deles é trabalhar 
para ganhar dinheiro para ajudar os pais ou para comprar roupas, se manter né?, namorar... Eu acho que o foco deles está nisso mesmo.

E O DINHEIRO QUE ELES GANHAM, VOCE ACHA QUE O ADOLESCENTE ESTÁ INTERESSADO EM GASTAR COM O QUE?

Roupa, calçado, boné bonito, tênis... Porque eles são muito assim, eles vêem as pessoas bem vestidas, então eles se acham inferiores e eles querem pelo menos se vestir como as outras pessoas para serem aceitos. Porque eles já acham que moram aqui nessa periferia, às vezes moram até num barraquinho de Iona lá na beira daquele buracão. Ele pega uma van, vai no centro e vê tanta gente bonita, então ele fica se sentindo muito ruim né?

\section{É UMA QUESTÃO DE SE INTEGRAR MESMO NA SOCIEDADE? É. com certeza.}

A exceção a esta postura foi a resposta dada pela Profa Eleuse, que foi bem objetiva:

QUANDO LEIO OS ARTIGOS TENHO UMA DIFICULDADE É NESSA DEFINIÇÃO DO QUE É O ADOLESCENTE. NA VERDADE VOCÊS TRABALHAM COMO?

É claro. Adolescência não é um período da vida que pode ser muito delimitado, o inicio sim, porque o início da adolescência confunde com o inicio da puberdade. (...) Agora o fim da adolescência é muito variável. O quê que é ser adulto? O quê que é deixar de ser adolescente? Então para evitar essas questões a Organização Mundial de Saúde preconiza, porque nesse período realmente acontecem as principais transformações na adolescência, o periodo que é compreendido entre dez e vinte anos. $\underline{O}$ periodo entre dez e dezenove anos $e$ onze meses a gente considera adolescente, no nosso ambulatório nós atendemos gente dessa faixa etária. 
(...) A adolescência é dividida em fases, por exemplo, os adolescentes da fase inicial, que é de dez a quatorze anos, eles têm um tipo de problema, depois dos quatorze aos dezenove anos já têm mais outros tipos de problemas. Eu tenho uma experiência importante com isso porque a grande procura no meu consultório é nessa primeira fase. Eles vêm com problemas de crescimento, mas não reais, fantasiosos, por falta de entendimento de como acontece o crescimento ncssa fase. Eu atendo no meu consultónio adolescentes normais que são levados pela preocupação da mãe, que acha que o filho não está crescendo ou que a filha está com a menstruação atrasada, mas são nomais. Então ai você faz uma orientação para familia, tenho até um livrinho que chama "Adolescência para pais e professores" que descreve essas questões.

\section{$\left.2^{\circ}\right)$ CONCEPÇÕES QUE EMBASAM AS ATIVIDADES EDUCATIVAS E ESTRATÉGIAS UTILIZADAS}

Todos os entrevistados falaram da própria experiência, de uma maneira que demonstrou a riqueza dos trabalhos desenvolvidos por estes profissionais. Evidentemente existiram alguns aspectos de discordância entre as diferentes falas, o que, longe de prejudicar a qualidade deste trabalho, só veio comprovar a sua importância acadêmica e para o desenvolvimento de ações no serviço.

Um dos pontos que valem ser destacados é a discordância entre as concepções dos profissionais e as normas do serviço. Há, no serviço odontológico da SMS, a determinação de que os usuários só podem ter acesso à atenção clínica mediante a presença obrigatória em uma série de 4 palestras com forma e conteúdo pré estabelecidos. Com exceção de um dos dentistas, Sérgio, que parece concordar com a realização desse tipo de atividade educativa, os demais 
entrevistados mostram posições bem diferentes. Talvez isso se deva ao fato de que o referido dentista não tenha tanta experiência com educação como os demais profissionais. Muito provavelmente, contudo, sua posição seja mais coerente com a maioria dos profissionais da odontologia, já que a prática das palestras ainda é algo muito comum nos programas odontológicos, bem como a vinculação da atenção clínica à presença do usuário nesta atividade. $O$ fato de não se ter a freqüência esperada nesse tipo de atividade, a não ser quando obrigatória, não parece despertar nenhum sentimento de inadequação por parte daqueles que planejam tais atividades. Ao contrário, o recurso utilizado é a autoridade, tanto por parte dos gestores que obrigam os profissionais a cumprirem com esta tarefa, quanto por parte dos dentistas responsáveis com relação aos seus pacientes.

Puderam ser identificados dois tipos de concepções educativas que, claramente estão associadas a determinadas estratégias educativas. A primeira é uma concepção verticalizada, autoritária mesmo. Nas falas dos entrevistados que apresentam esta visão as estratégias citadas foram a palestra, o vídeo, a escovação supervisionada e o álbum seriado, quando referindo-se às atividades desenvolvidas no serviço. Mas este tipo de concepção foi também identificado em referências ao Ministério da Saúde, então as estratégias que surgiram foram o "folder" e um manual de treinamento.

Já nas entrevistas cujas concepções se mostraram mais do tipo participativo, as estratégias associadas foram o treinamento e sensibilização dos recursos humanos envolvidos e, no referente a atividades com os adolescentes, atividades grupais, metodologias participativas de modo geral, adequação de linguagem e brincadeiras ou jogos competitivos. Seguem-se algumas falas que exemplificam o acima exposto.

Cirurgião-dentista Sérgio:

VOCE FAZ ALGUM TRABALHO EDUCATIVO COM OS PACIENTES? 
O trabalho educativo que é feito, ... são realizadas 4 palestras. Antes de entrarem em tratamento eu faço 4 palestras. A assistente social me manda uma lista, normalmente com 20. Esses 20, por exemplo, se é o grupo da segunda feira, na primeira segunda eu reúno todo mundo, explico como é que é o tratamento, como é aqui no CAIS, como é a escovação, que tem que trazer escova, cartão, que não pode faltar, que tem muita gente na fila, ... Inclusive nesse dia e todos os dias, muita gente já sabe e traz escova, eu sempre faço evidenciação e escovação supervisionada. Nas outras segundas feiras, ai tem vídeo, tem mais blá-blá-blá. tem onientação de escovação, orientações gerais... são 4 segundas feiras, são 4 palestras que nomalmente eu gasto meia hora, 40 minutos, uma hora com esses pacientes. São 20 de 6 a 16.

SE ELES VEMM ACOMPANHADOS DE PAIS, ENTRA TODO MUNDO?

Entra. Se quer escutar o que estou falando, entra e escuta também.

\section{E COMO É A RECEPTIVIDADE DESSAS ATIVIDADES?}

Olha, eles têm que se interessar porque eu falo: "Quem não mostrar interesse não vai ter tratamento." Então eu falo assim: "A gente tem uma lista de mais de mil nomes esperando tratamento. Quem eu perceber que não tá dando valor, não está se interessando, não está fazendo a escovação direito, as orientações que eu falo entra por um ouvido sai pelo outro, quem não mostra interesse, falta a palestra, chega atrasado, eu não marco tratamento." Então aí eles vêm certinho.

MAS QUANDO ELES ESTÃO LÁ, ELES FICAM QUIETOS, FAZEM PERGUNTAS, TÊM PARTICIPAÇÃO?

Não, não. Eles prestam atenção porque a gente tem 2 fitas educativas que são interessantes, mas eles não fazem perguntas, não ficam conversando... Se tem alguém voando eu: "Psiu, presta atenção!" Então eu fico em cima, mas participação mesmo eles não têm. De vez em quando um pai ou uma mãe que tem um problema parecido com o que ele viu no video, pergunta, mas é pouco. 
VOCE TEVE ALGUM TREINAMENTO, POR PARTE DA SMS, PARA UTILIZAR ESSES VIDEOS, FAZER ESTAS PALESTRAS?

Não, muito pelo contránio. Eles não dão nada de material. Esse vídeo a gente conseguiu, um pega emprestado com outro... Material que eles deram foi só uns... cartazes..., como é que chama aquilo? Álbum seriado! Álbum seriadn? É assim que chama?

É.

Só um desses e mais nada. Um belo dia eles chegaram aqui e falaram: " $O$. vocês vão ter que dar 4 palestras.", e só, acabou.

Também ficou explicita a deficiência de recursos educativos ou material de apoio para as atividades educativas, bem como de treinamento dos técnicos a quem cabe desenvolvê-las. Estas, a julgar inclusive pelos mapas de produtividade do serviço, ainda não têm, no desenrolar das ações, o destaque dado nas falas dos coordenadores de serviços. Mesmo assim, com todas as controvérsias possiveis sobre a forma das atividades educativas, o nivel de conhecimento dos usuários no que se refere a saúde bucal, parece ter melhorado muito nos últimos anos

Maria Cláudia:

(...)VOCE ACHA QUE AS POLITICAS, A NIVEL NACIONAL ESTÃO ADEQUADAS? OS MANUAIS, O MATERIAL QUE TEM VINDO...

O PROSAD veio, estruturado pelo MS, numa época de vacas magras podese assim dizer. Não foi como o programa da mulher e da criança, que foi uma época do MS que tinha uma equipe enorme, muitos consultores, verba para fazer bastantes manuais, folderes, cartazes, álbuns-seriados e tudo mais. Com o adolescente não teve isso, foi implantado no Ministério da Saúde em 89/90, governo Collor. Nessa época não tinha dinheiro no Ministério, a equipe do 
adolescente dentro do Ministério sempre foi muito pequena, nós não temos muitos materiais que vêm do MS. A gente tem aquele... são normas técnicas, são 3 livretos de nomas técnicas, que em tudo quanto é lugar que você vai falta, não tem em quantidade suficiente para dar para as unidades de saúde. Um conjunto dessas nomas aqui, aquelas bases programáticas que você deve conhecer... e é só, não tem mais nada.

\section{DE LÁ PARA CÁ NÃO VEIO NENHUM MATERIAL, NÃO VEIO NADA?}

Não,... veio um material que é o "Ficar por Dentro", que foi uma fita de video junto com um folderzinho sobre o planejamento familiar destinado ao adolescente com uns cartazes pra você marcar reunião e tal... e só. Esse é o material do MS. Veio uma sugestão de um módulo de treinamento, de sensibilização excelente. Isso a gente faz desde 90, o NECASA fez isso. Mas o MS, não sei se porque é Goiás, não valorizou. Quer dizer, a gente trabalhava com xerox, agora foi impresso. A Universidade imprimiu um material muito bom que não veio do MS. Teve uma época que eles passaram livros pra gente. Eles compraram livros de alguns autores assim... e passaram, não sei se foi na época do treinamento, 90/91, eles passaram um manual de Medicina e Adolescência, umas coisas assim. Passaram pra todo mundo um livro de ginecologia de adolescentes... Iivros, sabe? Eles passavam para as coordenações..

Esta fala explicita, além da indignação com as ações autoritárias e centralizadoras do MS, a escassez de recursos destinados a esta área. Demonstra que este problema não é uma característica da SMS, mas que é a tradução de uma politica pública nacional. Demonstra ainda uma certa perplexidade da entrevistada diante do fato de que as atenções daqueles que ocupam cargos de destaque no nivel ministerial estão sempre voltadas para os mesmos centros de produção, normalmente aqueles localizados nas regiões Sudeste e Sul do Brasil. Mostra ainda que a forma como são gastos os poucos recursos da área, nem sempre atende às necessidades daqueles que estão 
desenvolvendo as ações. O exemplo citado foi o da aquisição e distribuição de livros técnicos, mas, com certeza, muitos outros poderiam ser enumerados.

Ainda sobre a influência das diretrizes ministeriais nas atividades desenvolvidas cabe destaque à fala da assistente social Lucimar:

VOCESS TENTARAM DE ALGUMA FORMA LEVAR AS DIRETRIZES DO MS PARA AS PESSOAS QUE TRABALHAM NAS UNIDADES?

Não, nunca fizemos isso. Eu mesma não tive essa visão, porque no Estado, como eles trabalham mais ligados ao MS, à Divisão de Saúde Da Mulher, Da Criança e do Adolescente, é mais direto. Eles têm até hoje esse treinamento que eles fazem em Goiânia e no interior, de sensibilização com os profissionais de estar trabalhando com os adolescentes. Quando eles faziam esse trabalho, inclusive em várias unidades de saúde que ainda não eram municipalizadas, mas nas unidades de saúde municipais, nós não abordamos isso de estar levando uma coisa do MS. Eles trabalham assim, com as cartilhas, os módulos, são todos voltados para o adolescente, mas sem estar falando que o MS preconiza isso, entendeu? A questão da política de saúde do adolescente não, a política não, de falar dessa forma não.

VOCE ACHA ESTAS POLITICAS ADEQUADAS À REALIDADE DE GOIÂNIA?

Não, eu acho que a gente precisava rever isso. Precisava que cada estado estivesse fazendo parte de uma reunião até mesmo junto com o MS, para você mostrar sua realidade. Ver uma coisa mais concreta para trabalhar junto com o adolescente. Acho muito abstrato, ah, trabalhar a sexualidade, a gravidez, trabalhar isso... E não fica assim uma coisa mais concreta para você. Tem que trabalhar a saúde ocular, a saúde bucal e tal. Mas como? Que jeito? Que recursos vocês vão me dar? É diferente trabalhar uma adolescente grávida e uma mulher grávida. Precisa de recursos, material, etc.... 
Já na fala da Profa Eleuse, que atua com o suporte da Universidade, sem tanta dependência direta de ações governamentais, há a evidência de que diferentes estratégias podem e devem ser tentadas, desde que exista um preparo prévio, uma capacitação daqueles envolvidos:

VOCÊS TÊM TODO ESSE TRABALHO EDUCATIVO QUE ESTÃO DESENVOLVENDO HÁ MUITO TEMPO, ENTÃO HÁ UMA NOÇÃO GERAL DE QUE O ADOLESCENTE NÃO AGÜENTA FICAR MUITO TEMPO PARADO, ELE NÃO GOSTA MUITO DE OUVIR, ELE TEM QUE ESTAR SEMPRE EM ATIVIDADE...

Adolescente não, ninquém. Ai eu acho que seria interessante você conversar com as pessoas que têm feito um trabalho de grupo e têm uma experiência com adolescentes. Não individualmente. Porque eu não gosto de trabalhar assim com adolescente, com fazer palestra, palestra eu não faço. Palestra não adianta. Quando eu sou convidada a trabalhar com adolescentes ai a gente faz metodologia participativa. Por exemplo, eu fui convidada a trabalhar com um grupo de adolescentes sobre sexualidade e foi muito interessante. A gente descobre umas coisas muito interessantes, lá surgiu a questão do homossexualismo e uma adolescente, era a menina mais reacionána que eu já vi, contra, achando que era uma coisa imoral. Para você ver que os adolescentes, às vezes, têm opiniões bem quadradas, por exemplo. E a gente tem até que ter muito cuidado porque você tem que respeitar o adolescente, porque às vezes você tem idéias na sua cabeça que você fala alguma coisa que até choca o adolescente. Por exemplo, eu tenho adolescentes que acham que a vida sexual só tem que ser depois do casamento e eu não vou discutir. Isto é uma questão, um problema dela. Eu vou estimular é isso: você faz aquilo que você acha que está certo.

QUE ASSUNTOS VOCE ABORDA QUANDO VAI TRABALHAR COM ADOLESCENTES?

Eu, pessoalmente, gosto de trabalhar com quem vai trabalhar com o adolescente. Porque eu sou radicalmente contra essa questão de palestra. Eu 
tenho um ponto de vista bastante firmado, é baseado em opinião de gente muito mais experiente que eu. Isso eu não faço. Por exemplo, se você me convidar para fazer uma palestra para adolescentes, eu não vou. Porque, por exemplo, educação sexual, quem tem que fazer educação sexual é quem está trabalhando com ele. Então eu gosto muito de trabalhar com o professor. Eu trabalho com treinamento, uma das nossas funções é treinar pessoal que trabalha com adolescentes.

Aqui a Profa Eleuse expõe com muita firmeza a sua posição de educadora experiente. Sua fala, o conteúdo e a forma com que a emite, demonstra que sua opinião não é fruto de alguma leitura superficial ou modismo. Demonstra ainda a importância atribuída ao treinamento de pessoal, o que parece que vem sendo negligenciado na maioria dos serviços

A dentista Maria Fernanda, que desenvolve atividades educativas não só com os usuários do serviço, mas que tem a responsabilidade de contribuir para a formação do futuro profissional que cumpre estágio sob sua orientação, demonstra familiaridade com as diferentes estratégias educativas. Outro aspecto que se evidencia, quando comparadas as falas dos dois dentistas entrevistados, é que, mesmo diante de normas bastante rígidas da SMS, há espaço para inovações e experimentação de novas propostas. Não fica claro se as atividades realizadas sob sua coordenação, diferentes das preconizadas pelo nivel central, chegam ao conhecimento da chefia na SMS e, se chegam, qual a conseqüência disso.

Maria Fernanda:

VOCE CONHECE ALGUMA ATIVIDADE ESPECÍFICA EM ODONTOLOGIA PARA ADOLESCENTE AQUI NO CAIS?

Não, especifica, não. É lógico que tem aquela palestra educativa e quando tem a maioria de adolescentes, a gente procura fazer voltada pra ele, mas é um programa que atinge de 6 a 16 anos. Então é muito complicado. 
NESSA ATIVIDADE SE TIVER CRIANÇA DE 6 E ADOLESCENTE DE 16 ELES FICAM TODOS JUNTOS?

$\underline{E}$ dificil, complica. É, eles ficam todos juntos, mas assim, não tem como separar... Na verdade era de 6 a 12, depois passou pra 6 a 14, ai colocou pra 6 a 16. Mas sempre encaixando esse pessoal de mais idade naquele grupo que é nosso. Nunca se formou um grupo especifico para adolescente. Sempre o acadêmico chega e fala: "nossa, mas trabalhar com 6 a 16??" Mas foi ficando. Não tem um projeto, estudo, nada não.

NO tRABALHO QUE ESTÁ SENDO DESENVOLVIDO PELOS ACADEMICOS, VOCÉ ESTÁ NOTANDO ALGUMA DIFICULDADE POR ESTAR MISTURANDO ADOLESCENTES E CRIANÇAS?

Não, sinceramente não. Porque assim, na hora do atendimento mesmo, na hora de trabalhar especificamente com ele, ai a gente já usa uma linguagem mais apropriada, né? Até o palavreado que você usa, o jeito, termos assim... Não que tenha um programa especifico pra eles. Mas na hora do atendimento individual, corpo-a-corpo, a gente já faz voltado pra ele...

NESSE TRABALHO EDUCATIVO LÁ NO AUDITÓRIO ESTÃO PRESENTES...?

As crianças, os adolescentes e os pais. Outro dia tinha um grupo de retomo, ai a gente falou pra eles: "Vamos pra lá porque você não vai ser atendido enquanto essa palestra não terminar mesmo, né?" Ai ele: "Ah, filminho de novo?" Ai eu disse: "Não, essa vai ser diferente.", então ele foi. Inclusive tinha sido uma programação diferente que os meninos (estudantes de odontologia) tinham feito, de brincadeiras, tipo uma mini-gincana e eles gostaram mais, assistiram até 0 final. Não ficaram com aquela cara assim de... Porque o adolescente, ele é assim, ele olha pra sua cara e te ridiculariza, né? Fala: "Ah meu Deus, esse povo tá achando que eu sou o quê?" Esse dia foi bom nesse sentido. 
A forma como os profissionais concebem os serviços pode determinar a continuidade ou a ruptura, criando condições para o surgimento de novas possibilidades de ação. São poucas as oportunidades dadas aos profissionais de refletirem sobre suas ações, de se informarem sobre atividades desenvolvidas por outra equipe ou mesmo outro profissional, de manifestarem suas opiniões, de trocarem idéias com colegas, de atualizarem seus conhecimentos, enfim, de mudarem as concepções que trazem sobre os serviços. Assim algumas dessas concepções se cristalizam e determinam a repetição de ações de maneira mecânica. Por outro lado, quando se encontram no próprio serviço as condições ou oportunidades para novos contatos, reflexões e experiências a postura do profissional pode ser totalmente alterada, mudando suas concepções e, portanto, a forma de agir dai por diante.

Alguns aspectos devem ser ressaltados no que concerne às concepções sobre os serviços, entre eles: necessidade de ações multidisciplinares e visão integral da saúde dos adolescentes o que inclui o envolvimento da familia ou responsáveis; os recursos humanos, desde a recepção até o atendimento final, na maior parte das vezes não têm os conhecimentos e habilidades requeridos para a atenção ao adolescente; a importância do serviço pode ser medida pela procura de atendimento, não sendo considerado o fato de que quanto mais as ações promocionais dão certo, menor são as necessidades de atendimento por parte da população; esta procura de atendimento está diretamente relacionada com a capacidade de organização do serviço e conseqüente resposta às demandas; existe uma evidente cultura de verticalização sendo esperado que os que ocupam cargos de maior hierarquia são os que devem pensar, tomar decisões e dar ordens de como proceder; a odontologia é vista como uma atividade totalmente à 
parte dos demais serviços; o tipo de trabalho que é desenvolvido na odontologia dificulta a comunicação com as demais áreas.

Profa Eleuse:

(...) Outra coisa que é muito rica é o tratamento multidisciplinar. Aoui a equipe que trabalha com adolescente é composta de enfermeiro, assistente social, psicólogo, médico e aqui neste ambulatório tem um psicopedagogo, porque aqui, há uns anos atrás, a principal queixa e o principal diagnóstico era a dificuldade escolar. E nós não tínhamos como resolver isso porque isso foge da competência da medicina e até, de certa forma, isoladamente, da educação. Então, por conta de contatos pessoais, conhecemos uma psicopedagoga, a Profa Graça, que inicialmente estava fazendo a psicopedagogia clássica, que também não estava resolvendo muito as questões. Hoje, depois de cursos no extenior com a Prof Alicia Femandes, na Argentina, ela introduziu esta metodologia, porque ela tem uma equipe grande, então é feito um diagnostico multidisciplinar com toda a familia. Ainda é um senviço incipiente porque a Profa Graça é voluntána aqui, ela é da Faculdade de Educação da UFG e só tem 20 horas e atende com uma equipe quase toda voluntánia, então vai médico, vai educadora, vai enfermeira...

COMO É QUE ESSES ADOLESCENTES SÃO TRIADOS PARA CÁ? COMO É QUE ELES CHEGAM?

Eles chegam porque primeiro é o servico mais organizado que tem em Goiânia, o NECASA é conhecido, é uma referência, então há uma procura bastante importante. Tem uma extensão no Novo Mundo e, se Deus quiser, agora no Centro de Saúde-Escola nós queremos montar um serviço lá.

Nesta fala fica explícita a diferença de postura de profissionais que têm oportunidade de conviver mais de perto com outros profissionais, particularmente com aqueles de áreas diferentes. Há também um envolvimento muito maior, uma preocupação de expansão, estendendo o serviço a outros locais, o que não é 
percebido na fala dos profissionais que estão no CAIS como, por exemplo a THD Eunice :

O SERVIÇO AQUI DO CAIS DESEMPENHA UM PAPEL IMPORTANTE PARA A POPULAÇÃO DESSA REGIÃO?

Ah, fundamental. Se não tivesse isso aqui o que seria desse povo? Você pode montar uma câmara, um obsenvatório ali fora que você vai obsenvar o contigente de gente que procura essa unidade todos os dias, é feriado, é domingo, até a noite porque aqui é uma unidade que funciona 24 horas... Dá 3 horas da manhã e aquele banco ali tá cheio de gente...

MAS ELES NÃO VISAM SO O ATENDIMENTO CURATIVO?

Pois é, o problema é esse. Porque não existe o preventivo, só existe o curativo. O que é que é feito aqui de preventivo? Ninguém faz nada.

UMA ATIVIDADE QUE ENVOLVA A OUTRA...

Não tem, ainda não está integrado...

A PROPRIA ODONTOLOGIA, ELA É TOTALMENTE DESVINCULADA DO RESTANTE DO CAIS?

Com certeza. Por exemplo, liga algum paciente aqui precisando de alguma informação ou de como conseguir uma vaga, ou que oferecemos aqui de tratamento, ninquém sabe informar. Então nossas recepcionistas que foram treinadas para isso, que fizeram curso para isso, prestaram concurso para isso, elas vêm aqui saber ou então passam uma informação totalmente errada. Chega paciente aqui querendo marcar para fazer canal porque ligou aqui e alguém mandou vir, que era só chegar aqui e fazer.

ESSA FALTA DE INTEGRAÇÃO NÃO É CULPA DOS PROPRIOS FUNCIONÁRIOS? 
Um dos fatores que eu acho, desde que eu cheguei aqui, primeiro é que a odontologia fica aqui no cantinho. Só vem aqui quem precisa de atendimento odontológico. O nosso trabalho é um trabalho que prende muito a gente aqui dentro, então você não pode ficar aqui um pouquinho, ir lá fora dar uma voltinha, conversar com o colega da outra sala, entrar na sala da enfermagem... então vocé acaba ficando isolado, acaba nem tendo amizade com os colegas e airda é taxada de chata porque não quer se misturar com o pessoal do CAIS. Mas como é que vou deixar o dentista aqui atendendo, eu auxiliando? Eu não posso largar ele aqui e dar uma voltinha, não dá. Mesma coisa o dentista, ele senta e só levanta na hora de ir embora.

NUNCA TEVE NENHUM TREINAMENTO, UMA ATIVIDADE DE INTEGRAÇÃO COM OS FUNCIONÁRIOS?

Não, houve há muito tempo, acho que em 94, não tenho muita certeza, teve um curso de relações interpessoais, mas foi coisa assim de uns 3 dias ou foi 1 dia só, nem me lembro mais direito. Nunca mais teve nada.

A THD demonstra que a importância do serviço é relacionada com o número de pacientes que o procuram. Ou seja, quanto maior o número de doentes em uma região, necessitando de atenção clínica, maior a importância do serviço. A mesma THD, logo a seguir, afirma que não há ações preventivas, o que existe se limita ao curativo e isso é afirmado em tom de reprovação, o que denota que o discurso do preventivo tem mesmo sido incorporado no cotidiano dos funcionários. Mas, não há uma relação clara entre a inexistência de atividades preventivas ou, em um sentido mais amplo, promocionais, com a demanda de serviços no CAIS.

Quanto à integração das atividades, sua fala faz notar que é algo completamente inexistente, particularmente no que se refere à odontologia. As atividades de saúde bucal, a exemplo do que ocorre na grande maioria dos serviços de saúde, são desenvolvidas totalmente à parte das demais atividades da unidade. Os usuários têm, muitas vezes, que estar presentes na unidade em 
várias ocasiões distintas para atender às exigências dos diferentes programas nos quais ele é inserido. No caso da odontologia pode ser percebido inclusive um certo rancor pelo fato das salas destinadas às atividades estarem localizadas "no cantinho" da unidade, com um isolamento que se traduz até mesmo no aspecto físico, na planta arquitetônica da unidade. Há também o fato de que as consultas odontológicas são muito mais demoradas que as médicas e exigem um tipn de intervenção "corpo a corpo" com os pacientes. Isto faz com que o tempo livre dos profissionais, enquanto presentes no CAIS, seja bastante reduzido, dificultando a interação com os demais funcionários. Esta integração também não parece estar sendo priorizada nas ações dos planejadores do serviço, uma vez que não têm ocorrido, nem sido criadas oportunidades para que esta ocorra, a não ser por determinação pessoal, por valores individuais de alguns chefes. Este fato aparece na fala do dentista Sérgio:

ATIVIDADES QUE PROPICIASSEM ESSA INTEGRAÇÃO AQUI, NUNCA TEVE NENHUMA?

Olha, às vezes os funcionánios mesmos fazem algumas festas, em chácaras, em clubes, mas isso, pelo menos eu, nunca fui. O que tem de atividade de integração é o Dr. Paulo, que é o diretor técnico, ele faz, todos os meses um almoço, uma confratemização que comemora os aniversariantes do mês. Sempre tem uma fala dele, algumas palavras, faz uma oração... Termina fazendo uma festinha uma vez por mês. Isso é uma atividade que eu acho importante, que dá pra gente socializar um pouco.

SOBRE A INTEGRAÇÃO DA ODONTOLOGIA COM OUTRAS ATIVIDADES NO CAIS? TEM ALGUMA ATIVIDADE QUE VOCESS FAZEM INTEGRADAMENTE?

Teve uma época que, se não me engano teve umas estagiánias da nutrição que usavam nossos grupos para fazer palestra também. Elas pegavam nossos grupos que estavam prontos e aproveitavam o dia pra fazer alguma palestra sobre nutrição, alguma coisa assim. Mas só. Mas as palestras eram separadas. 
E VOCE, PESSOALMENTE, SENTE ALGUMA INTEGRAÇÃO COM O PESSOAL DAQUI?

Eu venho direto pra odontologia. Os médicos que eu conheço são poucos, porque são conhecidos de outros lugares, são amigos meus de outros lugares. Tem muita gente ai que eu não conheço, não sei nem o nome.

Aqui aparece um fator que pode também influir em várias questões relacionadas às ações desenvolvidas e que é fruto direto das concepções dos profissionais. Trata-se da hierarquia na unidade. Há, dentro dos serviços, uma cultura de verticalização que começa com o status dado a cada categoria profissional e com o cargo ocupado. Esta é uma das traduções do autoritarismo que rege as ações. No exemplo, há a expectativa de que as ações de integração, quer sejam "festinhas" ou cursos planejados com este fim, devam ser assumidas por aqueles que ocupam cargos de chefia. A autoridade é conferida pela formação - nivel técnico e nivel superior -, pelo status profissional - ao médico é dado o maior status na unidade -, ou pelo cargo - as posições de direção ou chefia - e é esperada uma postura condizente por parte do profissional, o que reforça as atuações autoritárias. Mais uma vez isto é explicitado com a THD Eunice:

VOCE NÃO ACHA QUE NOS, DENTISTAS, THDS, SOMOS MUITO AUTORITÁRIOS?

Porque é assim, do ponto de vista da gente, nós achamos que o paciente está procurando tratamento aqui porque ele não tem conhecimento do que você está fazendo ali. É igual ao paciente que vai no médico, principalmente nesse espaço de saúde aqui. O que o médico disser ele vai ouvir é uma autoridade ali. É a mesma coisa o dentista aqui, o que o dentista fizer na boca está feito a não ser que dê errado, ele venha a ter um abscesso, alguma coisa, ele volta para reclamar. Mas se fez, está feito, pode colocar o que for lá que está feito. 
Năo o dentista é que sabe, ele é que faz.

No que se refere às perspectivas de expansão do serviço de atenção ao adolescente, há um interesse concreto de que este seja implantado na unidade, o que aparece em três entrevistas, da diretora da unidade - Marli, que afirma ser este um projeto já existente, da UFG e do NECASA, nas pessoas da Profa Fleuse e da Supervisora de enfermagem Maria Aparecida.

Prof $^{a}$ Eleuse:

ESSE TRABALHO QUE VOCÊS TÊM LÁ NO JARDIM NOVO MUNDO É LIGADO À SECRETARIA MUNICIPAL?

Ele é dá Secretania, mas ligado aqui, é como se fosse uma extensão nossa. No começo não era uma ligação tão forte, mas está se estreitando agora. E agora eu pessoalmente tenho um interesse especial de montar um servico no CAIS Amendoeiras.

\section{E VAI SER NESSES MESMOS MOLDES?}

Nós temos que discutir, lá vai ser bom porque nós temos a equipe multidisciplinar, por exemplo, você está lá e pode colaborar. Como lá é um grupo temos que discutir como é que vai funcionar.

Enfermeira Maria Aparecida:

VOCE TRABALHA COM ALGUM PROGRAMA DE ADOLESCENTES AQUI NO CAIS?

A gente está no desafio de implantar esse programa numa dimensão necessária, que a gente compreende que é o atendimento integral ao adolescente. Está fazendo parte das discussões nossas de políticas de atenção à criança e ao adolescente, que a gente já encaminhou tanto com o PSF [Programa de Saúde da 
Familia] quanto com a equipe da Universidade que trabalha aqui. Então a equipe está tentando implantar...

QUANDO VOCE FALA EM "EQUIPE QUE ESTA TENTANDO IMPLANTAR", VOCÉ ESTÁ INCLUINDO QUEM?

$E$ U, como enfermeira do CAIS, as pessoas da Universidade, por exemplo o Sebastião da Medicina que tem uma experiência com adolescentes no NECASA, ele $e$ a Ida, né? Nós três fazermos parte. A gente fazendo uma parceria com o NECASA, a gente já tem uma experiência acumulada no ambulatório de adolescentes do HC (Hospital das Clínicas da Universidade Federal de Goiás), né? E o PSF, na área de abrangência do PSF.

SOBRE A EXPERIÊNCIA DO NECASA NO HC, VOCÊS PENSAM EM IMPLANTAR AQUI UM PROGRAMA NOS MOLDES DO NECASA?

A proposta é mais avancada porque aqui nós temos o Programa de Saúde da Familia, que dá essa dimensão muito maior. Agora o que tem no HC que nós queriamos implantar aqui é o atendimento ao filho de mãe adolescente, fazer esse atendimento de puericultura diferenciado num ambulatório que seria de referência para uma equipe multidisciplinar, treinada para ser referéncia nesse atendimento ao adolescente. Voltada mais para o PSF.

QUE ÁREAS VOCÉS PENSAM EM DAR MAIOR ÉNFASE? QUE HÁ MAIOR NECESSIDADE?

Eu acho que dentro da visão do atendimento integral, tudo né Vánia? Das gestantes, a gente sabe que tem um número elevado de adolescentes gestantes, mas a gente não tem isso mapeado. Fazer esse atendimento de pré-natal. Fazer o atendimento desse filho, quando ele nascer. Estabelecer a parceria com a odontologia que seria fundamental estar trabalhando conosco. Agora, o que a gente precisaria? A gente precisaria da psicologia, que é uma área... nós já entramos em contato com o Lindomar [psicólogo do CAIS] que está vendo a possibilidade de a Universidade Católica transformar o CAIS em local de estágio 
do curso de Psicologia, que é como funciona no HC. Com o pessoal da Católica, com supervisão do psicólogo da unidade.

E A INCLUSÃO DA ODONTOLOGIA? COMO VOCÊ VÊ ESSE TRABALHO DA ODONTOLOGIA JUNTO AO ADOLESCENTE?

Por exemplo, eu acho que fazer um trabalho educativo de promocão e prevenção em saúde oral, né? E estar discutindo junto com a equipe. Também com a sensibilidade da visão de saúde integral do adolescente. Porque eu fico pensando que o contato do odontólogo com o adolescente é muito próximo. $\underline{A}$ partir de um problema odontológico ele pode enxergar uma série de outras coisas... Ele pode ver a saúde mental desse adolescente, como é que está a alma desse adolescente, como é que estão as relações desse adolescente, ... É um momento muito próximo com a odontologia.

A questão dos recursos humanos $(\mathrm{RH})$ foi motivo de muitas reclamaçōes por parte dos entrevistados. Esta é, na verdade, uma questão que perpassa todas as demais. São pessoas, ou seja, os recursos humanos, que realizam todas as ações. Não basta a existência de normas ou programas, por mais bem elaborados que sejam. As concepções declaradas foram as de que 0 quantitativo é insuficiente em todas as áreas e que há muitas deficiências desde a formação acadêmica até a atualização, capacitação e treinamento em serviço. Também foi abordada a necessidade de sensibilização e treinamento específico para atuação junto a adolescentes $e$, do mesmo modo, para trabalhar em uma equipe multidisciplinar. Foi abordada como uma dificuldade a distância existente entre os profissionais que atuam no nivel central e os executores das ações 
propostas. Outro aspecto levantado foi o excesso de atividades nas quais os técnicos se vêem envolvidos, não "sobrando" tempo para se criar, para se refletir sobre a prática.

De fato, não parece haver uma política de educação continuada ou mesmo qualquer forma de crescimento profissional no serviço, a não sor por iniciativas pessoais e isoladas. Esta é uma necessidade profundamente sentida pela direção do CAIS, mesmo quando questionada sobre políticas, a resposta da diretora recaia em $\mathrm{RH}$ :

E QUAL E a SUA OPINIÃO SOBRE a POLITICA DE SAÜDE DA SECRETARIA MUNICIPAL PARA O ADOLESCENTE?

É, não está sendo suficiente, né? Porque o programa não abrange todas as unidades.... Aqui na região eu só sei de um CAIS, quer dizer, de sete unidades só um. Então tá insuficiente. Não tem realmente um programa que atenda a populacão. Mas infelizmente também a gente precisa de recursos humanos, né? E uma área que é muito falha e que a gente está precisando muito é o psicólogo. Então o psicólogo é um profissional importantíssimo e nós não temos. Só temos um credenciado que vem uma vez por semana...

PENSANDO EM SAÚDE NESSE SENTIDO AMPLO, VOCÉ ACHA QUE O PRINCIPAL PROBLEMA DO ADOLESCENTE É MESMO NA ÁREA DA PSICOLOGIA?

Não é só na área da psicologia, é geral. Tem os problemas de saúde, aí tem que ter o médico, a enfermeira.... tem os dentes também, necessita do dentista. Agora aqui para nós o problema maior é o psicólogo e também o enfermeiro, que nós somos carentes e precisamos de enfermeiro em todos os programas. Há carência de recursos humanos em todas as áreas, mas eu falo do psicólogo porque ele não faz parte do quadro de recursos humanos nas unidades da Secretaria, é por isso. Os outros tem no quadro, mas o psicólogo não. Tem só 
lá no Núcleo [Núcleo de Apoio Psico-Social da SMS - NAPS que se situa na região], quer dizer tem o NECASA...só tem em locais especificos.

O próprio dentista, Sérgio, concorda com esta visão:

NA SUA OPINIÃO, ESSA ESTRUTURA AQUI DO CAIS É ADEQUADA?

Seria melhor se tivesse mais gente mais profissionais trabalhando, questão de recursos humanos. Questão de equipamentos, a gente tem, mas toda hora está em manutenção. (...)

No concernente à formação acadêmica a fala da Profa Eleuse mostra que esta é uma preocupação antiga e que ainda hoje acompanha quem lida com formação acadêmica:

A SENHORA CONHECE ALGUM PROGRAMA ESPECIFICO VOLTADO PARA SAÚDE BUCAL DO ADOLESCENTE?

Especificamente voltado para o adolescente não. Às vezes o pessoal da odontopediatria me convida para falar sobre adolescência. Acho que todas as pessoas que entram em contato com adolescente têm que conhecer um pouco da adolescência, tanto que isso faz parte do nosso curso de graduação. Nós somos a primeira faculdade do Brasil que fizemos isso, eu tive até uma luta forte por causa disso porque havia pessoas que achavam que não, porque o estudante é quase um adolescente como é que ele vai atender a adolescência. No entanto a prática mostra o seguinte: o médico sabendo ou não ele vai entrar em contato com o adolescente nas mais variadas especialidades e às vezes tem condutas que não são adequadas do ponto de vista psicológico com relação a adolescente exatamente porque ele não sabe o que é adolescência. Então nós introduzimos no curriculo no terceiro ano, na semiologia médica eles têm uma semana sobre a adolescéncia. Sobre o que é o adolescente do ponto de vista biológico, do ponto de vista psicológico, quais são as características da consulta clínica do adolescente, os aspectos éticos na prática com o adolescente e houve um tempo 
que esse curso era de uma forma muito interessante porque era vivencial, recorrendo a própria adolescência dos estudantes.

O preparo dos profissionais do serviço foi também questionado. Enfermeira Maria Aparecida:

E VOCE ACHA QUE OS PROFISSIONAIS AQUI ESTÃO CAPACITADOS A ATENDER O ADOLESCENTE DESSA FORMA QUE VOCÉ ESTÁ FALANDO?

Não. Isto é um desafio, né? Por isso que a gente fica pensando em ir por etapas. A partir daquilo que a gente já tem experiência. Então a gente ina trabalhando e capacitando estes outros profissionais. Eu entrei em conversação com o NECASA, que é da Universidade para colocar um pé aqui no centro de saúde. Tem que ver se eles têm pemas para isso...

Mais adiante ela fala do seguinte modo sobre a capacidade das pessoas de mudarem suas percepçōes $e$, consequentemente, suas atitudes e comportamentos:

\section{E VOCE ACHA QUE UM TREINAMENTO MELHORARIA ESSA RESISTENCIA?}

Ah, com certeza. Eu acredito em mudança de comportamento das pessoas, na sensibilização... O dia que a gente não acreditar nisso a gente desiste.

Ainda a mesma profissional aborda a sensibilização da equipe como o ponto fundamental para iniciar um trabalho. Fica mais uma vez explícita a importância atribuida aos $\mathrm{RH}$ e ao trabalho multiprofissional, em equipe:

SE VOCÊ FOSSE IMPLANTAR UM ATENDIMENTO AO ADOLESCENTE AQUI, QUAIS SERIAM AS SUAS PRIMEIRAS AÇÖES?

Eu acho que sensibilizar a equipe. Primeiro quem vai trabalhar com esse adolescente, o que é que esse adolescente significa para essa equipe, o que a 
gente está buscando nesse atendimento, porque trabalhar com adolescente significa trabalhar com uma equipe multiprofissional, o médico sozinho, ou a enfermeira, ou o psicólogo realmente não dá conta. Tem que ser a equipe. E a partir daí fazer o diagnóstico da saúde do adolescente dessa região, já que a gente está propondo discutir um Distrito Saudável, né?

A assistente social Lucimar expõe as dificuldades enfrentadas, tanto no que se refere à divisão do trabalho por função exercida, quanto pelas concepções que estruturam o serviço:

Eu sou assistente social do programa há três anos (...) Fizemos um trabalho em parceria com a Secretaria Municipal de Saúde e a Secretania Municipal de Educação e fizemos um trabalho muito bom com os adolescentes dentro das escolas e faltou a parte de encaminhamento especifico para saúde desses adolescentes, porque você não tem pra onde encaminhar esses adolescentes. As unidades não estão preparadas. Por mais que você treine o pessoal e os médicos, treinar não é a palavra certa, sensibilizamos os médicos para dar um atendimento diferenciado para esses adolescentes dentro da unidade de saúde. Mas é complicado porque nesse momento que a gente fez essa sensibilização eles trabalhavam com produtividade, então eles não tinham tempo para atender esses adolescentes de um modo diferenciado. Então o adolescente ficava prejudicado, porque ele chegava num pediatra e o médico falava: "Não, mas você não é mais pra mim", ele chegava num clínico geral e o médico: "Não, nessa idade sua você deve ir num pediatra", ele ficava perdido dentro de uma unidade de saúde, sem referência. Se ele vai procurar um método contraceptivo alguém diz: "Ai, mas você já está mexendo com isso? Já está usando isso?". Então, assim, a própria unidade não está preparada para receber esse adolescente pela própria concepção. (...)

Ai foi dificultando, eu sai da saúde escolar e vim exatamente para esta divisão, que é a Divisão de Saúde da Mulher, Criança e Adolescente, para estar trabalhando com adolescentes porque o Ministério preconiza que se tem que trabalhar com adolescente. Que tem todas essas nomas, toda essa programação. 
mas, do tempo que eu vim pra cá até hoje, eu não consegui fazer nada, porque você consegue fazer alguma coisa mas não é prioridade. Porque prioridade é a criança, prionidade é o desnutrido, prioridade é a mulher, prioridade é a gestante, sabe? E, se você for olhar assim, não tem como você brigar e falar...entendeu? Porque nunca sobra...olha, nem tem que discutir. (...) Então acaba que você se frustra, porque você quer fazer, mas aí a enfermeira é sobrecarregada, não tem assistente social, quando não tem assistente social é a psicóloga. Não tem uma pessoa especifica porque ela não tem tempo. (...) Quer dizer, tudo tem que ser improvisado.

Outro problema que se evidencia é a dificuldade que os profissionais lotados no nivel central têm de se aproximar das unidades. Na fala da nutricionista Maria Claudia fica explícito algo que é reclamação constante: o excesso de atividades burocráticas impede o contato com quem está atuando diretamente junto à população e são exatamente estas atividades as mais estimulantes para aqueles técnicos que pretendem transformaçōes concretas da prática.

E OS ADOLESCENTES DA VILA MAUÁ, POR EXEMPLO, TÊM BOA RECEPTIVIDADE AO PROGRAMA?

$E$, eles participam das reuniões. O pessoal está sempre vindo aqui, pegando fita de vídeo para passar para eles. Parece que eles têm... eu falo parece porque eu não tenho uma proximidade... meu serviço aqui é tanto que não dá pra eu fazer... eu fico mais no nivel central e não consigo ir numa atividade de saúde. vou esporadicamente, deveria ir mais e não consigo ir. Então eu não sei para te dizer com certeza como é a receptividade. Quando começou o treinamento dos multiplicadores, eu participei no inicio desse projeto. Foi uma receptividade ótima, na escola, eles adoraram. A gente fez e foi uma coisa excelente! Foi um trabalho que deu uma motivação muito grande pra gente porque foi muito bom o trabalho lá. 
Ainda esta mesma Chefe de Divisão, Maria Claudia, em outro momento da entrevista, ao ser questionada sobre a integração com a odontologia, aborda 0 mesmo ponto:

\section{E O PESSOAL DA ODONTOLOGIA TAMBÉM NUNCA PROCUROU} VOCÉS?

Eu acho que a questão é de falta de pessoal, que a gente não tem. A gente só toca serviço não existe aquela coisa assim, aquele momento que a gente diz vamos parar para pensar, vamos parar para integrar, vamos parar e fazer alguma coisa juntos, não tem esse momento, aqui é uma loucura de serviço. Então a gente fica só tocando esse serviço, a gente não conseque criar um pouco mais, a gente não conseque parar um pouquinho e raciocinar no que a gente está fazendo.

\section{0) RESISTÊNCIAS E DIFICULDADES}

Todos os profissionais foram questionados sobre as dificuldades encontradas e a propalada resistência ao trabalho com adolescentes e suas causas. Houve uma concordância sobre a existência desta dificuldade, mas as causas apontadas foram muito diversas. Estes problemas podem ser relacionados em dois grupos distintos: o primeiro relacionado aos próprios profissionais e ao serviço e o segundo relacionados aos adolescentes. No primeiro grupo podem ser destacados a falta de preparo do profissional para lidar com adolescentes; os tabus dos próprios profissionais, que também têm suas dificuldades como é o caso de se tratar de sexo e drogas; intolerância dos profissionais com algumas das características dos adolescentes como as brincadeiras, ridicularizações, barulho alto, linguagem cheia de gírias e outras; as consultas com adolescentes 
acabam demandando um maior tempo por haver a necessidade de explicação com clareza de cada ato e os profissionais têm um número de atendimentos a ser realizado, isso pode atrasar a agenda; necessidade de criação de vínculo afetivo ou emocional com os adolescentes para se atingir os objetivos educativos estabelecidos e necessidade de envolvimento da família, dificultando o processo.

No segundo grupo, ou seja, aquele relacionado aos próprios adolescentes, foram apontadas como dificuldades algumas características destes como o fato de ser crítico e contestador. Também foi abordada a alta complexidade dos problemas que envolvem o adolescente como as drogas, a sexualidade e os relacionamentos familiares e interpessoais.

Um aspecto a ser ressaltado é o de que, nas falas, tudo indica que nenhum dos profissionais tenha dificuldade de trabalhar com adolescentes. Ao contrário, afimam que, comparando com crianças, estes são melhores de se trabalhar. Existe evidentemente 0 viés de estes profissionais terem sido escolhidos para participar desta pesquisa justamente por estarem ligados de alguma forma a ações que envolvem adolescentes. Mesmo assim pode-se afimar que isto não deixa de ser surpreendente se for considerado o número reduzido de ações desenvolvidas para este grupo populacional.

Nutricionista Maria Claudia:

QUAL E A GRANDE DIFICULDADE QUE OS PROFISSIONAIS TEM QUE NÃO GOSTAM DE TRABALHAR COM ADOLESCENTES?

Porque o adolescente é crítico, te lembra da sua adolescéncia te lembra da sua sexualidade, então tem todo um ... que mexe com o profissional. Uma questão pessoal e por falta de preparo também. $O$ adolescente critica, ele te pega no ponto fraco, ele é, como a criança, sensivel, ele sabe quem gosta, que está fazendo aquilo porque gosta e quem está por obrigação. $O$ adolescente não é mais criança que você fala com a mãe e a mãe faz. você tem que falar com ele, você tem que 
convencer ele. Porque a mãe não vai escovar os dentes de um adolescente... Todo mundo sabe das dificuldades que isso cria.

\section{MAS OS PROFISSIONAIS TEMM MUITA RESISTENNCIA?}

Têm muita resistência... Nossa! Na área médica, na área de enfermagem, tem muita resistência porque você vai tratar de questões da sexualidade e tratar disso "é um horror".

VOCÉ ACHA QUE O QUE PEGA TAMBÉM É O TABU QUE OS PROPRIOS FUNCIONARIOS TEM?

Talvez o lembrar que você não é mais um adolescente, da inveja mesmo embutida que as pessoas têm, sei lá, eu acho que é um misto assim de tudo que dificulta esse atendimento. As pessoas têm pouca tolerância a essas questões, por exemplo, o brincar do adolescente, ficar rindo a toa... parece que pularam essa fase, né? Esqueceram, não lembram que faziam isso. Aqueles adultos jovens, engraçado, são os mais resistentes. Ele ainda está com um pé lá na adolescência, mas ele renega. Talvez por imaturidade... Há negação talvez.

A Diretora da Unidade, Marli, fala da sua dificuldade em encontrar alguém para atuar junto a adolescentes e ressalta a necessidade de se fazer trabalhos sempre envolvendo a família o que, em sua opinião é um complicador. Um outro aspecto a ser destacado na sua fala e relacionado com a estruturação dos serviços é o do vínculo a ser criado e o tempo gasto com isso.

DE MODO GERAL A GENTE VE MUITA RESISTÉNCIA DE FUNCIONÁRIOS, PRINCIPALMENTE NESSE ASPECTO EDUCATIVO, DE TRABALHAR COM ADOLESCENTES, PREFEREM CRIANÇAS, QUE É MAIS FÁCIL ...

$E$, realmente. Aqui mesmo eu estava procurando um médico para..., um pediatra, para atender adolescentes e realmente eu estou achando complicado encontrar. 
E PORQUE VOCÉ ACHA QUE SE TEM ESSA NOÇÃO DE QUE É DIFICIL TRABALHAR COM ADOLESCENTES?

Não sei. Pode ser pela questão dos problemas de estar envolvendo a familia que tem que estar acompanhando não só o adolescente, mas tem que estar conversando com a familia também, por ele ser menor de idade. Como se diz, é todo um ciclo porque o adolescente precisa realmente de atenção.

VOCÉ ACHA ENTÃO QUE É POR ISSO, PORQUE TEM QUE ENVOLVER TAMBÉM A FAMILIA?

E. A consulta também é mais demorada, você vai ter que ficar mais tempo com ele, você vai ter que estabelecer vínculo.

VOCÉ FALA VINCULO AFETIVO?

$E$, um vínculo afetivo porque se o adolescente não confia no profissional ele não vai se abrir, ele não vai conversar o que realmente está precisando.

Esta percepção é também compartilhada por Maria Aparecida:

DEIXA EU TE PERGUNTAR UMA COISA, DE MODO GERAL, E ISSO É UMA PERCEPÇÃO MINHA, EU VEJO QUE OS FUNCIONÁRIOS SÃO RESISTENTES A TRABALHAR COM ADOLESCENTES. VOCE PERCEBE TAMBÉM ESSA RESISTENNCIA, OU NÃO?

Essa resistência a gente enfrenta ela com os funcionánios, com os estudantes das diversas áreas que lidam aqui, por exemplo, da medicina, da enfermagem... Por que? Porque o adolescente que chega pra gente, às vezes, vem um adolescente com um grau de complexidade de vida. Às vezes você recebe usuário de droga, então exige essa disponibilidade inclusive afetiva, do acolher, e as pessoas, às vezes, não estão dispostas a isso. 
Já para a dentista Maria Fernanda, as maiores dificuldades estão nas atividades educativas, então, ao ser questionada especificamente sobre isto, veio a tona, mais uma vez, a questão do despreparo para o atendimento:

E VOCE VE NOS ESTUDANTES, DENTISTAS OU FUNCIONÁRIOS QUE FAZEM A PARTE EDUCATIVA, ALGUMA DIFICULDADE DE TRABALHAR COM O ADOLESCENTE?

É porque normalmente é assim, o acadêmico que gosta de trabalhar com palestra, com prevenção, eles já estão voltados para odontopediatria. Ele já quer usar o fantoche, quer cantar a musiquinha, quer ensinar uma estorinha que fala de dentinho, bichinho da cárie... Então quem gosta está mais voltado para esta área. Ele não está preparado para falar para o adolescente, realmente. Aquele que não gosta, que acha chato essa parte, acha chato pra crianca, adolescente, todo mundo. Então eu acho que realmente é uma deficiência mesmo. É complicado, porque você vai falar pra ele do bichinho da cárie? Ele se sente menosprezado, ele não está mais ouvindo aquilo.

Fica também registrada a dicotomia presente desde a formação acadêmica e que se estende ao longo de toda a vida profissional, entre atividades educativas/preventivas e curativas. O profissional que atua como dentista em unidades de saúde, usualmente não difere o que é realizado na boca de seus pacientes pelas características das pessoas e sim pelas características do trabalho executado - dentística, cirurgia, endodontia etc. Isso normalmente só é levado em consideração durante as atividades educativas. Talvez por isso as atividades de educação sejam, quase sempre delegadas às auxiliares ou, no caso desta unidade, aos estagiários. A postura dos profissionais costuma ser a de preferir aquele paciente que Ihe dá "menos trabalho", também em função das exigências quantitativas do atendimento. $O$ exposto está plenamente acorde com as falas dos demais profissionais aqui entrevistados.

Dentista Sérgio: 
E VOCE TEM UM NÚMERO DE PACIENTES NO CURATIVO...

Tem, tem. Pelo que eles pedem tem que fazer 3 pacientes completos por dia. É um pouco difícil, né? Mas a orientação é essa.

\author{
OS ADOLESCENTES APRESENTAM ALGUM TIPO DE PATOLOGIA \\ MAIS FREQUENTE? \\ O mais freqüente, lógico, é a cárie...
}

\title{
ALGUMA QUEIXA ESPECIFICA OU ELE NÃO SABE NEM O QUE TEM NA BOCA?
}

Ele não sabe nem o que tem na boca. Às vezes eu falo: "Tudo Bom?" e ele "Tudo bom." E é só isso que conversa. Normalmente não tem queixa. Às vezes ele fala: "Ah, meu dente tá doendo." E eu falo que já vou por um curativo nele, esse dente vai ter que fazer canal, mas é só isso. Queixa de dor, às vezes tem queixa de mau cheiro...

VOCE SENTE RESISTENCIA POR PARTE DOS FUNCIONÁRIOS (THDS, DENTISTAS) EM ATENDER O ADOLESCENTE?

$E u$, pessoalmente, não gosto muito da parte de pediatria. Então quando $o$ menino é muito pequenininho eu tenho uma certa aversão. Prefiro atender adolescentes do que crianças mesmo. E as THDs que trabalham comigo, também. Tem a odontopediatra, Dra. Lilian, que fica com as crianças.

\section{VOCE SE SENTE PREPARADO PARA ATENDER O ADOLESCENTE?}

Eu prefiro o adolescente. Eu me sinto melhor preparado do que para atender criança.

INCLUSIVE NAS ATIVIDADES EDUCATIVAS TAMBÉM?

... (longa pausa)... Olha, eu nunca tinha pensado nisso... de repente... porque 6 a 16 é uma faixa etána, é uma amplitude muito grande.... Lógico que 
quando eu estou falando para os mais pequenininhos, eu dinjo mais pra eles. Quando estou tratando com os de idade mais avançada, ai eu falo com outras palavras... Mas, ... eu acho que... indiferente... mas se for para escolher entre adolescente e criança eu prefiro adolescente.

A THD Eunice, que atua neste CAIS há oito anos, expressa a razãu pela qual há uma dificuldade de atuar em atividades educativas com adolescentes:

VOCE, PARTICULARMENTE, TEM ALGUMA RESISTENCIA PARA TRABALHAR COM ADOLESCENTES? ATIVIDADES EDUCATIVAS...?

Ih... tenho a maior... Até gosto mais de lidar com adolescente do que com criança pequena e com adulto. Eu tenho mais resistência com o adulto do que com a criança e o adolescente.

SE FOSSE CRIADO UM PROGRAMA DE ATENDIMENTO AO ADOLESCENTE, VOCE SE CANDIDATARIA PARA TRABALHAR?

Com certeza. Eu acho bem mais interessante.

MAS TODO MUNDO RECLAMA QUE ATIVIDADE EDUCATIVA COM ADOLESCENTE E MUITO MAIS TRABALHOSA...

Lógico, né? Porque o adolescente é bem mais dinâmico, então ele não é mais como a criança que você diz: "Senta ai que a Tia vai mostrar um filminho para você..." e você tem a atenção dele com isso. Para o adolescente você precisa estar sempre elaborando coisas novas. Eu acho que uma coisa boa para estar trabalhando com ao adolescente é pensar na dinâmica mesmo, uma coisa mais movimentada, que tenha mais movimento, que seja mais interessante para ele.

QUE ELE PARTICIPE MAIS...

Lógico, né?, Porque ele não vai ficar lá, uma hora, sentado, vendo filminho de como cuidar dos dentes... 
VOCÉ JÁ FEZ ALGUMA ATIVIDADE EDUCATIVA ESPECIFICA, SO PARA ADOLESCENTES?

Já na escola. Eu trabalhei na $4^{a}$ série com adolescente. Nossa, me dei muito bem. Trabalhei 2 anos com a $4^{a}$ série. Já havia trabalhado 5 anos com criança pequena, nesses 2 anos foi ótimo trabalhar só com adolescente... é mais dinâmico, minhas aulas eram uma zona total.

VOCE DISSE QUE GOSTA DE TRABALHAR COM ADOLESCENTE, MAS VOCE ACHA QUE É UM SENTIMENTO COMUM DE THDS E DENTISTAS?

$A h$, com certeza não é a maioria não gosta porque o adolescente contesta muito. Se você está fazendo alguma coisa na boca dele ele quer saber o que você está fazendo, porque você está fazendo aquilo, como é que isso vai ficar... e a criança não, no máximo ela pode ter é medo e ficar mais resistente. Mas o adolescente não, ele é muito curioso quer saber que massinha é aquela ali, porque você está usando essa luva, porque você pegou aquilo ali.. ai essa parte é chato, né? Vocé está trabalhando e a pessoa investigando tudo... não é todo mundo...

No final desta fala surge um outro elemento de análise: o desconforto de ter pessoas verificando e questionando as ações realizadas. Este desconforto parece ser mais exacerbado naqueles profissionais que não se sentem totalmente seguros de suas ações. 


\section{$\left.6^{\circ}\right)$ POSSIBILIDADES DE ATUAÇÃO JUNTO AOS ADOLESCENTES}

Tanto sob a forma de um programa de atenção integral ao adolescente ou como ações isoladas específicas da odontologia, ficou clara a possibilidade de desenvolver ações voltadas exclusivamente para o adolescente. Mais que isso, essa parece ser uma intenção bastante sólida dos profissionais que atuam no planejamento das ações. Para os dentistas e THD isso já é uma realidade. Estes desenvolvem ações com os adolescentes mesmo sem terem tido nenhum tipo de preparo para tal. Os adolescentes foram se integrando ao grupo de usuários por diferentes motivos, dos quais os profissionais envolvidos não tomaram conhecimento, mas já estão muito presentes nas ações da odontologia. Basta que se veja o grande número deles nas listas de atividades. As possibilidades de atuação estão condicionadas à criação de um grupo de adolescentes, a exemplo do que já ocorre com outros grupos populacionais, ao envolvimento de um maior número de profissionais de diferentes áreas, à integração da odontologia com as demais áreas para o desenvolvimento de ações conjuntas e à destinação de tempo para o planejamento destas atividades.

Maria Fernanda relata como a integração dos adolescentes ao seu trabalho aconteceu para ela:

NESSA ATIVIDADE SE TIVER CRIANÇA DE 6 E ADOLESCENTE DE 16 ELES FICAM TODOS JUNTOS?

(...) Na verdade era de 6 a 12, depois passou pra 6 a 14, ai colocou pra 6 a 16. Mas sempre encaixando esse pessoal de mais idade naquele grupo que é nosso. Nunca se formou um grupo especifico para adolescente. Sempre o acadêmico chega e fala: "nossa, mas trabalhar com 6 a 16??" Mas foi ficando. Não tem um projeto, estudo, nada não. 
TEM CONDIÇÃO DE DESENVOLVER UM PROGRAMA ESPECÍFICO PARA ADOLESCENTES AQUI NO CAIS?

$E$, eu acho que tem. Mas eu mesma me sinto deficiente nesse ponto. Acho que quando eu vou lidar com o adolescente na cadeira é diferente. Eu consigo conversar com ele, me coloco de igual pra igual, deixo ele participar, falar alyuma coisa, mas a parte educativa com o grupo, realmente eu tenho dificuldade. Porque é difícil de motivar, tem que ter alguma coisa que seja do interesse deles e eu não aprendi ainda o jeito.

VOCE, ANALISANDO A ODONTOLOGIA COMO UM TODO, ACHA QUE ESTAMOS PREPARADOS PARA LIDAR COM O ADOLESCENTE?

Sinceramente eu nunca parei pra pensar nisso. A gente sempre colocou isso: tem o odontopediatra que gosta de tratar da criança, ai tem o outro que quer tratar do adulto dos 18 pra frente, dos 12 aos 18 fica meio assim... Mas eu nunca parei pra pensar se é uma resistência , uma questão mais nossa. A gente vai convivendo com isso sem muito questionamento. $A$ gente vai fazendo, eles vão mandando e a gente vai fazendo... Quando eu entrei na prefeitura me falaram que eu ia trabalhar com esse grupo de 6 a 16 anos, bem heterogêneo. Eu até cheguei a questionar se ia ter uma divisão...

QUE TIPO DE TRABALHO, ATIVIDADES, VOCE ACHA QUE É ADEQUADO PARA ESSE TRABALHO EDUCATIVO EM SAÚDE COM O ADOLESCENTE?

Eu acho que principalmente uma coisa que tenha grande participação dele, que ele possa estar fazendo junto, talvez envolvendo atividade manual, alguma coisa assim. Também essa parte de competição e voltado pro lado da estética, da conquista.

DA FORMA QUE O SERVIÇO ESTÁ ESTRUTURADO, DÁ PARA ATENDER AO ADOLESCENTE? 
Eu acho que aqui tem um espaço privilegiado. Do jeito que está, dá pra atender, agora pode melhorar. Pode servir de modelo para outros lugares. Pelo fato de aqui ter um espaço físico bom, de ter um auditónio, tem como melhorar isso ai. Mas tem que ter o envolvimento de muita gente. Ter muita gente querendo fazer porque acho que tem que sentar, estudar um jeito. Não tem grupo de adolescente neste CAIS. Eu acho isso uma deficiência, porque tem grupc de hipertenso, de gestante de idosos, então tá faltando...

VOCE ACHA QUE O ADOLESCENTE SAI SATISFEITO COM O TIPO DE TRABALHO, COM A ATENÇÃO QUE ELE RECEBE AQUI?

Eu não acho que ele saia muito satisfeito não. Ele sai tipo missão cumprida: "fui lá, olhou meu dente e pronto."

Esta fala mostra que as possibilidades de atuação junto aos adolescentes do CAIS são concretas, inclusive no aspecto físico da unidade. A própria dentista demonstra ter conhecimento do tipo de atividade mais adequada nesse caso, embora ela alegue não ter pensado muito a respeito. É também reconhecido que o que é realizado não é o ideal nem para os profissionais que se sentem com uma certa frustração por se manterem na rotina do atendimento, nem para os adolescentes que saem da unidade apenas com a sensação de "missão cumprida". A dentista levanta ainda um outro ponto a ser pensado, a falta de planejamento, estudos, avaliação. Ponto também explicitado na fala da Profa Eleuse:

VOCÉS TEMM TRABALHADO COM O GRAU DE SATISFAÇÃO DO ADOLESCENTE COM RELAÇÃO AO TRABALHO?

Nós não temos e, aliás, isso é muito interessante, é um dos grandes problemas dos serviços brasileiros. Eles são planejados por uma necessidade. A gente começa sem planejar uma forma de avaliar. 
E ela continua falando que "No treinamento da Faculdade de Medicina não está incluida a saúde bucal, (...) Os assuntos predominantes são: sexualidade e drogadição. (...) É interessante porque, por exemplo, eu sou cliente da Enilza [Profa de periodontia da Faculdade de Odontologia da UFG] e eu não sabia que tinha doença periodontal em adolescente e é a tese dela."

Mais uma vez surge o fato de que as áreas da saúde têm a característica de trabalhar completamente separadas. Mesmo uma profissional com competência reconhecida na área e com a experiência da Profa Eleuse desconhecia um fato básico para quem lida com saúde bucal do adolescente que é a existência de doenças periodontais. No entanto isso não pode ser atribuído à profissional e sim à forma fragmentada com que a saúde é vista. Também aparece o problema do planejamento e avaliação das ações. Na entrevista de Maria Claudia surge novamente $o$ isolamento da odontologia, mas fica clara a possibilidade de ações conjuntas:

GOSTARIA DE SABER SE AQUI NA SUA DIVISÃO TEM ALGUM TRABALHO QUE TRATE DA SAÚDE BUCAL DO ADOLESCENTE, SE VOCÉS ABORDAM ESSAS QUESTÓES OU NÃO?

No início, quando a gente começou a querer implantar o programa da saúde do adolescente nas unidades de saúde, porque o Ministénio da Saúde prevê a assistência de saúde bucal, a gente tentou fazer essa anticulação do atendimento ao adolescente de modo integral, então olhando também a questão da saúde bucal. Só que a gente teve muitos empecilhos, a questão que já existe uma idade prionitária, que iá existe uma coisa articulada na odontologia, então ninguém nunca conseguiu isso. Esse empecilho na odontologia que não prevê o adolescente como um todo, a extensão à adolescência. Ele prevê o adolescente na idade escolar que se considera até quatorze anos. Então sempre ficou esse buraco aí, acima de quatorze anos a gente não tem uma assistência, pelo menos não prevê uma assistência e aqui na Secretaria Municipal a gente não tem ainda esse costume de estar trabalhando integrado, nos programas eu não tenho visto 
esta integração (com odontologia, com saúde da familia)...eu não tenho visto esta integração, pelo menos com odontologia não. A odontologia é um programa enorme, a questão da saúde bucal que trabalha mais ou menos à parte. Eu vejo assim, acho que não tem muita integração com outros...

COMO É FAZER INTEGRAÇÃO COM A ODONTOLOGIA? É POSSÍVEL A INTEGRAÇÃO COM A ODONTOLOGIA NAS UNIDADES?

Aqui, na verdade essa integração talvez não tenha acontecido porque o senviço não aconteceu. Eu acredito assim que à medida que a gente estrutura um servico, que a gente comeca a funcionar direitinho, a gente vai fazendo que ele funcione como um todo e vai integrar a unidade toda todos os serviços da unidade. Então, o que está acontecendo é que, na verdade, não tem mesmo nenhum atendimento bonitinho do adolescente. Em nenhuma Unidade da Secretaria existe esse atendimento nos moldes que a gente gostaria que tivesse.

QUE TIPO DE ATIVIDADE VOCE ACHA QUE A ODONTOLOGIA PODERIA ESTAR DESENVOLVENDO JUNTO AOS ADOLESCENTES?

Eu acho que a prevençăo. A prevençåo, assim, adaptada para o adolescente. Não aquela coisa de ficar dando palestrinha com aquelas figuras infantis, sabe? Eu acho que a prevenção voltada para a questão da beleza, daquela coisa que o adolescente gosta, valorizando a questão da auto-imagem. Bem própria para o adolescente. Programas educativos de prevenção da questáo de problemas da saúde bucal, de valonizar isso, mas de uma forma adequada para o adolescente. Eu não sei bem, talvez até tenha e eu não conheça. Mas eu sinto que isso é bastante importante e estar integrado com o grupo, porque quem trabalha com o adolescente tem que ter uma formaçáo para trabalhar com o adolescente. Tem que entender um pouco de adolescência. Não falar a fala dele, por que ele também não quer nenhum adulto bobão falando como adolescente. Mas falar de uma maneira que atinja o adolescente. Então, tem que ser um profissional treinado para isso. Não ficar com coisinhas de usar bonequinhos de crianças, que eles não gostam disso, mas também não ter uma fala de adulto. $E$ 
uma coisa no meio do caminho mesmo, próprio para adolescente. Eu acho assim, valonizar muito a questão da auto-imagem, eles valorizam isso, a questão da beleza. Toda vez que eu atendo adolescentes, eu falo pra eles: "Tem que conservar os dentes, sai da mesa: escova os dentes." Porque a alimentação tem muito a ver. Eu sempre estou falando isso, mas reforçando isso assim, "olha os dentes, você tem os dentes bonitos, esses aí são os últimos, não tem uma terreira dentição."

MAS A COISA QUE VOCÉ ACHA QUE PEGA NA ADOLESCENNCIA É ESSA COISA DE VAIDADE MESMO, DE APARÉNCIA. NÃO ADIANTA VIR COM CONVERSA DE FUNÇÃO DE DENTE E TAL?

$\dot{E}$, talvez entender um pouco da denticão, acho que é interessante também e eles gostam muito disso. É uma época que você esta deixando do concreto e está abstraindo. Então ele consegue abstrair, não é igual uma criança que vocé precisa estar explicando assim com muito... eu acho que talvez seja uma coisa interessante ele estar entendendo isso.

VOCÉ VÉ ALGUMA POSSIBILIDADE DE DESENVOLVER UM TRABALHO CONJUNTO DESSA DIVISÃO COM O DEPARTAMENTO DE ODONTOLOGIA VOLTADO PARA O ADOLESCENTE?

Ah, eu vejo. Tem que ter o espaço da odontologia nessas reuniões...Eu não tenho tido tempo para pensar... mas o pessoal da odontologia é bem aberto e nós também somos muito abertos. A gente não tem dificuldade de relacionamento, nada, isso é importante, né? Eu não vejo resistência. Eu acho que falta mesmo é tempo, falta gente, ter gente suficiente para essas coisas: "vamos inventar agora. Vamos largar disso aqui e resolver o que está lá, vamos criar um pouco...", esse tempo, não tem. Talvez todo grupo que for começar agora voltado para o adolescente, já chamar o pessoal da odontologia que tiver disponibilidade pra começar a insenir isso... 
Para a assistente social Lucimar os adolescentes estão sim preocupados com a boca, mesmo que por questões de estética, então existem possibilidades de atuação, só que estas não estão tão diretamente relacionadas à estruturação do serviço quanto estão com as pessoas executoras. Novamente a responsabilidade recai nos profissionais:

NO NOSSO CASO, QUE TRABALHAMOS COM SAÚDE BUCAL, ISSO NÃO É PREOCUPAÇÃO DELES...

Mas é. Porque o adolescente preocupa muito com a aparência dele. Você pode observar que o adolescente quer ver o cabelo bonito, o somiso bonito, entendeu? A roupa, o corpo, ele quer fazer musculação... então ele preocupa, eu acho que ele preocupa. Por isso até quando a gente foi fazer essa cartilhinha a gente pensou nisso, entendeu? Porque ele não tem cuidado com a alimentação, ele come muita coisa mas se você vai falar porque ele está ficando obeso, está muito magro ele preocupa porque a preocupação dele na adolescência é a aparência só isso. Então a saúde bucal eu considero muito importante, assim, não só a saúde bucal como as outras, exatamente por isso, porque ele está preocupado com isso.

MAS ENTÃO ELE ESTÁ PREOCUPADO COM A SAÚDE BUCAL PELA ESTÉTICA E NÃO PELA FUNCIONALIDADE?

Não, não, năo, o negócio deles é estética e tal. Você tem que falar pra eles o quê que é bom para os dentes, que os dentes vão ficar bonitos, vão ficar branquinhos e tal. É por aí que pega, eles se preocupam demais com isso. Eu até estou vivenciando isso em casa, o meu menino só pensa no cabelo, passa a mão no cabelo o dia inteiro, penteando...Ainda bem que ele está gostando, achando lindo. Porque existem aqueles que não gostam do cabelo, não gostam da pele. Há rejeição total com ele mesmo.

A ESTRUTURA DO SERVIÇO ESTÁ ADEQUADA? DÁ PARA TRABALHAR COM ADOLESCENTES? 
Eu acho que não está estruturado para atender nada, quanto mais adolescentes. Mas, eu penso o seguinte, tudo o que você quiser fazer, você faz. Tem relato de grupo que trabalhava debaixo de uma árvore. Vai muito da vontade, porque quando o profissional gosta, ele gosta mesmo, ele se identifica, ele quer trabalhar, né? Tem umas estruturas otimas, igual às do CIAMS [unidades maiores da SMS], que tem isso, tem aquilo. Mas, às vezes, o profissional que esté lá dentro não tem interesse. Às vezes, tem um profissional que está numa unidade desse tamaninho, que não tem nem sala de reunião, mas ele gosta, então ele dá um jeito, faz aquilo achando bom. Impossivel não é. Acho que tem que falar mais do adolescente. Estáo começando a falar, na mídia, na TV, do adolescente, entrevista, é isso, é aquilo... então está começando.

Maria Aparecida recorda do atendimento ao bebê da mãe adolescente como uma possibilidade concreta, mas o vê como uma parceria, não dentro de um programa de ações integradas:

E VOCE JÁ PERCEBEU ALGUMA NECESSIDADE DE ODONTOLOGIA DOS ADOLESCENTES COM OS QUAIS VOCE TRABALHA?

$A h$, com certeza. Por exemplo, os filhos da mãe adolescente, quando a gente discute saúde oral, ela já sabe inclusive do programa do bebê. Isso seria uma parceria fundamental pra gente.

DE MODO GERAL ELES FICAM SATISFEITOS COM O TIPO DE ATENDIMENTO QUE ELES RECEBEM AQUI?

Ficam, de modo geral ficam. Eles procuram mais a assistência curativa, né Vânia? Eles procuram o médico, o remédio, o anti-concepcional... às vezes a odontologia também, a questão reparadora só. A parte de prevenção, de promoção ainda precisa de se fazer. 
A THD Eunice demonstra conhecer bem a realidade da região e do adolescente. Ela vê atividades com adolescentes como uma forma de suprir necessidades que não são respondidas em outros locais ou espaços sociais:

VOCE ACHA QUE O ADOLESCENTE É, DE MODO GERAL, RECEPTIVO A TRABALHOS EDUCATIVOS COMO ESSES QUE VOCE JÁ VIII E DESENVOLVEU?

Ele é receptivo. O problema do adolescente é que ele contesta um pouco, mas na verdade ele quer aquilo. Só que ele quer saber o porquê. Ele só não aceita assim tudo que vier ele vai engolir, ele não engole. Ele quer saber. Mas se você também tiver jeito para trabalhar com adolescente e se souber levar, ele é a melhor pessoa para se lidar. Porque, de certa forma, ele já tem um raciocínio bem mais avançado, ele aprende com mais facilidade. Se você tiver paciência, tiver um jeito, porque se for bancar a durona e for fazer isso, ele não vai fazer. Se você deixar ele solto, "faça o que quiser", ele também vai ficar na dele e não vai querer, então você tem que conquistar. Ele tem que ser conduzido, mas não imposto. E vocé também tem que ter uma certa amizade com ele para ele perceber que você está do lado dele, não é alguém que está ali só querendo mandar ele fazer isso, fazer aquilo, mas que você está interessada no bemestar dele também.

SERIA POSSIVEL DESENVOLVER UMA ATIVIDADE AQUI NO CAIS VOLTADA SO PARA O ADOLESCENTE?

Eu acho fundamental, essa comunidade é tão carente disso... eu acho que é possivel sim. Existem tantos programas aí, para diabéticos, obesos, para tanta coisa, porque para ele não? Pro adolescente que está numa fase tão perigosa, principalmente aqui, os adolescentes acabam se envolvendo com drogas muito cedo, principalmente por isso, por falta de ter com quem conversar, sobre o que conversar. O pai e a mãe saem cedo para o trabalho e ele fica na rua, às vezes vai para o Colégio. No Colégio "entuma". Chegando em casa ele mesmo faz a comida dele ou esquenta a que a mãe deixou de ontem da janta e fica solto. $A$ mãe chega e não dá conversa pro filho porque já chega cansada e tem que fazer 
a janta, tem que cuidar da casa... Então ele vai ficar angustiado, com quem ele vai dividir as angústias dele? Não tem um psicólogo, não tem ninguém para apoiar ele não. Às vezes a professora não está nem preocupada com isso também, quer só passar o conteúdo dela lá no quadro e não está nem preocupada com o que o aluno tem ou não tem. 


\section{2 - OS ADOLESCENTES DO CAIS}

\section{9) CARACTERIZAÇÃO DOS ADOLESCENTES}

Nesse item o que se buscou foi caracterizar os adolescentes a partir de suas próprias falas. A observação mostrou que há um número grande de adolescentes que procuram o CAIS para atendimento odontológico e estes formaram o público alvo desta pesquisa. É, portanto, muito provável que os entrevistados não se constituam em exemplos típicos dos adolescentes, pelo menos no que se refere aos cuidados dispensados à saúde bucal. Todos tiveram que enfrentar no mínimo um grande obstáculo para estarem ali que foi a fila de espera, o que certamente não é visto como algo fácil. Todos estavam no CAIS no período diurno e este é um dado a ser ressaltado, já que apenas uma das adolescentes entrevistadas não era estudante, tendo abandonado os estudos para trabalhar, segundo sua informação. As idades dos entrevistados variaram de 12 a 17 anos, não tendo sido incluídos jovens de mais idade porque estes não são atendidos no serviço odontológico da unidade. O período de tempo que passam no banco a espera de serem atendidos é considerado longo demais, porém é usado como uma forma de socialização. Pode-se observar que muitos deles ficam conversando e parecem já conhecer uns aos outros há algum tempo. Não é 
possivel determinar se este conhecimento se deve a contatos por morarem na mesma região, freqüentarem as mesmas escolas ou se o conhecimento foi travado na própria unidade. Entre os entrevistados havia dois que moravam em uma cidade vizinha, Bonfinópolis, distante cerca de $30 \mathrm{~km}$. Esta absorção de pacientes de outra cidade foi relatada como algo bastante comum pelos funcionários daquele CAIS, pois não existe atendimento naquela cidade. Todos os adolescentes relataram que a região é muito carente de opções de lazer, então se divertem, em sua maioria com os amigos. Foram referidas por vários adolescentes a música e a TV como atividade de lazer. A preocupação com a imagem perante os demais surgiu em várias falas. Os adolescentes entrevistados mostraram-se com muitas responsabilidades, sendo que estas não se limitam às atividades escolares, mas também estendem-se ao trabalho e aos cuidados com a própria casa. Também pode ser percebida a importância da escola e da igreja na vida destes jovens, tanto na construção de seus valores quanto como um local de socialização. Um exemplo é a fala de E 16:

QUANDO VOCÉ NÃO ESTÁ ESTUDANDO OU TRABALHANDO, O QUE VOCE FAZ DE LAZER, PARA DIVERTIR?

Fora trabalhar? Ah, eu vou para a igreja, porque eu sou evangélica.

ALEM DA IGREJA? AMIGOS, VISITAS?

Visitas muito não, nem amigos. De vez em quando eu escuto música...

VOCE DISSE QUE AQUI NÃO TEM MUITA OPÇÃO DE LAZER, DE DIVERSÃO PARA OS ADOLESCENTES. ENTÃO A ÚNICA COISA MESMO QUE ELE TEM PRA FAZER É FICAR COM OS AMIGOS CONVERSANDO?

Ah, como eu disse eu vou na igreja, e lá a gente convive com os obreiros, com os meninos da igreja. Lá eu não tenho assim... eu gosto muito de ficar lá com eles, eles ensinam a gente como é que a gente deve ficar. Por isso que eu disse pra você que eu não saio, não tenho amigos, não tenho visitas assim muito. $A$ gente convive na igreja ou então em casa mesmo, com a mãe da gente 
ensinando. Porque lá em casa a gente não tem nada que reclamar da nossa mãe ela ensina muito a gente.

A fala de L 15 retrata bem o que foi relatado por quase todos os adolescentes com relação a seu tempo de lazer:

QUANDO VOCÉ NÃO ESTÁ NA ESCOLA, O QUE VOCÉ FAZ PARA SE DIVERTIR? OS JOVENS DE MODO GERAL AQUI DA REGIÃO, O QUE ELES FAZEM?

Saem.

PRA ONDE?

Não tem lugar não, assim, por exemplo, na feira, dia de quarta-feira tem feira a noite, nós vamos pra lá... de sábado...

SEI, MAS AQUI NA REGIÃO MESMO, ALGUM LUGAR QUE TEM ESPORTE...?

Não, não tem. Não tem nada pra fazer. Eu faço aula de dança, mas é por minha conta.

E QUANDO VOCE NÃO SAI? EM CASA, O QUE É QUE VOCÊ FAZ? Video-game, música...

DE MODO GERAL É ISSO QUE SEUS AMIGOS FAZEM?

$E$, é isso...

A fala de $M 12$ é muito semelhante:

O QUE É QUE OS ADOLESCENTES FAZEM AQUI PARA SE DISTRAIR, $D E L A Z E R ?$ 
Huuuuuum... tem a rua de Cooper que é muito bom. Lá é bom porque tem muita gente, você faz muito amigo, é bom. Fica todo mundo lá andando...

\section{TEM BAR LA, ALGUMA COISA?}

Tem não.

O QUE MAIS VOCE FAZ?

Eu?? (risos) saio.

\section{PRA ONDE?}

Pra casa da minha tia, vánios lugares.... com meus amigos eu não saio porque meu pai não deixa. Ele fala que eu sou ainda muito nova, né? Agora quando eu quero, eu saio com minha irmã, pra feininha dia de sexta e sábado...

\section{QUE É QUE TEM LÁ?}

Tem muitas coisas pra você olhar, tem um barzinho lá que passa muita música lá, então é bom também.

\section{E QUANDO VOCÉ ESTÁ EM CASA?}

Eu assisto televisão, escuto música, danço...

\section{ONDE?}

De rádio, gosto de Backstreet Boys, Hansom, É o tcham...

TEM ALGUM GRUPO AQUI DA REGIÃO?

Tem não.

Uma fala que difere um pouco é a de T 16, provavelmente por ser morador da zona rural: 
QUANDO NÃO ESTÁ TRABALHANDO, O QUE VOCÊ GOSTA DE FAZER PRA DIVERTIR?

Ah, jogar bola, banhar em represa, piscina... montar em boi.

J 14 mostra um lado típico dos adolescentes entrevistados que é a preocupação com a opinião de outras pessoas:

O QUE VOCE FAZ PARA SE DIVERTIR?

Fico em casa assistindo TV, quase não saio, não gosto muito de sair por causa do preconceito do povo no meio da rua.

\section{QUE TIPO DE PRECONCEITO?}

Sei lá sabe, porque eles implicam com meu namorado. Ai ele é super bacana, mas eu acho que o povo náo gosta dele, quando eu comecei a namorar ele eles falavam que eu estava grávida. $E$ aonde eu passava na rua eles falavam isso, dai eu fico em casa. A gente namora em casa.

VOCE ACHA ESSE COMPORTAMENTO NORMAL OU SEUS AMIGOS COSTUMAM SAIR...?

$A h$, isso vai do adolescente, né? Porque uns gostam de sair se divertir, mas eu prefiro ficar quieta no meu canto, do quê sair pra rua e ouvir os preconceitos, sei lá eles ficam me maltratando, fico mais quieta dentro de casa.

\section{QUANDO ESTÁ EM CASA VOCÉ FICA FAZENDO O QUÉ?}

Fico assistindo TV, quando não tenho que cuidar da minha irmã de um ano. 


\section{$\left.2^{\circ}\right)$ PERCEPÇÕES SOBRE O SERVIÇO: RESISTÊNCIAS E DIFICULDADES}

Entre os tópicos referentes aos serviços citados pelos adolescerites entrevistados, os que mais se repetiram foram a lista de pessoas que aguardam vaga para atendimento e o tempo de espera a cada consulta. Um exemplo é o que diz K 16:

(...) Eu já estava fazendo o tratamento, ai eu sumi o papelzinho e perdi a vaga...

VOCÊ ESTÁ GOSTANDO DO ATENDIMENTO QUE ESTÁ RECEBENDO AQUI?

Ah, é bom, né? Só é ruim por causa que é muita gente e é difícil conseguir vaga.

M 13 já vai um pouco mais além ao apresentar uma possivel solução para o problema:

AQUI NESSA UNIDADE, VOCE ACHA QUE TEM JEITO DE MELHORAR O ATENDIMENTO? COMO?

Acho que sim. Eles podiam aumentar o atendimento, ter mais gente atendendo, aumentar os aparelhos, colocar mais coisas pra ter condições de atender melhor e mais gente.

A fala de $\mathbf{E} 17$ é também no mesmo sentido:

NO ATENDIMENTO QUE É FEITO AQUI, VOCÉ ACHA QUE TEM JEITO DE MELHORAR? 
Falta muitas coisas, falta mais gente pra trabalhar demora pra atender e é dificil pra conseguir vaga, muito dificil mesmo, a gente tem que levantar muito cedo, cedo mesmo. Quando eu fui conseguir essa vaga pra amumar meus dentes eu levantei 4 horas da manhã e eu fiquei até 8 horas da manhã pra conseguir a vaga.

E NO JEITO DO ATENDIMENTO AQUI? DAS AUXILIARES, DOS DENTISTAS, VOCE ACHA QUE TEM ALGUMA COISA PRA MELHORAR?

Não, está tudo bom mesmo.

De modo geral as observações feitas pelos adolescentes a respeito do serviço foram a de que este "é muito bom". Esta referência se repete tanto para o atendimento clínico quanto para as atividades educativas. Mesmo quando provocados sobre estas, mantiveram a postura anterior. No entanto, quase todos já haviam se esquecido dos assuntos tratados. É bom lembrar que todos os entrevistados estavam em tratamento e, para tal, é exigida a presença em 4 palestras. Esta é a norma do serviço. Este pode ser um indicativo que as "palestras" não têm cumprido o papel esperado. Seguem alguns exemplos desse ponto:

L 16:

E DAS PALESTRAS ODONTOLOGICAS QUE VOCÊ JÁ ASSISTIU, O QUE VOCE ACHOU DELAS?

Eu não me lembro de nada não... já faz muito tempo.

G 16, que já foi atendida na Faculdade de Odontologia da UFG:

VOCÊ JÁ PARTICIPOU DAS ATIVIDADES EDUCATIVAS AQUI?

Lá na Faculdade sempre tinha palestra, eu participava das palestras. Porque lá era o professor que ensinava aos alunos, os alunos estavam lá para aprender e os professores ficavam em cima, né? Ai, de acordo com o que ia 
aprendendo, ia subindo mais... lá tinha muitos professores e muitos alunos. Eles faziam todo tipo de tratamento de dente lá...

VOCÊ SE LEMBRA DE ALGUM ASSUNTO QUE FOI TRATADO NESSAS PALESTRAS?

No momento não. Eu já estive em várias palestras lá...

E 16 refere-se a um valor pouco lembrado pelos demais adolescentes que é a vinculação ao profissional ao referir-se a ter "um dentista separado". Ao fazer isso deixa implicita a idéia de que nem sempre isso acontece, o que pode ser apontado como uma dificuldade. Quanto aos assuntos das atividades educativas, ela se lembra do óbvio, fica a indagação se são apenas estes os assuntos tratados:

\section{O QUE VOCÉ ACHOU DO ATENDIMENTO AQUI?}

Achei bom aqui. As pessoas atendem a gente muito bem na hora que a gente vai tratar o dente, as pessoas são excelentes aqui.

\section{VOCÉ PARTICIPOU DE ALGUMA ATIVIDADE EDUCATIVA?}

Participei já. Eles ensinaram como é que a gente escova os dentes. O que a gente deve comer para fortalecer os dentes da gente...

\section{VOCE SE LEMBRA DE MAIS ALGUMA COISA?}

Não só isso, como é que escova, os alimentos que deve comer, o que não deve... só isso.

\section{TEM COMO FICAR MELHOR O ATENDIMENTO AQUI?}

$A h$, não sei... porque pelo menos na hora que eu chego aqui, tudo bem. $\underline{\text { A gente }}$ tem o dentista separado, então pra mim tá bom assim mesmo.

T16 tem uma fala semelhante: 
VOCE JÁ PARTICIPOU DE ALGUMA ATIVIDADE EDUCATIVA, PALESTRAS, VOCE JÁ FOI AQUI? ACHOU O QUÉ? LEMBRA DE ALGUMA COISA?

Já, achei bom, mas não lembro de nada... ah, tem que escovar os dentes três vezes ao dia, não deixar dar cánie, obturar sempre... eu não lembro mais.

Uma fala que se diferencia é a de $\mathbf{J} 14$. Ela parece ter uma experiência negativa com atendimento odontológico em um sentido que vem sendo bastante discutido na saúde de modo geral, particularmente na saúde bucal, que é a tendência de "culpabilizar a vitima" pelos problemas encontrados. É atualmente um ato corriqueiro na odontologia fazer a evidenciação de placa, por exemplo. A este ato se segue usualmente uma explicação do profissional que mostra as áreas mais "sujas", isto é, onde a placa bacteriana está mais densa por "culpa do paciente que não escova direito e não cuida da boca". Isto pode gerar um sentimento de vergonha.

E POR QUE VOCÊ ACHA QUE ISSO [procurar atendimento odontológico] ACONTECE, MESMO TENDO A CHANCE DE TRATAR DE GRAÇA?

Muitas das vezes pode ser até vergonha, né? De abrir a boca...porque na primeira vez que eu vim aqui no CAIS, eu até fiquei com vergonha de abrir a boca, mas a dentista encontrou uma cárie só no meu dente. E depois desse dia mais nunca encontrou, sempre falou que meus dentes são saudáveis e não sei o quê.

\section{VOCÊ GOSTA DAS ATIVIDADES EDUCATIVAS?}

Ah, eu gosto porque... na primeira vez que teve eu não gostei muito não, porque sei lá, essas pessoas que não gostam mesmo de amumar os dentes eu acho que isso é orgulho, muito orgulho. Essas pessoas que penso que só porque é a SUDS ou porque é de graça, tem muito orgulho. Então na primeira vez que fui, eu tinha isso. Então no começo eu não gostei muito, depois eu comecei a achar legal. 
Outro ponto que ela traz é a questão do status de se receber um tratamento gratuito. O SUS, chamado de "a suds" é identificado como sendo um serviço para pessoas de piores condições econômicas e sociais e, portanto, desqualificado. É importante observar que $o$ atendimento recebido no serviço público mudou $o$ preconceito que existia com este tipo de atenção.

\section{$\left.3^{\circ}\right)$ PERCEPÇÕES SOBRE O SERVIÇO: NECESSIDADES E POSSIBILIDADES}

Nesta categoria foram agrupadas as falas que traduzem, na visão dos adolescentes, as necessidades por eles percebidas e as possibilidades que os serviços oferecem a estes jovens, tanto aquelas ações já existentes quanto aquelas hipotéticas, que mostram o que poderia ser desenvolvido na unidade. De modo geral o serviço foi classificado como bom ou "bem feito". Sobre as atividades educativas apresentaram a percepção de que estas são melhores quando realizadas em grupos e desenvolvidas de modo mais dinâmico. Entendem que têm pouca paciência para atividades mais longas e que o lugar de aprender é na escola.

A importância atribuída à escola na aquisição de conhecimentos, indica a validade de um trabalho conjunto, estreitando os relações entre as unidades de saúde e de ensino. C 14:

SE FOSSE FORMADO UM GRUPO DE ADOLESCENTES, AQUI NO CAIS, VOCE PARTICIPARIA, SERIA IMPORTANTE?

Acho que seria importante. 
ONDE QUE O ADOLESCENTE CONVERSA SOBRE ASSUNTOS QUE INTERESSAM A ELE?

Ah, acho que na escola... só nas escolas.

M 12 mostra que as atividades educativas desenvolvidas na sua escola tiveram um efeito positivo nos seus hábitos de higiene bucal. Quanto às atividades vivenciadas no CAIS, o aspecto ressaltado foi o tratamento recebido e a possibilidade de relacionamento interpessoal:

VOCÉ JÁ PARTICIPOU DE ALGUM TRABALHO COM DENTISTAS?

Só lá na escola do estado que eu estudava. Agora que eu estou começando aqui...

NA OUTRA ESCOLA TINHA QUE TIPO DE PROGRAMA?

Na outra tinha escovação, eles ensinavam o jeito de escovar. Tinha dentista pra olhar os dentes.

ISSO ERA DIRETO OU SO DE VEZ EM QUANDO?

De vez em quando. A escovação também era de vez em quando. Tinha tratamento de dente na escola.

VOCÉ ACHA QUE ESTE TRABALHO QUE FOI FEITO LÁ NA ESCOLA FEZ VOCE MUDAR O HÁBITO DE ESCOVAÇÃO, O JEITO DE CUIDAR DOS DENTES?

Fez sim, por causa que eu escovava muito rápido, né? Agora eu estou escovando direitinho, pra gengiva não machucar...

O QUE VOCE ACHOU DO ATENDIMENTO AQUI DOS DENTISTAS DO CAIS? 
Foi bom. Eu achei bom por causa que eles são muito pacientes com a gente, muito educados. Porque tem uns lugares que a gente chega e eles já mandam você deitar, não olham nem seu dente direito, né? Ai você fica com ele doendo de novo, agora esses daqui foi bom. O serviço que eles fizeram ficou legal, eu achei ótimo.

\section{E O TRABALHO EDUCATIVO, DAS PALESTRAS?}

A parte das palestras também foi bom por causa que eles ensinam muito, são muito pacientes com as pessoas também e eu acho bom eles serem desse jeito.

O QUE ELES ENSINAM LÁ É IMPORTANTE? ELES ENSINAM DE UM JEITO LEGAL?

Ensinam de um jeito legal e é tudo muito importante.

O FATO DE FICAR TODO MUNDO JUNTO LÁ NA PALESTRA NÃO ATRAPALHA NÃO?

Não, não atrapalha não. Porque ai você pode se abrir com as pessoas, com o dentista, por isso que é bom.

G 16 também explicita a importância da atuação em diferentes frentes que não apenas a unidade de saúde, que é vista, predominantemente como um local a se recorrer quando se tem doenças:

SE FOSSE PARA TER PALESTRAS SO PARA ADOLESCENTES, SEM CRIANÇAS, COMO É QUE VOCÉ ACHA QUE DEVERIA SER ESSA ATIVIDADE DE EDUCAÇÃO EM ODONTOLOGIA?

É.... assim no modo de explicar para os adolescentes? ...risos... é assim, tem o adolescente que é desligado, que não sabe direito até hoje como escovar os dentes. Tem adolescente que não sabe, tem que explicar melhor pra esses como 
é que escova e não deixar de ir no dentista de seis em seis meses porque dor de dente é triste.

VOCÉ ACHA QUE ADOLESCENTE TEM PACIÉNCIA PRA FICAR OUVINDO PALESTRA SOBRE DENTES E ESSAS COISAS ASSIM?

A maioria não.

ENTÃO COMO É QUE FAZ PARA ENSINAR ESSAS COISAS PARA ELE? Acho que deveria ir na escola. Dar palestras nas escolas, porque trazer adolescentes aqui, eles não vêm não...

NEM SE TIVESSE UMA ATIVIDADE INTERESSANTE...

Não, pode até vir um ou dois, mas a maioria não vem não..

ALÉM DA ESCOLA QUE OUTROS LUGARES PODEM SER TRATADAS ESTAS QUESTÓES DE SAÜDE DO ADOLESCENTE? ONDE ELES SE JUNTAM POR AQUI?

Junta adolescente na igreja, nos... (longa pausa)... adolescentes... igrejas, escolas...

N14 levanta um ponto que, para muitos é encarado com um certo tabu, que é a questão do dinheiro e dos custos do tratamento odontológico:

VOCÊ GOSTA DO ATENDIMENTO AQUI DO CAIS? COMO É QUE É AQUI, O QUE VOCE ACHA DE BOM? POR QUE AQUI E NÃO OUTRO LUGAR?

Porque aqui não precisa pagar é de graça e é muito bom. Porque em outros lugares talvez fazem errado e a gente precisa pagar um dinheirão.

TUDO QUE VOCÉ JÁ PRECISOU AQUI, DE DENTE, VOCÉ TEVE?

Sempre tive. 
É ela também que aponta a possibilidade da participação em ações com adolescentes a serem desenvolvidas no CAIS, ponto esse que se mostrou controverso com alguns dos entrevistados se manifestando favoravelmente e outros contrários a este tipo de atividade. Mas ela mostra a importância dada às relações pessoais estabelecidas nestas oportunidades:

VOCE ACHA QUE OS ADOLESCENTES TÊM PACIÊNCIA DE ASSISTIR ESSAS ATIVIDADES, DE PARTICIPAR..?

Alguns, porque uns ficam assim: "Ah nem...anda logo que eu estou com pressa". Agora outros não, outros prestam bastante atenção.

SE AQUI NO CAIS FOSSE FORMADO UM GRUPO DE ADOLESCENTES PRA DISCUTIR VÁRIOS ASSUNTOS, VOCE ACHA QUE SERIA INTERESSANTE?

Seria. Assim a gente ia conhecer mais coisas, aprender com cada um, seu tipo de ver, seu tipo de fazer...senia bom.

QUE TIPO DE ASSUNTO VOCE ACHA QUE DEVERIA SER ABORDADO NUMA ATIVIDADE DESSA?

O comportamento de um adolescente, isso seria muito bom. Porque alguns são levados, outros são mais timidos, então seria muito melhor assim, todo mundo se abria com todos, falasse alquma coisa boa.

NESSAS ATIVIDADES DE SAÚDE BUCAL PARA ADOLESCENTE, COMO É QUE VOCE ACHA QUE PODERIAM SER ESTAS PALESTRAS?

Tipo uma brincadeira, um filme, alguma coisa assim, uma história ou alguma coisa que deixasse a gente mais confortável... mas por dentro das coisas, pra num ficar aquela chatice: "Ah, eu tenho que ir embora..."

DESSE SERVIÇO ODONTOLOGICO AQUI QUE VOCÊ JÁ CONHECE, VOCE ACHA QUE TEM ALGO QUE PODERIA MELHORAR? COMO? 
Acho que nada, acho que está super bom. Agora eu não sei a opinião dos outros.

\section{$\left.4^{\circ}\right)$ VALORES E INTERESSES}

Aqui foram agrupadas as falas que mostram os valores $e$ interesses que movem os adolescentes entrevistados. O primeiro diz respeito ao consumo, isto é, à forma como eles gastam o dinheiro ou gostariam de gastar, ou ainda como percebem que os demais adolescentes o fazem. Esta se mostrou uma grande preocupação dos entrevistados. A todos foi feita a pergunta: "Porque o adolescente prefere gastar o dinheiro com roupas do que com saúde?" Entre os valores expressos surgem a forte influência do grupo de amigos; a vaidade, que se mostra sem culpa; a capacidade de conquista, quer seja no terreno amoroso ou profissional; o poder e a autonomia recém adquiridos de lidar com o dinheiro da forma que thes agradar; a ousadia associada à liberdade levando a ações inconseqüentes; e 0 valor atribuido à escola e aos pais como fonte de conhecimento e normas de vida.

Seguem-se algumas das respostas recebidas.

\section{12}

Porque ele gosta mais de roupa do que de gastar dinheiro com saúde. Ele quer comprar uma coisa pra ele, não gastar com saúde. A roupa é dele mesmo.

\section{T 16:}

Eu acho comum, porque eles querem andar mais bonitos, arrumar namorada... o modo de vestir influencia. 


\section{N 14:}

$E$, ele só quer fazer isso, jóias...outras coisas deixa pra depois, os pais cuida... o dinheiro é meu, eu faço o que eu quero.

\section{M13:}

Se ele colocar aquele dinheiro na sua boca... então, ele prefere muito mais ir em outro lugar, comprar coisas pra ele. Dinheiro na boca não aparece. Eles podem ir numa pizzania, comprar roupa, um monte de coisa...

\section{J 14:}

A maioria é assim, mas eu não, porque eu estou juntando dinheiro pra colocar aparelho, então eu não posso gastar dinheiro à toa. A maioria gasta com roupa.

A questão da aparência, da beleza foi também trazida à tona em várias oportunidades, inclusive relacionada com o consumo. A fala de $\mathbf{G} \mathbf{1 6}$ traz também o fato de se relacionar os chamados "profissionais da saúde" muito mais com profissionais da doença:

PORQUE OS ADOLESCENTES GASTAM A GRANA COM ROUPAS?

Porque ele quer sempre estar bonito.... é pela beleza.

\section{A BELEZA É MAIS IMPORTANTE do QUE a SAÚdE PARA O ADOLESCENTE?}

Não. É porque a gente só vai no médico quando está doente mesmo.

\section{E NO DENTISTA?}

Eu fui ao dentista quando eu vi uma cárie no meu dente. Ai eu fui na Emergência, ai fiz tratamento lá uns quatro anos, ai todo mês eu ia no dentista, fazia revisão... Ai agora eu vou de seis em seis meses, agora eu vou. 


\section{VOCÉ NÃO É DAQUELAS QUE TÊM MEDO DE IR AO DENTISTA?}

Não, pelo contránio, eu gosto de ir ao dentista...

O medo, que é um fator freqüentemente citado em trabalhos odontológicos como algo muito presente, não foi considerado pelos entrevistados comc algo concreto. Nenhum deles relatou ter medo de dentista ou do tratamento. É evidente que os entrevistados podem ser considerados diferenciados da população em geral por já serem usuários e já terem tido vários contatos com os profissionais da área. Mesmo assim, é um dado relevante para esta pesquisa o não aparecimento do medo, talvez isso possa ser mais um fator positivo ligado à realização das atividades educativas.

Muito significativa também é a fala de E 15 que traduz valores que parecem ser bem típicos nos entrevistados:

\section{QUE ASSUNTOS INTERESSARIAM AOS ADOLESCENTES?}

Eu acho assim que deveriam ensinar, né? A gente só vê jovens morrendo, drogas, um mundo que a gente nem sabe como é que é e já vai enfiando a cara. Deveniam ensinar eles mais por causa da questão das drogas e de ficar nas ruas, porque às vezes a gente vê até meninos, crianças no meio das ruas, soltas. Às vezes elas tem até o lugar de ficar, mas não querem, querem ficar no mundo, cheirando droga com os amigos que dão conselhos errados.

VOCE ACHA ASSIM QUE OS AMIGOS SÃO A GRANDE INFLUÊNCIA DO ADOLESCENTE?

É a grande influência é, são os grupos de amigos que influenciam a cabeça dos adolescentes.

As respostas anteriores e a de $\mathbf{T} 16$, transcrita a seguir, demonstram claramente a preocupação que os adolescentes têm com questões sociais, 
diferenciando suas necessidades pessoais das de outras pessoas, mesmo quando não está bem claro para eles os mecanismos que levam aos problemas.

QUANDO VOCE FOI ATENDIDO AQUI NO CAIS, FOI BOM O ATENDIMENTO, VOCÊ GOSTOU? TEM ALGUMA COISA QUE VOCÊ ACHA QUE DEVE MELHORAR?

Foi, eu gostei. Acho que está bom ainda.

E PARA A REGIÃO, VOCÉ aCHA QUE O ATENDIMENTO DE ODONTOLOGIA ESTÁ BOM OU TEM QUE MELHORAR PARA AS PESSOAS?

Ah tem que melhorar, né?

COMO?

Ah, mudar de prefeito, né? Prefeito colocar mais verba para ter mais dentista, mais doutor pra atender as pessoas mais rápido.

O fato de que não se pode falar de um "adolescente típico", como se todos fossem iguais, compartilhando os mesmos valores e interesses, é traduzido diversas vezes ao longo das entrevistas. Para exemplificar foi escolhida a fala de E 17:

O QUE QUE O ADOLESCENTE GOSTA DE FAZER DE UM MODO GERAL?

Ah, tem muitos que gostam de trabalhar, mas tem uns que gostam de ficar assim mais no canto, ficar mais escondido às vezes gosta de fazer baqunça. Eles caçam a turma deles e ficam ali...logo já estão fazendo coisas que não pode.

COISAS QUE NÃO PODE? QUE TIPO POR EXEMPLO?

Ah, assim...já logo vira fumar maconha, cigarro, beber, igual cair na... cair na vida mesmo assim...desses adolescentes tem muitos. 
POR AQUI NESSA REGIÃO VOCÊ ACHA QUE TEM MUITA DROGA?

Tem, na minha cidade lá...hum...rola muito.

E ASSIM VOCE ACHA QUE SE AQUI NO CAIS TIVESSE ALGUM GRUPO DE ADOLESCENTES PRA ESTUDAR, PRA DISCUTIR OS ASSUNTOS DE ADOLESCENTES VOCE ACHA QUE ELES VIRIAM, PARTICIPARIAM?

Não. Se fosse de obrigação deles vir, eles viriam, mas se não for eles não vem não.

ONDE VOCE ACHA QUE ESSE TIPO DE ENSINAMENTO PARA ADOLESCENTES DEVERIA SER DADO, JÁ QUE AQUI VOCÉ ACHA QUE ELES NÃO VIRIAM?

Na escola, né? Só que ai as mães tem que ficar em cima pra ir.

O assunto drogas surgiu sempre, mesmo quando não perguntado diretamente. No caso de $\mathbf{J} \mathbf{1 4}$, este fato vem associado à violência, que parece estar muito presente em seu cotidiano:

\section{ENTRE OS SEUS AMIGOS TEM ALGUM PROBLEMA DE DROGA?}

Tem, até o meu imão tem isso. Muitas vezes eu até penso que ele não é bom da cabeça. Porque tudo que a gente fala com ele, ele já está avançando pra cima. E toda vez que avança pra cima, ele não dá conta de bater e apanha. Esses dias um menino espancou ele e quase matou ele. Então eu acho que deveriam falar até sobre a violência também e sobre esse negócio de prender as pessoas só depois de 18 anos, eu acho isso muito emado porque uma pessoa de 14 anos, se matar, está com a sua vida livre e espontâneo pra fazer o que quiser, né?

$\mathrm{Na}$ entrevista de $\mathrm{C} 14$ os assuntos predominantes:

O QUÉ VOCE COSTUMA CONVERSAR COM SEUS AMIGOS? 
Esses negócios de drogas, né? Pra amumar esses trem. Vánias coisas, bebidas, namoro.

$\left.5^{\circ}\right)$ SAÚDE BUCAL E A VIDA

Sobre a influência da boca na vida e nas atividades os adolescentes foram questionados diretamente, mas o assunto surgiu também no bojo de outras questões. Muitas vezes a associação mais direta se deu mesmo dentro do esperado aspecto da estética, ou beleza. Também surgiram as questões de relacionamento com outras pessoas e a inserção no mercado de trabalho. Mas um ponto que aparece presente nas respostas de quase todos os adolescentes foi uma surpresa, já que não surge com frequência nem na literatura nem nas falas dos profissionais. Trata-se do mau hálito. Seguem alguns fragmentos das entrevistas que ilustram estes aspectos:

\section{K 16:}

Adolescente chupa balinha pra tirar o mau hálito. Tem prequiça de escovar e o cheiro da pasta de dente é ruim.

\section{G 16:}

VOCE ACHA QUE TER A BOCA BONITA OU NÃO, OS DENTES, TER A BOCA BONITA, ISSO FAZ ALGUMA DIFERENÇA NA VIDA DAS PESSOAS?

Ah, é sempre legal ter os dentes cuidados, dar valor pros dentes, né? Porque quem tem os dentes feios...

O QUE E QUE TEM?

É desvalorizado, desvalorizado. 
VOCE DESVALORIZA UMA PESSOA QUE TEM DENTES FEIOS?

É.. Eu acho horrivel ter os dentes... Tem que estar tudo certinho, limpinho, sem mau hálito.

\section{E 16:}

UMA BOCA SAUDÁVEL INFLUENCIA NA VIDA DAS PESSOAS?

Influencia. Porque a gente fica melhor... Eu mesmo faço esse tratamento de dente há muito tempo, eu acho muito bom. Porque às vezes as pessoas não tem nem condições de fazer o tratamento, que está muito caro e ...nisos... A boca cuidada é muito importante.

\section{UMA BOCA BEM CUIDADA INFLUENCIA EM QUÊ?}

Acho que pra gente mesmo. A gente cuidar da gente mesmo... da boca da gente. Porque às vezes a gente chega para conversar com uma pessoa que a gente nem conhece. Ai depois a gente vira as costas e vai falar assim: "Nossa, aquela menina tá com um mau hálito!" É temivel isso.

\section{T 16:}

E A BOCA NÃO INFLUENCIA NA VIDA DAS PESSOAS?

Influencia também, tem que cuidar de tudo, né?

VOCE NAMORARIA UMA MENINA QUE TEM A BOCA TODA ESTRAGADA?

Não.

VOCÉ CONHECE ALGUÉM QUE TEM A BOCA TODA ESTRAGADA? O QUE VOCE ACHA?

Conheço, é muito feio, né? Muito horrivel.

O QUE VOCÉ ACHA PIOR, ASSIM, NUMA BOCA? 
O fedor, o mau hálito.

ENTÃO SE ESTIVER TODA BANGUELA MAS CHEIROZINHA DÁ PRA ENCARAR?

Ah, até que... ah, não sei não. Ai eu não sei.

\section{N 14:}

DE QUE JEITO VOCE ACHA QUE UMA BOCA, OS DENTES BONITOS, INFLUENCIAM NA VIDA DA PESSOA?

$A h$, porque assim ter um somiso mais bonito, os dentes mais reforcados, fortes, uma boca mais cheirosa, não tem esse problema de qualquer coisa o dente está doendo, apodrecendo, todo furado por causa de cáne...

MAS COMO É QUE ISSO INFLUENCIA? SO NO NAMORO, PRA ARRUMAR NAMORADO?

Não, muda muita coisa, pra você arrumar um emprego os dentes tem que estar assim nos trinques. Acho que eles olham primeiro os dentes. Pra festa, de arrumar namorado, essas coisas de amigo...porque se um amigo da gente tiver assim: "olha lá aquela menina lá está com a boca...eu não dou certo com aquela menina lá não..." Então se for pra falar de mim, se for uma amiga minha que tem uma boca horrorosa, essas coisas...eu acho que muda muita coisa.

\section{14:}

O QUÉ VOCE ACHA PIOR NUMA BOCA?

Mau hálito, dente cariado.

DENTE É IMPORTANTE ENTÃO? VOCÊ ACHA QUE UMA BOCA SAUDÁVEL, BONITA, INFLUENCIA NA VIDA DAS PESSOAS?

Acho sim

COMO? 
Ah, quando você vai beijar uma boca suja assim...dá nojo, muito ruim.

Também fica evidente que a cárie ou outras afeç̧ões bucais não são vistas como doenças. As alterações negativas que podem estar presentes na boca são associadas a sujeira e podridão. A observação tem mostrado que estes são mesmo os termos usados pelos profissionais que desenvolvem atividades educativas com a população, então o que se vê é uma reprodução, tanto por parte dos pacientes, quanto por parte dos profissionais, talvez na busca de utilizar um vocabulário mais próximo daquele identificado como sendo o da população.

\section{12:}

VOCÉ ACHA QUE A BOCA BONITA É IMPORTANTE PRA PESSOA? POR QUE?

É sim, é muito porque se você tiver algum dente cariado, com um dente podre dentro da boca, se chegar perto de uma pessoa você não pode conversar com ela, né? Agora se você tiver a boca limpinha, pode conversar, pode até nir...

\section{VOCE TEM NAMORADO?}

Tenho não...(risos)

VOCE NAMORARIA UM CARA COM OS DENTES CARIADOS? VOCE OLHA PRA ISSO?

Ah, uma pessoa de boca suja...(risos) eu não namorava não...

\section{N14:}

POR QUE VOCE VEM AQUI DE 6 EM 6 MESES? VOCE VALORIZA MESMO, ACHA IMPORTANTE? BOCA É IMPORTANTE?

É muito, porque, nossa senhora, se tiver os dentes todos podres... 
Porque a pessoa olha primeiro nos dentes, né? Assim uma menina bonita que chega assim, ai vai conversar com o rapaz com a boca toda...mal hálito, os dentes podres...claro que ai né...nem pensar. 


\section{CONCLUSÕES}

Ao final deste estudo, é importante ressaltar a pertinência do instrumental metodológico selecionado, pois permitiu atender aos objetivos traçados, criando oportunidade para que os sujeitos pesquisados se expressassem livremente.

Os adolescentes entrevistados mostraram uma preocupação e valorização de sua saúde bucal bem maiores que o esperado pelos profissionais. Isto mostra que a inclusão de novos temas, como saúde bucal, aos usuais sexualidade e drogas, seria muito bem vinda nos programas, já que os interesses dos adolescentes se mostraram bem diversificados.

Os profissionais entrevistados apresentaram uma concepção bem definida do que seja um adolescente. Isto significa que as ações poderiam ser pensadas e desenvolvidas dentro desta forma de conceber. Nesta concepção é apontada a faixa etária como a base de caracterização e esta inclui jovens de 12 a 19 anos, na maioria dos casos. Mas várias outras características também foram apontadas pelos entrevistados como presentes em todos os adolescentes, independentemente de sua idade, sexo ou situação social, econômica e cultural. Estas foram: a grande quantidade de informação sobre várias áreas da vida; imediatismo; intensas mudanças corporais e psicológicas; construção da própria identidade; extrapolação do concreto início da capacidade de lidar com 
abstrações; insegurança e necessidade de serem aceitos tanto pelo próprio grupo como pelos adultos; são críticos; vaidosos; alegres; curiosos e contestadores.

Os maiores entraves apontados pelos profissionais para o desenvolvimento de ações voltadas especificamente para adolescentes são a sua própria formação inadequada e a falta de capacitação e treinamento em serviço com tal propj́sito. Os adolescentes apontam a própria impaciência como fator dificultador para a participação em atividades educativas. Note-se, porém, que estes associaram tais atividades a estratégias consideradas aborrecidas e pouco participativas como as palestras. Esta impaciência também foi apontada como um dificultador para a procura de atendimento clínico já que, para se "conseguir uma vaga" é preciso acordar muito cedo e ficar um longo tempo na fila.

Outro ponto de consenso foi a deficiência numérica de recursos humanos para atenderem à demanda deste grupo, fato agravado pela falta de capacitação relatada.

As atividades relacionadas à atenção clínica não se mostraram problemáticas nem para os profissionais, nem para os adolescentes. No entanto, em relação às atividades educativas, surgiram controvérsias quanto à capacitação profissional para realizá-las, particularmente nas entrevistas dos cirurgiōesdentistas.

Apesar do questionamento surgido por parte dos profissionais quanto à capacitação para a realização das atividades educativas, houve uma coincidência de opiniōes sobre as mais adequadas, que são aquelas mais dinâmicas e participativas. Ou seja, aquelas reconhecidas como mais eficazes pelos profissionais são as mesmas sugeridas pelos adolescentes.

A qualidade do atendimento foi associada pelos adolescentes à forma de tratamento pessoal que os profissionais estabeleceram com eles. As atividades 
educativas em grupo foram identificadas como um fator importante para aproximálos dos profissionais.

Em diversos momentos, nas falas dos profissionais foi possivel identificar que, a despeito da cultura de burocratização e verticalização presentes no serviço estudado, há espaço para a experimentação de inovações, para a criação e a realização pessoal. Curiosamente isto foi relatado em referência aos profissionais que atuam na execução e não no nivel central, na gerência, no planejamento ou em atividades burocráticas de modo geral.

Confirmando estudos anteriores, as atividades educativas são muitas vezes associadas pelos profissionais da saúde, em especial os de saúde bucal, à realização de palestras. Porém a eficácia desta estratégia foi duramente criticada, não sendo considerada adequada para atuação junto a adolescentes, o que não impediu de ser a estratégia mais usada.

Mais uma vez fica evidenciado o isolamento da odontologia dentro da estrutura dos serviços. Não ficou aparente, até o momento desta pesquisa, uma integração com as demais áreas embora a questão da equipe multiprofissional tenha sido colocada como uma necessidade para o desenvolvimento adequado das ações.

Os profissionais entrevistados mostram posições controversas no que diz respeito à inserção do cirurgião-dentista na equipe do Programa de Atenção ao Adolescente. Embora todos sejam favoráveis a esta inserção e às ações multiprofissionais, as expectativas são bem diferentes na medida que vão desde uma "parceria" até uma conexão "com a alma do adolescente" pela proximidade que 0 atendimento profissional propicia. Conceber a participação de diferentes profissionais em uma equipe de trabalho pode significar uma real integração entre as diferentes áreas com ações transdiciplinares ou a mera justaposição de diferentes atividades sem alteração das concepções e formas de intervenção. 
A diminuição da faixa etária de entrada dos jovens na universidade faz com que estes tenham que assumir responsabilidades profissionais com adolescentes sendo eles mesmos recém saídos da adolescência ou ainda apresentarem caracteristicas de adolescentes. Isso é um complicador nas relações interpessoais e na formação acadêmica.

A forma como os serviços são montados "sufocam" os profissionais em atividades mecânicas e repetitivas. Foi constatada ausência de espaços e instrumentos que imprimam uma racionalidade ou possibilitem uma reflexão sobre o fazer na saúde. Isto é, não sobra espaço para o questionamento, a reflexão.

O cotidiano do serviço estudado reproduz um fato da contemporaneidade; pelo acúmulo de tarefas e atribuições assumidas nas diferentes esferas da vida, há uma diminuição do tempo reservado ao planejamento das atividades. Não são criados espaços de convivência, de humanização dos serviços. As relações interpessoais são relegadas a segundo plano.

Pode-se dizer que surgiram indicadores para a determinação de diretrizes norteadoras para um futuro planejamento das ações voltadas para adolescentes. Um deles é a integração entre os diferentes programas e áreas. Outro é o investimento na sensibilização dos profissionais para atuarem junto a este grupo populacional. E um terceiro, que pode ser citado como facilitador de todas as ações, é o investimento nas relações interpessoais dos profissionais.

Contrariando uma noção freqüentemente veiculada, o medo do tratamento dentário ou do cirurgião-dentista não surgiu nos relatos dos adolescentes entrevistados nem dos profissionais. Isto pode ser atribuído ao fato de que esta geração, hoje representada pelos adolescentes sujeitos desta pesquisa, já teve atenção em saúde bucal dentro de novos paradigmas e tecnologias, pelo menos no que se refere à prevenção e a intervenções curativas sem dor. É preciso 
contudo ressaltar que o grupo pesquisado não incluiu os "excluídos" da saúde bucal. Isto possivelmente levaria a respostas diferentes.

A escola foi mencionada pelos adolescentes como sendo uma das principais fontes de informação sobre os cuidados com a saúde bucal. Este espaço que tem sido privilegiado desde o início da programação das ações odontológicas no Brasil, é citado pelos adolescentes, também, como sendo um local de socialização, ou, na sua fala, "um local onde se conversa sobre os assuntos que interessam". Também foi citada a igreja como outra fonte de informação e local de encontro de adolescentes. Isto reforça a importância de ações conjuntas nestes três espaços sociais - os serviços de saúde, a escola e a igreja, para se atingir este grupo populacional.

Os profissionais e os adolescentes concordam quanto a relevância do tema "estética" a ser desenvolvido nas atividades educativas em saúde bucal.

Os problemas oclusais assumiram grande importância para o grupo pesquisado, o que veio a confirmar os estudos relativos ao tema já publicados. Nas falas dos adolescentes isto torna-se motivo de grande preocupação pelo fator estético, mas também pela questão financeira.

Um dos resultados que não havia sido cogitado quando do delineamento desta pesquisa foi o fato dos adolescentes não reconhecerem a existência de "doenças bucais" e, sim identificarem como um problema bucal de grande relevância o "mau hálito".

Outro aspecto consensual entre profissionais e adolescentes foi a necessidade da criação de espaços de lazer para este grupo populacional. Estes são ditos ausentes em uma região da cidade que se propõe ao desenvolvimento de ambientes saudáveis, ou espaços que favoreçam a qualidade de vida. 
Nenhum dos profissionais entrevistados utilizou o referencial ou mesmo citou o termo Promoção da Saúde, ainda que a unidade estudada seja o local privilegiado pelo Grupo Gestor do PROLESTE para sua atuação. Evidencia-se, então, que esta concepção do fazer em Saúde Pública, que tem sido largamente difundida no Brasil a partir da década de 90 , ainda não foi incorporada no discurso dos entrevistados e, o que é mais importante, no cotidiano do serviço. Para a incorporação dos referenciais da promoção da saúde seria necessária uma intervenção desde a formação acadêmica de modo a atingir os profissionais em formação, até uma capacitação em serviço, que incluisse as bases conceituais e as estratégias de ação propostas, e que atingisse as diferentes categorias que atuam no setor saúde e fora dele.

A partir desta pesquisa pode ser identificada a predisposição por parte dos profissionais em atuar junto a adolescentes, sendo as dificuldades relatadas associadas a falta de qualificação e, portanto, superáveis.

Finalmente, pode-se concluir que este trabalho aponta para a necessidade de realização de novos estudos relacionados aos adolescentes que abordem suas necessidades, não só epidemiológicas, mas também as principais percebidas; a promoção da saúde de modo amplo e, mais especificamente, o papel da saúde bucal neste campo; as atividades ou estratégias educativas adequadas, e, citando assuntos de maior especificidade odontológica, as questões de oclusão, estética, dor e halitose, voltadas diretamente para os adolescentes. 


\section{8 - REFERÊNCIAS BIBLIOGRÁFICAS}

1. Almeida Jr., J.B. O estudo como forma de pesquisa. In CARVALHO, M.C.M. (org.) Metodologia científica: fundamentos e técnicas. Campinas, Papirus, 1995.

2. Andrade, M.T.S. As representações do cirurgião-dentista do serviço público municipal sobre a prevenção da cárie e seu papel neste processo. São Paulo; 1997. [Dissertação de Mestrado, Faculdade de Saúde Pública - USP] .

3. Ayres, J.R.C.M. e França JR.,I. Saúde do adolescente. In: SCHRAIBER, L.B.; Nemes, M.I.B. e Mendes-Gonçalves, R.B. (Orgs.). Saúde do adulto: programas e ações na unidade básica. São Paulo, HUCITEC, 1996.

4. Ayres, J.R.C.M. Vulnerabilidade e avaliação de ações preventivas. São Paulo, Casa de Edição, 1996.

5. Baldisseroto, J. et al. Prevalência de cárie dental e má-oclusão em escolares em área de abrangência do serviço de saúde comunitária. Mom. \& Perspec. - Porto Alegre. 1996; 9 (2): 103-5.

6. Bellini, H.T. Ensaio sobre programas de saúde bucal. Biblioteca Científica ABOPREV. 1991; 3:2-7.

7. Brasil. Ministério da Saúde. Projeto Promoção da Saúde. Brasilia Ministério da Saúde, 2001. 
8. Brasil. Ministério Da Saúde. Levantamento epidemiológico em saúde bucal: Brasil, zona urbana. Brasilia, Divisão Nacional de Saúde Bucal / FSESP, 1988.

9. Candeias, N.M.F. Conceitos de educação e de promoção em saúde: mudanças individuais e mudanças organizacionais. Rev. Saúde Pública. 1997; 31 (2): 209-13.

10. Cavalcantti, RC. Adolescência. In: Vitiello, $\mathrm{N}$ et al. Adolescência hoje. São Paulo, Roca, 1988.

11. Chaves, M. M. Odontologia social. 2a. ed. São Paulo, Ed. Santos, 1977.

12. Chubb,NH et al. Adolescent self-esteem and locus of control: a longitudinal study of gender and age differences. Adolescence. 1997;32 (125):113-29.

13. Cordon, J. Estudos sobre a força de trabalho em saúde bucal: características do cirurgião dentista no Distrito Federal. Divulg. Saúde Debate. 1991; 6: 19-26.

14. Cordon-Portillo, J., Paes, AMC. Autopercepção de qualidade de vida relativa à saúde bucal. Revista Brasileira de Odontologia em Saúde Coletiva. 2000;1(1):75-88.

15. Cruz Neto, O O trabalho de campo como descoberta e criação. In: Minayo, M.C.S. Pesquisa social: teoria, método e criatividade. Petrópolis, Vozes, 1994.

16. Cury, J. Nova análise do teor de flúor das águas de abastecimento de Goiânia. J. Assoc. Bras. Odontol. -GO. 1996: 34:11.

17. Dini, E.L.; Foschini, A.L.R. e Brandão, I.M.G. Periodontal conditions in a 7-19 year-old student population in Araraquara, São Paulo, Brazil, 1995. Cad. Saúde Públ. 1997; 13(2): 321-4.

18. Domingues, C.M.A.S. Identidade e sexualidade no discurso adolescente. São Paulo, 1997. [Dissertação de Mestrado, Faculdade de Saúde Pública - USP] 
19. Elias, MS. A importância da saúde bucal para adolescentes de diferentes estratos sociais do municipio de Riberão Preto. Riberão Preto-SP;2000 [Dissertação de Mestrado - Escola de Enfermagem de Riberão Preto - USP].

20. Frazão, P. Epidemiologia da oclusão dentária na infância e os sistemas de saúde. São Paulo; 1999. [Tese de Doutorado - Faculciade de Saúde Pública da Universidade de São Paulo].

21. Frazão, P.; Narvai, P.C. e Castellanos, R.A. Prevalência de oclusopatias nas dentições decídua e permanente de crianças na cidade de São Paulo, 1996. São Paulo, 1998. [Trabalho apresentado no curso de Epidemiologia e Saúde Bucal Coletiva da Faculdade de Saúde Pública - USP dentro do VI Programa de Verão do Departamento de Epidemiologia]

22. Freire, M.C.M. et al. Prevalência de cárie e necessidade de tratamento em escolares de 06 a 12 anos da rede pública de Goiânia - GO, Brasil, 1994. Goiânia, 1995. [Trabalho apresentado ao Dep. de Odontologia Social / Faculdade de Odontologia da Univ. Federal de Goiás].

23. Fundação Instituto Brasileiro De Geografia E Estatística. Censo demográfico - 1991, Rio de Janeiro, 1994.

24. Garcia, M. L. e Cutress, T.W. A national survey of periodontal treatment needs of adults in Philippines. Community Dent Oral Epidemiol 1986; 14: 313-6.

25. Gil, A.C. Métodos e técnicas de pesquisa social. São Paulo, Ed. Atlas, 1994.

26. Hagquist, C. e Starrin, B. Health education in schools - from information to empowerment models. Health Promotion International.1997;12 (3):225-32.

27. Haguette, T.M.F. Metodologias qualitativas na sociologia. Petrópolis - RJ, Vozes, 1987. 
28. Kawachi, I. et al. Social capital, income inequality and mortality. Am. J. Public Health, 87 (9): 1491-8, sep., 1997.

29. Laurel, A.C. La política de salud en el contexto de las politicas sociales. IV Congresso Latinoamericano de Ciencias Sociales y Medicina, Cocoyoc - México; 1997 [mimeo].

30. Marcelo, V. C. Avaliação em odontologia: um instrumento no processo educativo da equipe de trabalho. São Paulo, 1997. [Dissertação de Mestrado - Faculdade de Saúde Pública da USP]

31. Minayo, M.C.S. O desafio do conhecimento - pesquisa qualitativa em saúde. São Paulo - Rio de Janeiro, HUCITEC - ABRASCO, 1994.

32. Ministério Da Saúde. Promoção da Saúde: Carta de Ottawa, Declaração de Adelaide, Sundsvall e Santa Fé de Bogotá. Brasilia, 1996

33. Ministério Da Saúde. Secretaria Nacional de Programas Especiais de saúde - Divisão Nacional de Saúde Materno-Infantil. Programa Saúde do Adolescente: bases programáticas. Brasília, 1989.

34. Murray, J.J. Bases para a prevenção de doenças bucais. São Paulo, Ed. Santos, 1992 [Organização Mundial da Saúde]

35. Nadanovsky, P. Redução da cárie depende mais de fatores indiretos do que de tratamento clínico. Boletim Informativo - Rede CEDROS. 1994 $5: 16$.

36. Narvai, P.C. Está ocorrendo um declínio de cárie no Brasil? Jornal da ABOPREV. 1996 7: 12.

37. Narvai, P.C. Odontologia e saúde bucal coletiva., São Paulo, Hucitec, 1994

38. Neder, C. e Manfredini, M. Sorrindo com saúde. Jornal do Conselho Federal de Odontologia. 1997; jun.

39. Nofre, M.A. et al. Prevalência de câncer bucal no serviço de medicina bucal da Faculdade de Odontologia de Araraquara/ UNESP: 1989-1995. RGO. 1997; 45 (2):101-4. 
40. Nordblad, A. et al. Periodontal treatment needs in populations under 20 years of age in Espoo, Finland and Chiangmai, Thailand. Community Dent Oral Epidemiol. 1986; 14: 129-31.

41. Organização Mundial da Saúde. Levantamento epidemiológico básico de saúde bucal: manual de instruções - terceira edição. São Paulo; Ed. Santos; 1991.

42. Organização Mundial da Saúde - Declaração de Jacarta sobre promoção da saúde no século XXI. Jacarta, Indonésia, julho de 1997.

43. Organização Mundial de Saúde. Dia mundial da saúde 1994 : cartela de informação, Genebra, Unidade de Saúde Bucal, abr. 1994.

44. Organizacion Mundial de La Salud / Ministerio de La Salud y Bienestar Social - Canada. Carta de Ottawa para la promoción de la salud, 1986.

45. Organizacion Panamericana de La Salud / Ministerio de La Salud de Colombia. Promocion de la salud y equidad. Bogotá, 1992.

46. Organización Panamericana de La Salud. División de Promoción y Protección de la Salud. Manual para la Educación en Salud Integral Del Adolescente. 1996.

47. Pádua, E.M.M. A coleta de dados. In: Carvalho, M.C.M. Construindo o saber - Metodologia científica: fundamentos e técnicas. Campinas, SP, Papirus, 1995.

48. Paiva, EMM. Avaliação das condições periodontais em adolescentes utilizando parâmetros clínicos em relação ao teste enzimático BANA. Goiânia; 1998 [Dissertação de Mestrado - Instituto de Patologia Tropical - Universidade Federal de Goiás].

49. Peres, F. Adolescência: em busca dos sujeitos sociais. São Paulo, 1995. [Tese de Doutorado, Faculdade de Saúde Pública - USP.]

50. Pinto, V.G. Índice de cárie no Brasil e no mundo. RGO. 1996; 44 (1): $8-12$. 
51. Pinto, V.G. Epidemiologia das doenças bucais no Brasil. In: KRIGER, L. (org) Promoção de Saúde Bucal. ABOPREV- Artes Médicas, 1997.

52. Pinto, V.G. Relacionamento entre padrões de doença e serviços de atenção odontológica. Rev. Saúde Pública. 1989; 23:509-14.

53. Pinto, V.G. Saúde bucal : odontologia social e preventiva. 1a. ed. São Paulo, Ed. Santos, 1989a.

54. Pinto, V.G. Saúde bucal: panorama internacional. Ministério da Saúde/ Divisão Nacional de Saúde Bucal, Brasilia, 1990.

55. Pinto,VG. Atenção em saúde oral e implicações para o futuro na América Latina. 1995 Actual. Odontológica. 12 (39):12-21.

56. Quivy, R. e Campenhoudt, L.V. Manual de investigação em ciências sociais. Lisboa, Gradiva, 1992.

57. Reis, A.O.A. e Zioni, F. O lugar do feminino na construção do conceito de adolescência. Rev. Saúde Pública. 1993; 27(6):472-7.

58. Rocha, D.G. Análise do componente educativo nos programas preventivos em saúde bucal no Brasil, 1980-1994. São Paulo, 1997 [Dissertação de Mestrado, Faculdade de Saúde Pública - USP].

59. Rocha, D.G. e Bicudo Pereira, I.M.T. Educação em saúde bucal: uma experiência com escolares. Rev. Bras. Saúde Esc. 1994; 3(1/4):126-29.

60. Rudio, F.V. Introdução ao projeto de pesquisa científica. Petrópolis, Vozes, 1989.

61. Severino, A.J. Metodologia do trabalho científico, São Paulo, Cortez, 1986.

62. Tones, $\mathrm{K}$. The anatomy and ideology of health promotion: empowerment in context. In Scriven, A. e Orme, J. (orgs.) Health promotion: professional perspectives. London, Macmillan Press, 1996.

63. Tumang, A.J. et al. Aspectos epidemiológicos de saúde bucal em uma população urbana, nas faixas etárias acima de 15 anos. Rev. Odonto Ciência. 1996; 22 (2): 21-31.

64. Universidade de São Paulo. Faculdade de Saúde Pública. Núcleo de 
Estudos e Pesquisas de Sistemas de Saúde. Secretaria de Estado da Saúde de São Paulo. Levantamento epidemiológico da cárie dentária, oclusopatias e fluorose dentária em crianças de 5 a 12 anos de idade, em escolas públicas e privadas do município de São Paulo, em 1996. São Paulo, 1997 [Relatório Técnico]

65. Universidade Federal de Goiás/ Secretaria Municipal de Saúde de Goiânia-GO PROLESTE - Promoção da saúde no distrito sanitário leste - Relatório Técnico. Goiânia, 1999.

66. Vasconcelos, E.M. Educação popular nos serviços de saúde. $3^{\mathrm{a}}$ ed., São Paulo, HUCITEC, 1997.

67. Vignarajah, S. Periodontal treatment needs in 12 and $15-19$ year old school children in the Caribbean island of Antigua, 1990. J Periodont Res. 1994; 29: 324-7.

68. Walter, L.R.F. Avaliação do programa de odontologia para bebês do municipio de Cambé - controle e prevenção da cárie dentária nos 30 primeiros meses. Saúde em Debate. 1991; 32: 75-6.

69. Weare, K. The contribution of education to health promotion. IN: Bunton, R. e Macdonald, G. Health promotion: disciplines and diversity. London-New York, Routledge, 1993. 


\section{ANEXO 1:}

\section{ROTEIRO DE ENTREVISTA PARA OS ADOLESCENTES}

\section{PARTE 1 - Dados Gerais do Entrovistado:}

1. Idade: .....anos

2. Sexo: $\square$ masc. $\square$ fem.

3. Estuda? $\square \operatorname{sim} \square$ não 4. Série: ......... 5. Período: $\square$ manhã $\square$ tarde $\square$ noite

6. Trabalha? $\square \operatorname{sim} \square$ não 7.Tipo de trabalho ou função?

8. Última vez que foi ao dentista? $\square$ menos de um ano $\square$ mais de um ano

9. Qual o tipo de serviço odontológico (dentista) você utilizou?

$\square$ unidade de saúde (posto, centro de saúde etc.) $\square$ da própria escola $\square$ consultório particular $\square$ convênio. Qual?

[outros:

\section{PARTE 2 -}

1. Quando você não está estudando ou trabalhando quais são suas atividades preferidas (lazer, diversão)?

2. Alguns adolescentes preferem gastar seu dinheiro mais com roupas de marcas caras do que com cuidados com saúde, por que você acha que isso acontece ?

3. Dentes e boca saudáveis e bonitos influenciam na vida das pessoas? De que forma?

4. A maioria das pessoas já sabe o que fazer e que tipo de cuidados deve ter para promover e manter sua saúde mas, mesmo assim, não fazem. Na sua opinião por que isso acontece?

5. O que você acha dos serviços odontológicos desta unidade? De que forma eles poderiam ser melhorados?

6. Você se lembra de ter recebido informações ou instruções sobre saúde bucal? De quem? Que assuntos foram abordados? 


\section{ANEXO 2 \\ ROTEIRO DE ENTREVISTA PARA OS FUNCIONÁRIOS:}

\section{PARTE 1 - Dados Gerais do Entrevistado:}

1. Função que exerce: Há quanto tempo?

2. Desenvolve alguma atividade relacionada a adolescentes? Qual (is)?

PARTE 2 -

1. Conhece alguma atividade da Secretaria voltada para adolescentes?

2. Você gosta (gostaria) de desenvolver atividades com adolescentes? Por que?

3. Você identifica resistência por parte dos funcionários de trabalhar com adolescentes? Que tipo? Por que elas surgem?

4. Você conhece algum trabalho educativo desenvolvido com adolescentes aqui? Como você avalia este trabalho? Vê alguma forma de melhorá-lo?

5. Como é a receptividade dos adolescentes a este trabalho?

6. Que tipo de atividades são (seriam) interessantes de desenvolver com adolescentes? Por que?

7. Você pensa que os serviços, da forma que estão estruturados, têm papel importante na vida das pessoas? De que modo? Até que ponto?

8. Como você descreveria (caracteristicas) os adolescentes que procuram a unidade (o serviço)?

9. Você acha que eles estão satisfeitos com a atenção recebida aqui? Por que? 